\title{
INFLUÊNCIA DO AVALIADOR NO RESULTADO DA CLASSIFICAÇÃO DE TERRAS EM CAPACIDADE DE USO
}

\section{DANIELE FoCHT}

Engenheiro Agrônomo

Orientador: Prof. Dr. GERD SPAROVEK

Dissertação apresentada à Escola Superior de Agricultura

"Luiz de Queiroz", Universidade de São Paulo, para obtenção do título de Mestre em Agronomia, Área de Concentração: Solos e Nutrição de Plantas.

PIRACICABA

Estado de São Paulo - Brasil

Dezembro - $1998^{\circ}$ 
FOCHT, Daniele. Influência do avaliador no resultado da classificação de terras em capacidade de uso. Piracicaba, Dissertação (Mestrado) Escola Superior de Agricultura "Luiz de Queiroz", Universidade de São Paulo. 1998. 79 p.

\section{ERRATA \& CORRIGENDA N. 1}

$\begin{array}{lllll}\begin{array}{l}\text { p. } \\ 29\end{array} & \begin{array}{l}\text { item } \\ 3.1 .4\end{array} & \begin{array}{l}\text { linha } \\ 25\end{array} & \begin{array}{l}\text { onde se lê } \\ \text { Destas, para a realização da } \\ \text { classificação. }\end{array} & \begin{array}{l}\text { leia-se } \\ \text { (eliminar período) }\end{array} \\ 30 & 3.1 .4 & 3 & \text { Tabela } 5 & \text { Tabela 3 } \\ 32 & 3.2 .2 .1 & 21 & \text { (Tabela 3) } & \text { (Tabela 4) } \\ 46 & 4.2 .2 & 8 & \begin{array}{l}\text { Para estes as classes VI } \\ \text { e VII... }\end{array} & \begin{array}{l}\text { Para estes as classes IV } \\ \text { e VII... }\end{array} \\ & & & & \text { boas }\end{array}$




\section{Dados Internacionais de Catalogaçāo na Publicação (ClP) DIVISĀO DE BIBLIOTECA E DOCUMENTAÇĀO - Campus "Luiz de Queiroz"/USP}

\section{Focht, Daniele}

Influência do avaliador no resultado da classificação de terras em capacidade de uso / Daniele Focht. - - Piracicaba, 1998.

79 p. : il.

Dissertação (mestrado) - Escola Superior de Agricultura Luiz de Queiroz, 1998.

Bibliografia.

1. Assentamento rural 2. Avaliação de terras 3. Classificação do solo 4.

Geoprocessamento 5. Levantamento do solo 6. Microbacia Hidrográfica do Córrego do Ceveiro 7. Sensoriamento remoto 8. Sistema de Informação Geográfica 9. Uso da terra 10. Valorização I. Título 


\title{
INFLUÊNCIA DO AVALIADOR NO RESULTADO DA CLASSIFICAÇÃO DE TERRAS EM CAPACIDADE DE USO
}

\author{
DANIELE FOCHT
}

Aprovada em:...........................

Comissão julgadora:

Prof. Dr. Gerd Sparovek

ESALQ/USP

Prof. Dr. Carlos Alberto Vettorazzi ESALQ/USP

Dra. Sonia Carmela Fauci Dechen IAC 
"O corpo é coisa encantada que precisa mais do que comida e bebida para viver. Ele precisa de palavras porque é nelas que mora a esperança."

Rubem Alves

Aos meus pais, Ewgenij e Jurema, que tanto amo...

Sem o amor e o apoio de vocês em todas as minhas decisões, eu não estaria aqui hoje... 


\section{AGRADECIMENTOS}

Ao meu orientador Prof. Gerd Sparovek, pela orientação no transcorrer do presente trabalho que, sem dúvida só engrandeceu a minha vida profissional.

A CAPES pelo auxílio financeiro nesses dois anos de mestrado.

Aos professores e funcionários do Departamento de Ciência do Solo que participaram da minha convivência diária.

Aos professores Geraldo Victorino de França, Francisco Antonio Monteiro e Carlos Alberto Vettorazzi, por todo o carinho e tempo despendidos comigo.

Aos companheiros de pós-graduação pela amizade e confiança.

A minha turminha revolucionária Carlinhos, Rodrigo, Marcão, Simone e Marchiori. Como tenho saudades das nossas reuniões...

A minha turma da "sala do Gerd" Simone, Enio, Mara e Beta, e aos freqüentadores mais assíduos Miguel, Rodrigo, Robinson, Peterson e ao nosso caçula Allan, cujas participações diárias em minha vida só tiveram como abrilhantar o meu trabalho.

A galera da minha casa que sempre vai ser um "albergue" Luciana e Márcia com as quais convivi na minha vinda para Piracicaba e Nivea, nossa caloura, só tenho a agradecer a amizade, o carinho, os conflitos, enfim a convivência que me fizeram crescer como pessoa. Aos nossos amigos mais chegados Glauco, Beto, Marcelo Nascimento e Caco, só posso agradecer o privilégio de sermos amigos.

Aos amigos inesqueciveis Rodrigo, Enio, Marcelo e Hamilton que me forneceram tanta ajuda em momentos difíceis, estando sempre presentes com seus ombros amigos, dispostos a me causar momentos de muitas risadas e até mesmo puxões de orelha que foram tão importantes, não tenho palavras para agradecer.

Ao meu grande amigo Glaucio Roloff cuja confiança depositada em mim, trouxe-me até aqui.

A Deus pela minha vida, pelas minhas conquistas e por ter colocado cada pessoa aqui citada ou não, em meu caminho... 


\section{SUMÁRIO}

Páginas

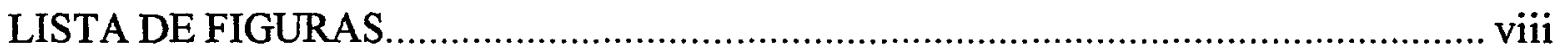

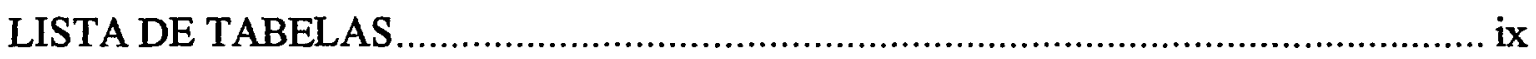

RESUMO

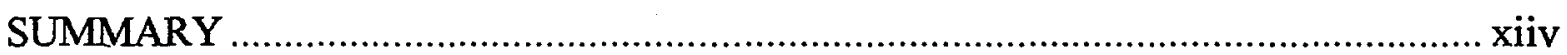

1 INTRODUÇÃO

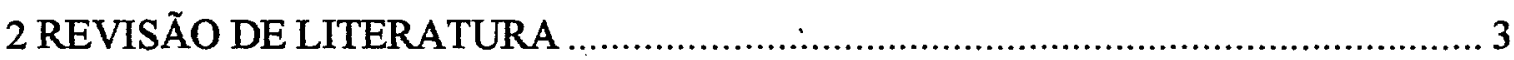

2.1 Microbacia hidrográfica como unidade de estudo.................................................. 3

2.2 Sistemas para a determinação da potencialidade das terras ........................................ 4

2.3 Sistema de Classificação da Capacidade de Uso das Terras (SCCUT) ........................ 6

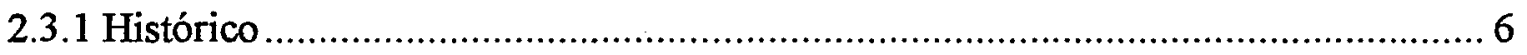

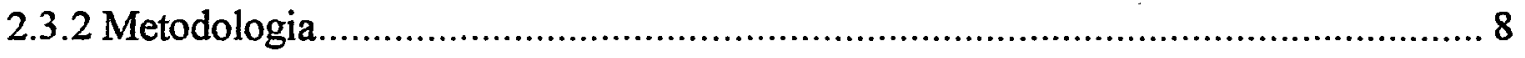

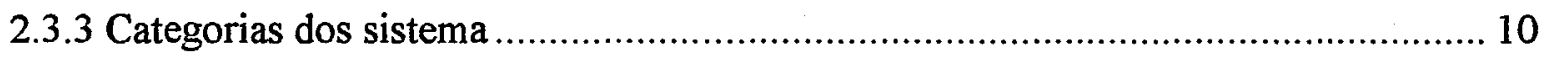

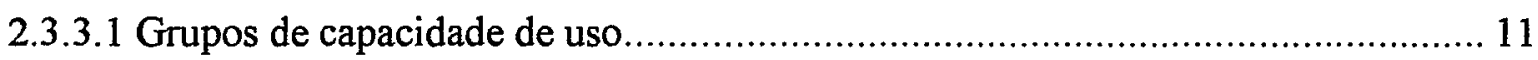

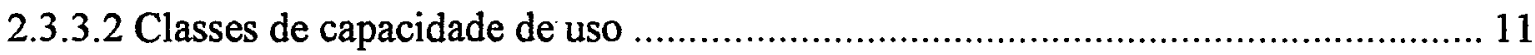

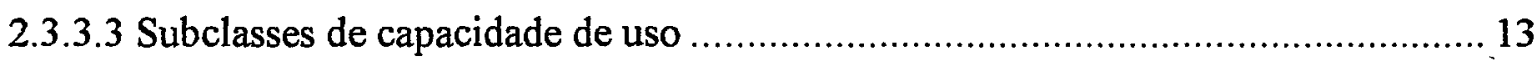

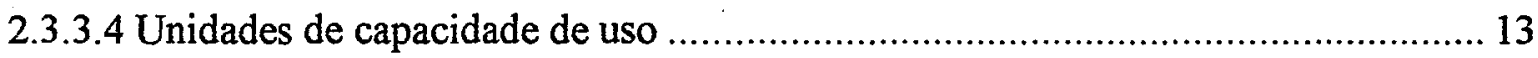

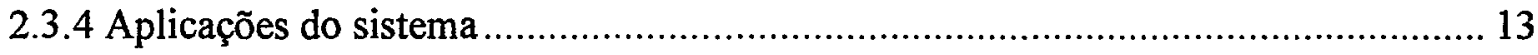

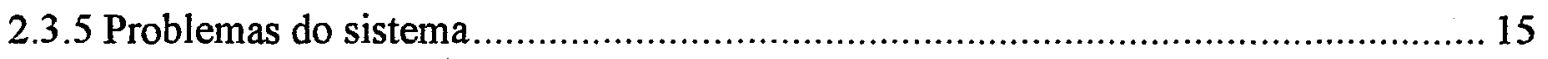

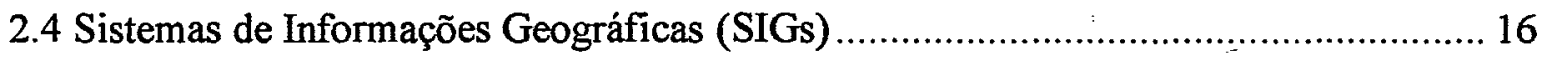

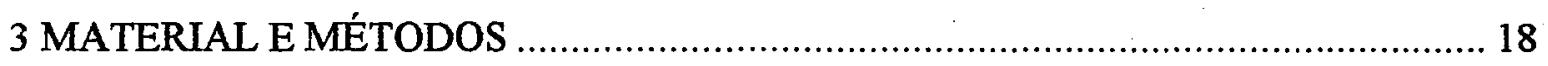

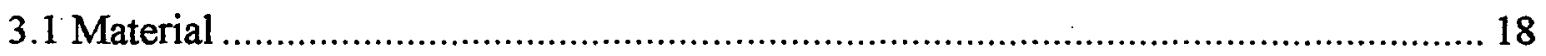




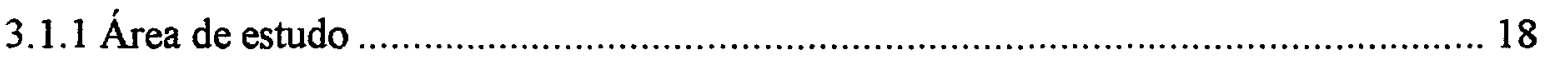

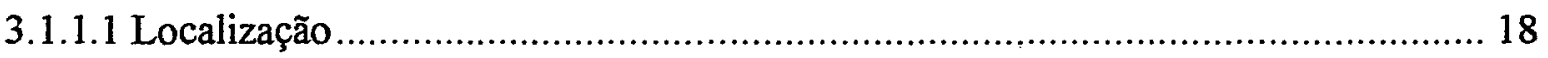

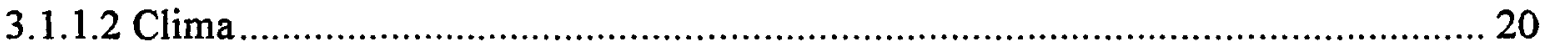

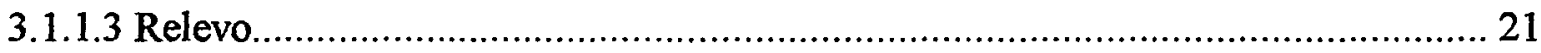

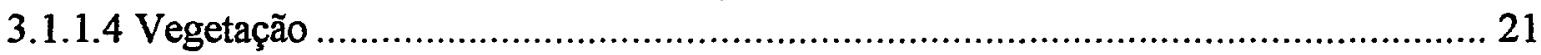

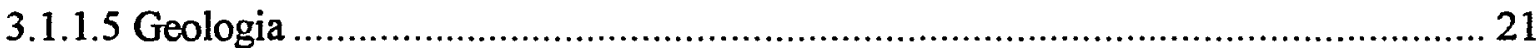

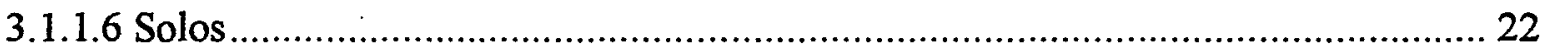

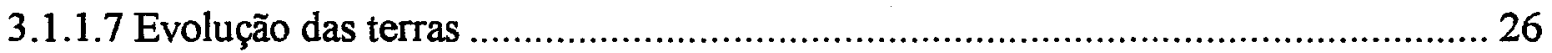

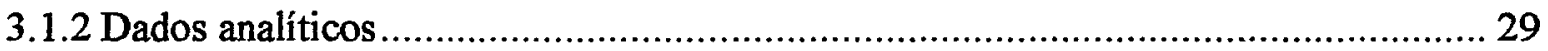

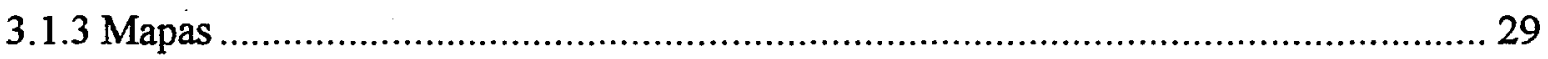

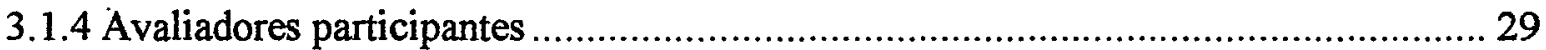

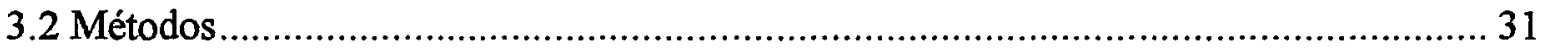

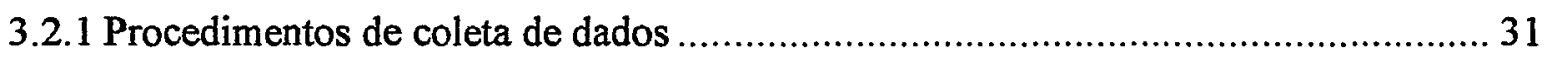

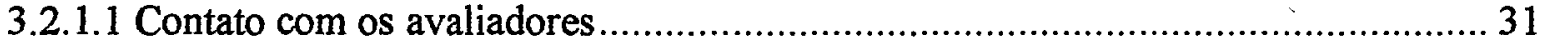

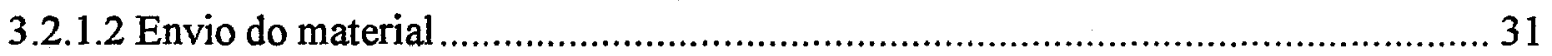

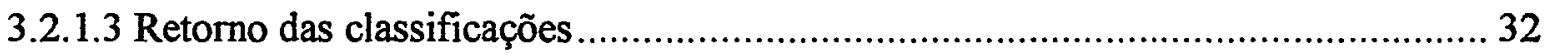

3.2.2 Análise das classificações da capacidade de uso das terras ................................... 32

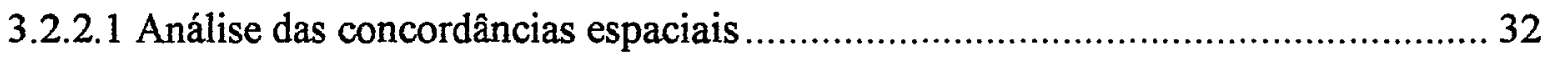

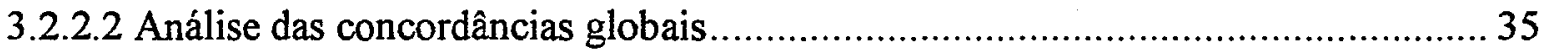

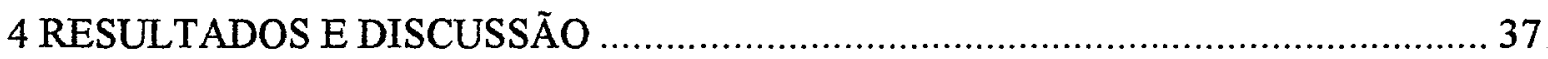

4.1 Decisão sobre o material necessário para a classificação …....................................... 37

4.1.1 Observação dos avaliadores quanto ao material enviado..........................................38

4.2 Classificações da capacidade de uso das terras ........................................................... 43

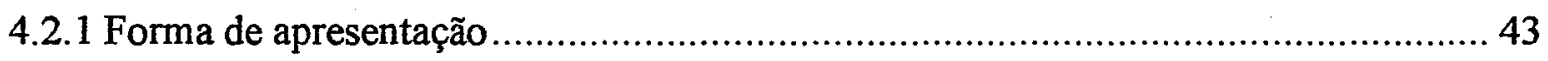

4.2.2 Mapas de classificação da capacidade de uso das terras ......................................... 44

4.3 Análise de concordância entre as diferentes classificações ........................................ 52

4.3.1 Concordância das classificações em função do avaliador......................................... 52

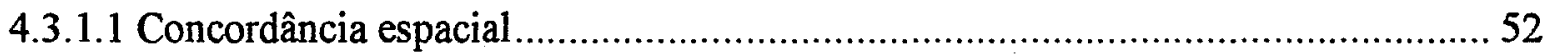




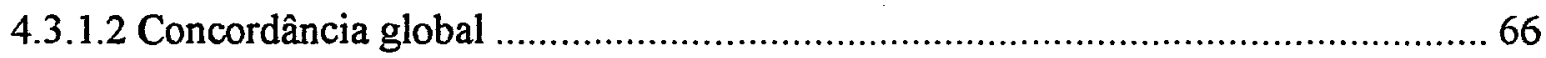

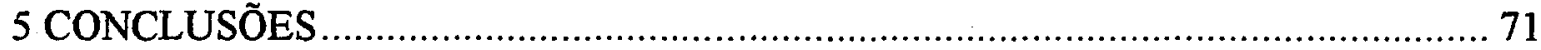

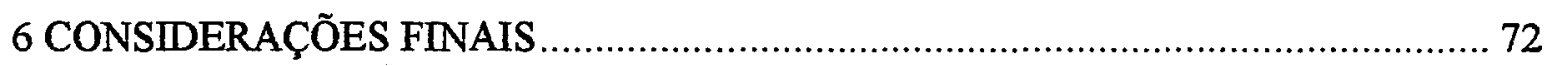

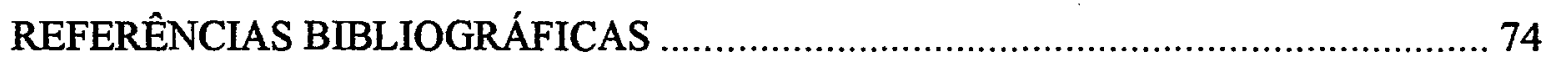




\section{LISTA DE FIGURAS}

Página

1 Esquema das categorias do SCCUT (Lepsch et al., 1991) ........................................ 10

2 Localização da área de captação na Microbacia Hidrográfica do Córrego do

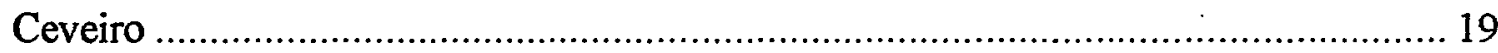

3 Mapa de solos da Microbacia Hidrográfica do Córrego do Ceveiro ............................. 25

4 Mapa de uso das terras da Microbacia Hidrográfica do Córrego do Ceveiro, em 1995 28

5a Mapa de classes de declividade gerado pelo SIG Idrisi ........................................... 41

5 b Mapa de classes de declividade gerado manualmente........................................... 42

6 Mapa de classificação da capacidade de uso das terras do avaliador 1 ......................... 47

7 Mapa de classificação da capacidade de uso das terras do avaliador 4 .......................... 48

8 Mapa de classificação da capacidade de uso das terras do avaliador 2 ......................... 49

9 Mapa de classificação da capacidade de uso das terras do avaliador 3 ........................ 50

10 Mapa de classificação da capacidade de uso das terras do avaliador 5 ...................... 51 


\section{LISTA DE TABELAS}

Página

1 Dados climatológicos do município de Piracicaba (média de dez anos) ........................ 20

2 Dimensão das áreas de uso das terras da Microbacia Hidrográfica do Córrego

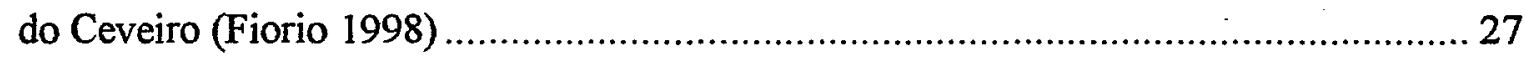

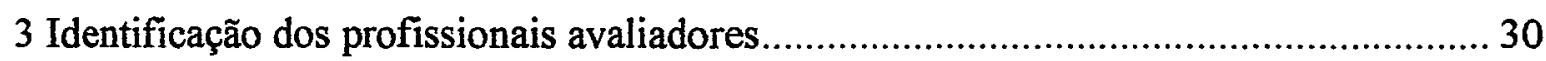

4 Exemplo da disposição dos dados em uma matriz de erros ......................................... 33

5 Qualidade do parâmetro Kappa (k), segundo sua faixa de concordância

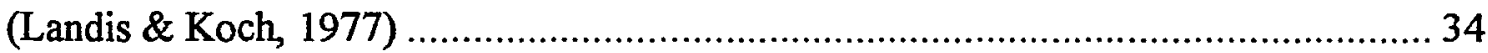

6 Qualidade do parâmetro Kappa (k), segundo sua faixa de concordância para a

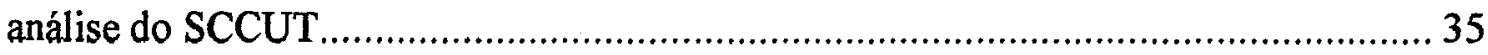

7 Solicitações de material para a classificação das terras da Microbacia Hidrográfica do Córrego do Ceveiro em classes capacidade de uso ............................38

8 Matriz de erros da relação entre as áreas dos mapas de classes de declividade gerado manualmente e pelo Idrisi ...................................................................... 40

9 Forma de apresentação das classificações de capacidade de uso das terras ................... 44

10 Áreas das classificações da capacidade de uso das terras segundo os cinco primeiros avaliadores

11 Matriz de erros com as áreas da relação entre a classificação da capacidade de uso das terras dos avaliadores 1 e 2 .

12 Matriz de erros com as áreas da relação entre a classificação da capacidade de uso das terras dos avaliadores 1 e 3 .

13 Matriz de erros com as áreas da relação entre a classificação da capacidade de uso das terras dos avaliadores 1 e 4 . 
14 Matriz de erros com as áreas da relação entre a classificação da capacidade

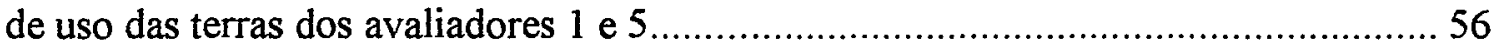

15 Matriz de erros com as áreas da relação entre a classificação da capacidade

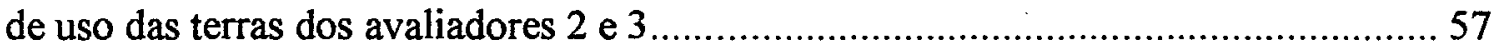

16 Matriz de erros com as áreas da relação entre a classificação da capacidade

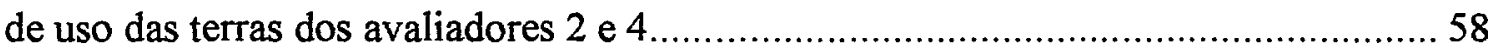

17 Matriz de erros com as áreas da relação entre a classificação da capacidade de uso das terras dos avaliadores 2 e 5 . 59

18 Matriz de erros com as áreas da relação entre a classificação da capacidade de uso das terras dos avaliadores 3 e 4 .

19 Matriz de erros com as áreas da relação entre a classificação da capacidade de uso das terras dos avaliadores 2 e 5

20 Matriz de erros com as áreas da relação entre a classificação da capacidade de uso das terras dos avaliadores 4 e 5 . 62

21 Parâmetro $\mathrm{k}$ e qualidade de concordância para as concordâncias espaciais entre as classificações 65

22 Áreas e estatística das classificações da capacidade de uso das terras de todos os avaliadores 67

23 Áreas e estatística das classes de capacidade de uso das terras não utilizadas por todos os avaliadores 69 


\section{INFLUÊNCIA DO AVALIADOR NO RESULTADO DA CLASSIFICAÇÃO DE TERRAS EM CAPACIDADE DE USO}

Autora: DANIELE FOCHT

Orientador: Prof. Dr. GERD SPAROVEK

\section{RESUMO}

O Sistema de Classificação da Capacidade de Uso das Terras (SCCUT) vem sendo utilizado para objetivos diversos daqueles para os quais foi formulado. Portanto, é necessário avaliar como seus critérios vêm sendo interpretados. A variabilidade induzida pelos avaliadores do SCCUT foi determinada em um estudo de caso, considerando a participação de especialistas com experiências profissionais distintas. Estes avaliadores foram dois professores e uma pesquisadora da área de conservação de solos, e quatro engenheiros agrônomos especializados na valoração de terras. $\mathrm{O}$ objeto do estudo foi a área de captação da Microbacia Hidrográfica do Córrego do Ceveiro, localizada no município de Piracicaba, Estado de São Paulo. Esta possui uma área de 1990,4 ha, ocupada em cerca de 66\% pelo cultivo intensivo da cana-de-açúcar. Cada avaliador, após a solicitação do material necessário, executou a classificação da capacidade de uso das terras para a microbacia em questão. Para analisar a variação entre as classificações, foram analisados os seguintes aspectos: (a) necessidades de 
avaliador para executar a classificação, (b) a forma pela qual as classificações de capacidade de uso das terras foram apresentadas, e (c) a classificação propriamente dita no que diz respeito às concordâncias espaciais e globais. Para a análise das concordâncias espaciais utilizou-se de um procedimento estatístico da análise multivariada discreta, o parâmetro Kappa $(\mathrm{k})$, que define a qualidade na concordância entre imagens em um sistema de informações geográficas. Para a análise de concordância global foram calculados intervalos de confiança da média e coeficientes de variação. Observações gerais indicaram que houve variação entre os avaliadores na solicitação de material necessário para a classificação. Outra observação foi a ausência de necessidade dos colaboradores, com exceção de um, em obter dados climáticos da região, fator importante no processo de decisão da classificação (Lepsch et al., 1991). Os resultados das classificações de cinco dos sete avaliadores puderam participar das concordâncias espaciais, face dois desses, especialistas na valoração de terras, terem feito classificações cuja distribuição de classes foi apresentada através de porcentagem, não podendo serem convertidas em imagens. Os cinco mapas de classificação foram comparados dois a dois. Os parâmetros $\mathrm{k}$ das concordâncias espaciais revelaram uma relação ruim entre as interpretações dos avaliadores 1,2 e 3 , envolvidos com a conservação de solos $(k=0,43-0,48)$ e entre os avaliadores 4 e 5 , experientes na valoração de terras, a qualidade de concordância foi considerada razoável $(k=0,52)$. Em contrapartida a maior parte dos cruzamentos entre classificações, indicou concordâncias com qualidade péssima $(K=0,23-0,27)$. As concordâncias globais indicaram a presença de amplos intervalos de confiança e altos coeficientes de variação (39\%-260 \%) para as classes de capacidade de uso. Pela análise dos resultados das concordâncias espaciais e globais concluiu-se que ocorreu uma grande variação intrínseca ao uso do Sistema de Classificação da Capacidade de Uso das Terras, em função do avaliador. Como causas principais dessa variação observou-se que: (a) as definições dos critérios para a determinação das classes de capacidade de uso proporcionam várias interpretações, devido a falta de definições objetivas onde encontram-se os esquemas de consulta iniciais; (b) não são todos os usuários do sistema que possuem total domínio sobre a metodologia; (c) o sistema vem sendo utilizado para objetivos que não aqueles a que foi 
formulado, como por exemplo, a valoração de terras. Uma revisão da metodologia do Sistema de Capacidade de Uso das Terras, dando ênfase às pressuposições básicas para sua utilização e elaboração de manuais direcionados aos outros objetivos, que não a conservação de solos, tenderia a minimizar esta subjetividade. 


\title{
THE EVALUATORS INFLUENCE ON LAND CAPABILITY CLASSIFICATION RESULTS
}

\author{
Author: DANIELE FOCHT \\ Adviser: Prof. Dr. GERD SPAROVEK
}

\section{SUMMARY}

The Land Use Capability Classification System (LUCCS) is being used for purposes other than for which it was designed. Therefore it is necessary to evaluate how its criteria are being interpreted. The variability induced by evaluator of the LUCCS was determined in a case study considering experts with different professional background. The volunteers were two university professors; one soil conservation researcher and four agronomists specialized in land evaluation for treasure definition. The study area was the Ceveiro Creek Microwatershed located in Piracicaba (Southeast of Brazil). The surface area is 1990 ha, used in about $66 \%$ for intensive sugarcane cropping. Each evaluator, after requiring the needed material, individually worked on the LUCCS for this area. The similarity between the classifications was determined by (a) the specific needs from each evaluator to perform the classification; (b) the format that the classification was presented (c) the classification itself based on global and spatial similarity. Spatial similarity was evaluated based on a multivariate discreet 
procedure represented by the Kappa index. Global similarity was evaluated by the coefficient of variance and the mean confidence interval. The needs for evaluation were different for each evaluator. All but one evaluator failed to request climatic data, considered important for Land Capability Classification. Only five of the classification results were used to assess spatial similarity because two of the evaluators presented their results as a percentage, which could not be transformed into images. The five maps were compared under each other in pairs. The Kappa index $(\mathrm{k})$ of spatial similarity showed weak agreement between evaluators 1, 2 and 3 (soil conservation experts) with $0.43<\mathrm{k}<0.48$ and reasonable similarity between evaluator 4 and 5 (land evaluation experts) with $k=0.52$. Most of the combinations showed very poor similarity with 0.23 $<\mathrm{k}<0.27$. Global similarity showed large mean confidence intervals and coefficients of variance (CV) with $39 \%<\mathrm{CV}<260 \%$. The results indicated that the evaluators' influence on the result of the evaluation was significant. The main reasons were: (a) multiple interpretation of important criteria and system definitions, (b) the system users do not totally understand the methodology (c) the system is being used for purposes such as land treasure definition, for which it was not designed. A system revision emphasizing basic concepts and objective directed manuals for purposes other than soil conservation, probably can reduce its subjectivity. 


\section{INTRODUÇÃO}

$\mathrm{O}$ aumento da necessidade de produção de alimentos devido ao crescimento populacional, provocou uma grande expansão da agricultura de exploração. Esse tipo de agricultura, caracterizada pela simples utilização das propriedades naturais dos recursos disponíveis, foi a precursora do esgotamento desses recursos. Dentre esses os mais afetados foram o solo e a água. Após a percepção dessa situação, a preocupação com a conservação dos recursos tornou-se uma constante. Dentro desse enfoque, o planejamento de uso das terras é ferramenta de extrema importância para a utilização adequada das áreas agrícolas, minimizando os problemas já existentes e mantendo o potencial das terras ainda intactas.

Os planejadores utilizam-se de avaliações que interrelacionam as diversas especificidades da terra com o ambiente com o duplo objetivo de preservação ambiental, mediante a conservação dos recursos naturais, e de aproveitamento do potencial das terras para fins produtivos. Dentre os sistemas de avaliação está o Sistema de Classificação da Capacidade do Uso das Terras (Lepsch et al., 1991). Baseado no sistema de capacidade de uso das terras norte-americano, tornou-se ferramenta básica para a definição da melhor utilização das terras encontrados em uma área rural. A avaliação executada com a caracterização química e física dos solos e do ambiente onde estes se encontram proporciona o estabelecimento de diretrizes para o aproveitamento racional das terras, ou seja, alia a conservação dos recursos disponíveis ao seu aproveitamento econômico. 
Devido ao nível de detalhe requerido para a classificação das terras em classes de capacidade de uso e à forma pela qual os critérios do sistema foram definidos, este foi, com o tempo, sendo empregado para avaliações que não diziam mais respeito unicamente às atividades agrícolas. Valoração de terras pela Companhia Energética do Estado de São Paulo (CESP) (Lepsch et al., 1991) e pelo Instituto Nacional de Colonização e Reforma Agrária (INCRA), processos de partilha de bens imóveis (Demétrio, 1995) e instrumento legal em políticas de gestão ambiental, são alguns dos objetivos pelos quais o Sistema de Classificação da Capacidade de uso das Terras acabou sendo aplicado.

Esta abertura de utilização proporcionada pelo sistema, onde a interpretação de seus indicadores depende do conhecimento do avaliador, mostra o grau de subjetividade intrínseco à metodologia. Esta subjetividade já havia sido percebida como um ponto negativo no sistema norte-americano de capacidade de uso das terras (Nakama, 1984), persistindo na versão elaborada no Brasil.

Partindo-se do pressuposto que a subjetividade proporcionada pelo Sistema de Classificação da Capacidade de Uso das Terras, aliada a forma diversificada pela qual seus critérios possam ser interpretados, proporcione diferentes classificações, e que esta variação não pode ser alta, para atender de forma adequada aos objetivos propostos, o presente trabalho teve por objetivo analisar a variação destas classificações para uma mesma área, em função do avaliador. Para tanto foram verificados os seguintes aspectos:

a) a forma pela qual foi realizada a classificação de capacidade de uso das terras,

b) concordância espacial de classificações de capacidade de uso das terras, executadas por diferentes avaliadores $\mathrm{e}$

c) concordância global destas mesmas classificações. 


\section{REVISÃO DE LITERATURA}

\subsection{Microbacia hidrográfica como unidade de estudo}

Bacia e microbacia hidrográficas, são escalas de trabalho consideradas como sistemas fechados no que diz respeito a uma parte das variáveis ambientais e é de extrema importância a sua utilização, quando possível, em trabalhos de planejamento. Nesse enfoque, grande é o número de definições existentes sobre o termo microbacia e qual sua relação dentro dos estudos relativos ao ambiente.

Uma definição de grande generalização foi a elaborada por Valente (1976) que considerou microbacia como sendo uma unidade física, composta de uma área de terra drenada por um determinado curso de água e limitada, perifericamente, por um divisor de águas.

Para explicar a diferença entre bacia hidrográfica e microbacia hidrográfica, Rocha (1991) definiu que ambos os termos relacionam-se com aquelas áreas drenadas pelas águas de chuvas as quais, por ravinas, canais e tributários, dirigem-se para um curso principal, com vazão efluente convergindo para uma única saída e desaguando diretamente no mar ou em um grande lago. Este mesmo autor colocou como única diferença uma limitação de área, não devendo a microbacia hidrográfica ultrapassar 10.000 hectares. Em contrapartida Christofoletti (1996) comentou que a formação de um conceito de bacia hidrográfica e o entendimento de sua complexidade, ainda é um grande desafio. 
Considerando o aspecto hidrológico, Moldan \& Cerny (1994) definiram microbacia como sendo a menor unidade da paisagem capaz de integrar os componentes

relacionados com a qualidade e disponibilidade de água. Esses mesmos autores comentaram ainda que processos como ciclos bioquímicos de nutrientes, acumulação ou diminuição de substâncias tóxicas, intemperismo, erosão e transportes de material, podem ser mais bem estudados e entendidos se bacias hidrográficas forem utilizadas como escala de trabalho. Relacionando estudos de ordem ambiental, Jenkins et al. (1994) explicaram que bacia hidrográfica é a unidade ecossistêmica e morfológica que melhor reflete os impactos das interferências antrópicas, tais como a ocupação de terras por atividades agrícolas.

Para demonstrar as vantagens do uso de bacias hidrográficas como unidade de estudo, Christofoletti (1996) enfocou que as bacias hidrográficas são unidades funcionais com expressividade espacial, sendo sistema ambientais complexos em sua estrutura, funcionamento e evolução.

\subsection{Sistemas para a determinação da potencialidade das terras}

Assim como ocorre em outras áreas do conhecimento, o progresso nos estudos relativos a solos tende a aumentar com o decorrer do tempo. Como conseqüência, grande é o volume de informações geradas. No entanto, o emprego desses dados tem se mostrado muito deficiente no que diz respeito à parte interpretativa (Beek, 1978; Prado, 1996). Isso decorre da forma técnica como estes dados são apresentados, tornando necessárias interpretações específicas para a definição de parâmetros que os tornem viáveis para outros fins como o planejamento agrícola.

As interpretações de levantamentos pedológicos são predições do comportamento dos solos sob sistemas de manejo específicos e sob determinadas condições ambientais (Steele, 1967). Estas interpretações, chamadas de técnicas ou interpretativas, consistem na reunião, reorganização e apresentação de informações 
disponiveis sobre solos, previamente classificados e mapeados, para aplicações práticas (França, 1980b). França (1980a) separou estas classificações em dois grupos distintos:

a) simples: possuem apenas um nivel categórico e poucas classes, como por exemplo, classificação por necessidade de calcário;

b) complexos: com dois ou mais níveis categóricos e muitas classes, como por exemplo a classificação norte-americana de capacidade de uso das terras.

Nesse contexto, Lepsch et al. (1991) acrescentaram que a interpretação dos dados de solos podem ter uma solução distinta, de acordo com o objetivo estabelecido para a interpretação. Assim, para que um sistema técnico possa ser facilmente entendido e utiliżado, deve basear-se na avaliação de critérios que realmente têm significância para o objetivo visado (França, 1980a).

Com a grande expansão das áreas agrícolas e os problemas decorrentes de sua utilização inadequada, ocorreu a necessidade de interpretações que diagnosticassem problemas e indicassem o potencial das terras para a determinação do seu melhor uso. Atendendo a essas perspectivas, surgiram no Brasil o Sistema de Classificação da Capacidade do Uso das Terras (Lepsch et al., 1983) e o Sistema de Avaliação da Aptidão Agrícola das Terras (Ramalho Filho et al., 1978). O primeiro pressupõe a utilização de um manejo moderadamente alto (Lepsch et al., 1991) ou seja, que envolva práticas ou técnicas de melhoramento e de proteção do solo que estão ao alcance da maioria dos agricultores, e caracteriza áreas dando enfoque ao planejamento das práticas de conservação do solo. É apropriado para o uso em porções limitadas de terra, como propriedades agrícolas, microbacias e áreas de captação, havendo a necessidade de um grande número de informações sobre solos. O segundo avalia a aptidão de terras segundo três niveis de manejo, dando uma orientação de como devem ser utilizados os recursos da terra dentro de um planejamento regional e nacional, com ênfase à indicação das melhores terras para o cultivo de plantas de ciclo curto (Ramalho Filho \& Beek, 1995), necessitando de um menor número pontual de informações pedológicas que 
podem ser fornecidas a partir de um levantamento exploratório, face à grande escala de trabalho utilizada.

\subsection{Sistema de Classificação da Capacidade de Uso das Terras (SCCUT)}

As principais exigências para o estabelecimento do melhor uso da terra decorrem de um conjunto de interpretações do próprio solo e do meio onde este se encontra. Por esse motivo o SCCUT estabelece sua classificação baseado no termo terra que, diferente do termo solo, é mais amplo sendo considerado como um segmento da superfície do globo terrestre reconhecido em função de características do ambiente onde se encontra e das atividades antrópicas, até o ponto que estas influenciem seu uso pelo homem (FAO, 1976). Nesse contexto, solo possui uma caracterização mais restrita, sendo utilizado como um dos componentes de avaliação da terra.

Foram essas as prerrogativas que nortearam a elaboração do SCCUT no qual a capacidade de uso da terra é entendida como sua adaptabilidade para diversos fins, sem que sofra depauperamento pelos fatores de desgaste e empobrecimento (Lepsch et al., 1991).

Esse tipo de sistema foi definido por Marques (1971) como sendo a identificação, discriminação, quantificação, interpretação e mapeamento de um conjunto mínimo de condições e características da terra, condicionadores de sua capacidade de uso. Elaborado primordialmente para trabalhos de conservação do solo, leva em consideração fatores que não dizem respeito apenas a este objetivo. Assim, face ao grande número de informações geradas na classificação, o SCCUT permite uma ampla utilização.

\subsubsection{Histórico}

O desenvolvimento de qualquer sistema é precedido de uma série de pesquisas embasadoras de sua estrutura. O SCCUT teve sua linha de pesquisa iniciada entre 1930 e 1940. Nesta época o Soil Conservation Service - EUA, desenvolveu a "Land 
Capability Classification" como ferramenta para a avaliação da necessidade da utilização de estruturas conservacionistas em grandes áreas agrícolas. A partir de então surgiu a necessidade de adaptação do sistema para sua utilização em áreas menores de terra (Helms, 1997).

Nesse meio tempo, pesquisadores brasileiros já discutiam a necessidade de estudos específicos sobre solos que levassem em consideração aspectos conservacionistas. Em 1957, foi realizada no Rio de Janeiro, sob a organização do Escritório Técnico de Agricultura, uma reunião geral das entidades e dos técnicos brasileiros responsáveis pela solução dos problemas de levantamento e estudo de solos em geral, dando partida às discussões da publicação de um manual próprio. Segundo Marques (1971), nesse mesmo ano é publicada a I Aproximação do Manual Brasileiro. Após uma série de críticas sugeridas e enviadas ao grupo que desenvolveu a primeira versão, foi necessária a publicação de uma outra, com as informações coletadas posteriormente. Dessa forma, em 1958 foi editada pelo Escritório Técnico Brasil Estados Unidos, a segunda versão intitulada Manual Brasileiro para Levantamentos Conservacionistas.

No Brasil o Manual tornou-se de maior necessidade e difusão graças ao surgimento de orgãos governamentais ligados à implantação da reforma agrária (Marques, 1971). Ao mesmo tempo, nos Estados Unidos estava sendo publicada a "Land - Capability Classification" (Klingebiel \& Montgomery, 1961). Essa publicação foi de grande importância, atendendo às necessidades sugeridas pelos pesquisadores norte-americanos no que dizia respeito a uma interpretação mais criteriosa dos dados pedológicos para a indicação dos melhores usos para as terras. A "Land - Capability Classification" foi a precursora da maioria dos sistemas de classificação de terras desenvolvidos posteriormente.

Anos mais tarde, após a boa aceitação do Manual Brasileiro para Levantamentos Conservacionistas e com os avanços científicos advindos da "Land - Capability Classification", houve um convênio entre o Escritório Técnico Brasil - Estados Unidos e 
a Sociedade Brasileira de Conservação de Solos, com o intuito de uma revisão sobre esse Manual (Marques, 1971). Dessa forma, em 1971 ocorreu a publicação da III aproximação, agora intitulada Manual Brasileiro para Levantamento da Capacidade de Uso das Terras (Marques, 1971). Esse Manual então, contemplava critérios para avaliação de inúmeros fatores relativos aos solos, tratando de sua conservação de uma forma mais coerente e com uma amplitude de utilização que a época exigia.

Com a repercussão da preocupação com o ambiente no final da década de setenta, início da década de oitenta e com a evolução da ciência do solo que proporcionava um número cada vez maior de dados, houve a necessidade da reedição do manual instituído em 1971. Em 1983, após extensa reorganização foi publicada a IV aproximação agora denominada Manual para Levantamento Utilitário do Meio Físico e Classificação de Terras no Sistema de Capacidade de Uso (Lepsch et al., 1983), recomendado para fins de planejamento de práticas de conservação de solo, ao nível de propriedades ou empresas agrícolas, ou para pequenas bacias hidrográficas. Nesse foram descartadas as considerações relevantes ao levantamento das condições sócioeconômicas, devido principalmente a complexidade das variáveis que interferem nesse tipo de análise, em nível regional.

\subsubsection{Metodologia}

O SCCUT é uma classificação técnica-interpretativa, ou seja, os indivíduos são agrupados em função de determinadas características de interesse prático e específico, que representam um grupamento de tipos de solos sem considerar a localização ou as características econômicas da terra (Lepsch et al., 1991).

O levantamento pedológico da área de estudo é item imprescindivel de análise para classificação de terras em capacidade de uso, mas sua avaliação deve estar limitada ao fim a que se destina o estudo. Como são inúmeras as aplicações de um levantamento de solos, uma classificação técnica deve organizar seus dados de uma forma específica, de acordo com o objetivo proposto (França, 1980a). 
Como o SCCUT é utilizado para classificação em porções limitadas de terra, há a necessidade de um grande número de informações que somente podem ser obtidas em um levantamento de solos detalhado ou, no mínimo, semidetalhado. Normalmente esses dados não existem ao nível de propriedade agrícola, obrigando os avaliadores a coletarem essas informações no campo. Para isso França (1980a) recomendou a observação dos seguintes itens:

- profundidade efetiva do solo, relacionada à expansão do sistema radicular;

- presença de fertilidade alta ou cujas características físicas e químicas do solo proporcionem correção;

- capacidade de armazenamento de água em forma disponível às plantas;

- drenagem interna, assegurando boa aeração;

- baixa erodibilidade;

- relevo favorável a mecanização e

- ambiente com condições térmicas e hídricas adequadas.

O levantamento de características físicas no campo, como presença de erosão, pedregosidade e condiçães de relevo são importantes para a interpretação dos dados pedológicos e posterior determinação da classificação da capacidade do uso das terras. Para a determinação da classificação ainda são necessários dados relativos ao clima predominante na área, com um histórico dos principais distúrbios climáticos de maior importância ocorridos nos últimos anos, como geadas e ventos frios. Há a necessidade de dados meteorológicos, sendo desejável um período de no mínimo dez anos de observação, incluindo dados de precipitação e temperatura (Lepsch et al., 1991). Da interrelação dessas inúmeras informações as unidades de solos são enquadradas dentro das categorias que fazem parte do SCCUT. A hierarquização do SCCUT pode ser visualizada esquematicamente na figura 1. 


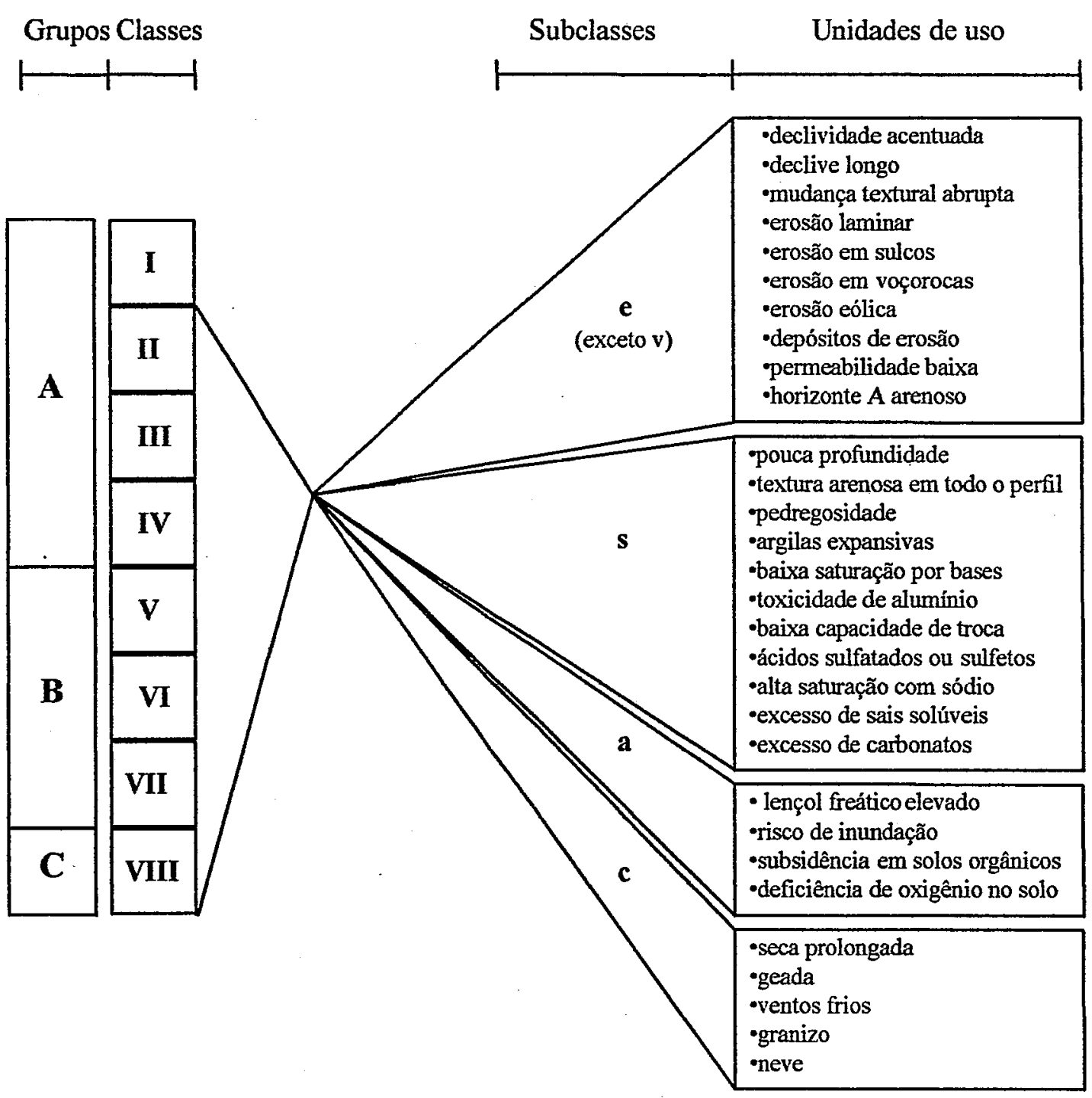

Figura 1. Esquema das categorias do SCCUT (Lepsch et al., 1991).

\subsubsection{Categorias do sistema}

Segundo Lepsch et al. (1991), o SCCUT está organizado da seguinte forma:

$\Rightarrow$ Grupos de capacidade de uso (A, B e C): estabelecidos com base nos tipos de intensidade de uso das terras;

$\Rightarrow$ Classes de capacidade de uso (I a VIII): baseadas no grau de limitação de uso; 
$\Rightarrow$ Subclasses de capacidade de uso (IIe, IIIe, IIIa, etc.): baseadas na natureza da limitação de uso;

$\Rightarrow$ Unidades de capacidade de uso (Ile-1, Iie-2, IIIe-1, etc.): baseadas em condições específicas que afetam o uso ou manejo da terra.

\subsubsection{Grupos de capacidade de uso}

Constituem-se em categorias de nível mais elevado e generalizado, estabelecidos com base na maior ou menor intensidade de uso das terras, designada em ordem decrescente pelas letras $\mathrm{A}, \mathrm{B} \mathrm{e} \mathrm{C}$.

Grupo A: refere-se às terras passíveis de utilização com culturas anuais, perenes, pastagens e/ou reflorestamentos e vida silvestre. Fazem parte desse grupo as classes I, II, III e IV.

Grupo B: designa as terras impróprias para cultivos intensivos, mas ainda adaptadas para pastagens e/ou reflorestamentos. Fazem parte desse grupo as classes V, VI e VII.

Grupo C: indica as terras não adequadas para cultivos anuais, perenes, pastagens ou reflorestamento, porém apropriadas para proteção da flora e fauna silvestre, recreação ou armazenamento de água. Faz parte desse grupo a classe VIII.

\subsubsection{Classes de capacidade de uso}

São agrupamentos de terra que apresentam o mesmo grau de limitação. Essas classes são em número de oito sendo designadas por algarismos romanos. A caracterização das classes de capacidade de uso leva em conta a maior ou menor complexidade das práticas conservacionistas, principalmente aquelas de controle da erosão. As práticas de conservação do solo podem ser subdivididas em práticas de controle à erosão destinadas a diminuir o processo erosivo, como terraceamento $\mathrm{e}$ plantio com cultivo em nível, e práticas complementares de melhoramento, que 
procuram melhorar ou recuperar as condições de produtividade das terras como a adubação verde e a rotação de culturas.

Classe I: terras cultiváveis, aparentemente sem problemas especiais de conservação. A cor de reconhecimento em mapeamento é o verde claro.

Classe II: terras cultiváveis que possuem problemas simples de conservação e/ou de manutenção de melhoramentos. Caracterizada em mapeamento pela cor amarela.

Classe III: terras cultiváveis com problemas complexos de conservação e/ou de manutenção de melhoramentos. Recebe a cor vermelha como identificadora em mapeamento.

Classe IV: terras cultiváveis apenas ocasionalmente ou em extensão limitada, com sérios problemas de conservação. A sua cor de convenção em mapeamento é o azul.

Classe V: terras em geral aptas para pastagens e, em alguns casos, para reflorestamento, sem a necessidade de práticas especiais de conservação. É convencionada em mapeamento pela cor verde escuro.

Classe VI terras em geral aptas para pastagens e/ou reflorestamentos, com problemas simples de conservação. São cultiváveis apenas em casos especiais de algumas culturas permanentes protetoras de solo. A cor de identificação em mapeamento é o alaranjado.

Classe VII: terras em geral aptas para pastagens ou reflorestamento, com problemas complexos de conservação. Em mapeamento é reconhecida pela cor marrom.

Classe VIII: terras impróprias para cultura, pastagem ou reflorestamento, podendo servir como abrigo e proteção da fauna e flora silvestre, como ambiente para recreação, ou para fins de armazenamento de água. Sua cor de reconhecimento em mapeamento é o roxo. 


\subsubsection{Subclasses de capacidade de uso}

Representam as classes de capacidade de uso qualificadas em função da natureza da limitação, tornando mais evidentes as práticas ou grupos de práticas conservacionistas necessárias. A natureza da limitação é designada por letras minúsculas, de modo que a subclasse de capacidade de uso é representada pelo algarismo romano indicador da classe, seguido da letra designativa do fator limitante. As limitações de uso podem ser pela erosão presente ou risco de erosão (e), limitações relativas ao solo (s), limitações por excesso de água (a) e limitações climáticas (c). Como a Classe I só permite limitações ligeiras, esta não admite subclasses.

\subsubsection{Unidades de capacidade de uso}

As unidades de capacidade de uso tornam mais evidente ainda a natureza das limitações, facilitando o processo de estabelecimento das práticas de manejo. Designam-se estes fatores limitantes pela colocação de algarismos arábicos à direita do símbolo da subclasse, separados por um hífen. Dessa forma, a unidade de capacidade de uso representa a subclasse perfeitamente qualificada em função do fator limitante. Essa categoria pode ser explicada pelos seguintes exemplos: IIIs-1 (possui limitação cuja natureza é o solo, por problemas de fertilidade), IIIs-2 (possui limitação cuja natureza é o solo, por problemas de pedregosidade), IIIs-3 (possui limitação cuja natureza é o solo, por problemas de excesso de sais solúveis).

\subsubsection{Aplicações do sistema}

A avaliação de inúmeros fatores do solo e do ambiente onde este se encontra, necessários para a classificação das terras de acordo com sua capacidade de uso, abriu uma grande amplitude de utilização do sistema. Lepsch et al. (1991) comentaram que o sistema de classificação de terras em classes de capacidade de uso foi elaborado prinordialmente para atender os planejamentos de práticas conservacionistas, mas 
mesmo assim leva em consideração outros fatores além daqueles de exclusivo interesse às práticas de controle da erosão.

O sistema hoje é aplicado normalmente com o objetivo do planejamento de uso da terra, zoneamentos agrícolas, na valoração de terras e na legalização de áreas de preservação ambiental. $\mathrm{Na}$ época de sua concepção o sistema também era utilizado para fins de irrigação, mas como há a tendência das interpretações serem realizadas em função do fim a que se destinam, foi desenvolvida a Classificação de Terras para Fins de Irrigação (Carter, 1993) que leva em consideração critérios adotados de um manual norte-americano de irrigação. O mesmo ocorreu com a classificação de terras para fins de manejo da fertilidade dos solos a qual inicialmente seguia os critérios da "Land Capability Classification" e posteriormente passou a ser baseada em um manual próprio, - "Classificación de suelos en base a su fertlidad" (Buol et al., 1974). Esse manual agrupa os solos de acordo com as características da análise de suas propriedades quimicas e físicas (Sanchez et al., 1982).

Devido ao grau de detalhes fornecidos em sua classificação, o SCCUT pode ser utilizado como elemento enriquecedor de detalhes em trabalhos de avaliação de grandes áreas em conjunto ao Sistema de Avaliação da Aptidão Agrícola das Terras, como ocorreu no macrozoneamento das terras da região do Rio Ribeira de Iguape (Lepsch et al., 1990). Silva (1993) com o intuíto de analisar diferentes métodos de avaliação de terras para o desenvolvimento agrícola em um município paranaense, também valeu-se da utilização dos critérios do SCCUT, em conjunto a outras metodologias que indicam a potencialidade de terras. Casalinho \& Bourscheid (1996) utilizaram o SCCUT para fins de assentamento rural, procurando subdividir determinada área de acordo com sua capacidade de uso, na tentativa de promover um desenvolvimento agrícola mais homogêneo entre as propriedades.

A valoração de terras é outro objetivo visado pelos usuários do SCCUT. O Instituto Nacional de Colonização e Reforma Agrária (INCRA) se utiliza do sistema para valorar as terras em processos de desapropriação por interesse social, mediante sua 
instrução normativa $n^{\circ} 8$ (Brasil, 1993), onde a avaliação é utilizada no estudo de viabilidade de assentamentos rurais, bem como no dimensionamento de seus lotes. A Companhia Energética do Estado de São Paulo (CESP) utiliza o sistema para complementar o levantamento topográfico-cadastral de áreas ocupadas pelas bacias de inundação de usinas hidrelétricas, para fim de desapropriação (Lepsch et al., 1991).

Demétrio (1995) defendeu a utilização do SCCUT como ferramenta básica nos trabalhos de perícia de avaliação de imóveis rurais. Seu argumento é que o valor da terra está diretamente relacionado com o aproveitamento permitido e a liberdade de uso, de acordo com sua capacidade que ela propricia ao proprietário/explorador, significando que, quanto maior o grau de aproveitamento da área, sua intensidade e variabilidade de utilização do solo, maior será o seu valor.

Em relação à legalização de áreas de preservação ambiental, verifica-se que segundo a Resolução ñ 10 do Conselho Nacional do Meio Ambiente (CONAMA) de 14 de dezembro de 1988, há a necessidade de um zoneamento agropecuário da área a ser legalizada, que preconiza o estabelecimento das unidades que podem ou não ser cultivadas, identificando aquelas sensiveis à erosão e as recomendações de seu melhor uso e manejo (Brasil, 1992). Por caracterizar esses critérios em sua classificação, o SCCUT tem sido utilizado como base para o estabelecimento dessas unidades.

\subsubsection{Problemas do sistema}

O SCCUT apresenta alguns problemas para a sua utilização. Um deles refere-se ao grande número de informações necessárias para sua utilização, os quais demandam de tempo e custo elevados para obtenção gerando, muitas vezes, diagnósticos com excesso de detalhes, ultrapassando as necessidades do objetivo a que se destina a avaliação.

Outro item a ser questionado refere-se à unificação da forma de avaliação de seus critérios, não levando em consideração as diferenças regionais. Hudson (1971) sugeriu que não deve existir apenas um sistema de classificação da capacidade de uso das terras mas diversos, atendendo assim às singularidades de cada região fisiográfica no 
que se refere ao clima e questões sociais ligadas ao uso das terras. Em relação aos critérios usados na classificação, a ausência dos elementos erosividade da chuva e comprimento de rampa torna o sistema pouco sensível às variações do potencial de erosão entre regiões e entre tipos de paisagem ${ }^{\text {}}$.

Mesmo sendo preferencialmente ferramenta de auxílio na tomada de decisão dos planejadores agrícolas, para determinação de práticas conservacionistas, a forma e o número de informações proporcionadas pelo SCCUT, como já foi visto, tem muitas aplicações. Essa amplitude de utilização pressupõe que a avaliação dos critérios do sistema não tem apenas uma definição. Ocorre a tendência dos usuários do SCCUT interpretarem os critérios de sua metodologia de acordo com seu conhecimento e objetivo a ser atingido.

\subsection{Sistemas de Informações Geográficas (S/Gs)}

Alves (1990) definiu Sistemas de Informações Geográficas como sendo sistemas destinados à aquisição e tratamento de dados georreferenciados (referência espacial), permitindo a manipulação de dados de diversas fontes, recuperando e combinando informações e efetuando vários tipos de análises.

A importância dos Sistemas de Informações Geográficas foi ressaltada por Assunção et al. (1990) que enfatizaram a necessidade dos sistemas para se obter e manipular dados georreferenciados e pela sua capacidade na integração de dados obtidos de diferentes fontes como imagens orbitais, mapas planialtimétricos, mapas geológicos e outros. No estudo do planejamento envolvendo solo e água, Mellerowicz et al. (1994) comentaram que houve aumento da aplicação destes sistemas devido à melhora da qualidade dos sistemas disponíveis, disponibilidade e facilidade de manipulação dos sistemas e aumento da disponibilidade de informações básicas necessárias à sua utilização como mapas e imagens. Neste aspecto, Ranieri (1996) ainda comentou que o

\footnotetext{
' ROLOFF, G. (Universidade Federal do Paraná). Comunicação pessoal, 1998.
} 
aumento da demanda por trabalhos de planejamento que exijam menor gasto de tempo, foi outro aspecto de importância para o estabelecimento do uso destes sistemas.

Como no caso dos profissionais que perceberam a agilidade na estratificação de informações com a utilização de um SIG, trabalhando na definição de zoneamentos de áreas de preservação ambiental (Griffith et al., 1997), a utilização desta mesma ferramenta em planejamento agrícola, mostra-se como uma opção importante nos processos que antecedem às tomadas de decisão, principalmente na compilação de dados.

Burrough (1986) definiu como três os componentes básicos de um SIG: equipamento computacional, conjunto de módulos aplicativos ou programa e um contexto organizacional apropriado, sendo que estes componentes devem estar balanceados.

Para as etapas de trabalho, Assad (1995) citou os procedimentos mais adequados que devem ser seguidos:

1. Definição de uma escala de trabalho e unidade de medidas.

2. Entrada de dados.

3. Transformação dos dados quando necessário.

4. Obtenção de novos planos de informação, mediante reclassificação, cruzamento e cálculos sobre os dados de entrada e

5. Saída dos dados. 


\section{MATERIAL E MÉTODOS}

\subsection{Material}

\subsection{1 Área de estudo}

\subsubsection{Localização}

A área de estudo é a área de contribuição da principal represa existente na Microbacia Hidrográfica do Córrego do Ceveiro (MHCC). Esse córrego é afluente do Rio Piracicaba que forma com os Rios Camanducaia, Jaguari, Atibaia e Corumbataí a mais importante bacia do Estado de São Paulo, a Bacia do Rio Piracicaba.

A MHCC está localizada no município de Piracicaba, Estado de São Paulo, situada entre as coordenadas $22^{\circ} 37^{\prime} \mathrm{S}$ e $22^{\circ} 40^{\prime} \mathrm{S}$ e $47^{\circ} 43^{\prime} \mathrm{O}$ e $47^{\circ} 47^{\prime} \mathrm{O}$ (Figura 2). Dos 2200 ha da MHCC, 1990,4 ha são da área de contribuição da represa. A diferença entre as áreas da microbacia e de contribuição da represa, refere-se a concentração de uma área urbanizada existente à jusante da microbacia que foi descartada para as avaliações do presente trabalho.

A região onde encontra-se a MHCC é tradicionalmente agrícola, de intenso cultivo canavieiro, cujo manejo está atualmente em modificação, face à nova legislação ambiental que requer a eliminação da queima da cana-de-açúcar. Portanto o estudo das potencialidades de uso de suas terras torna-se de relevante importância. 


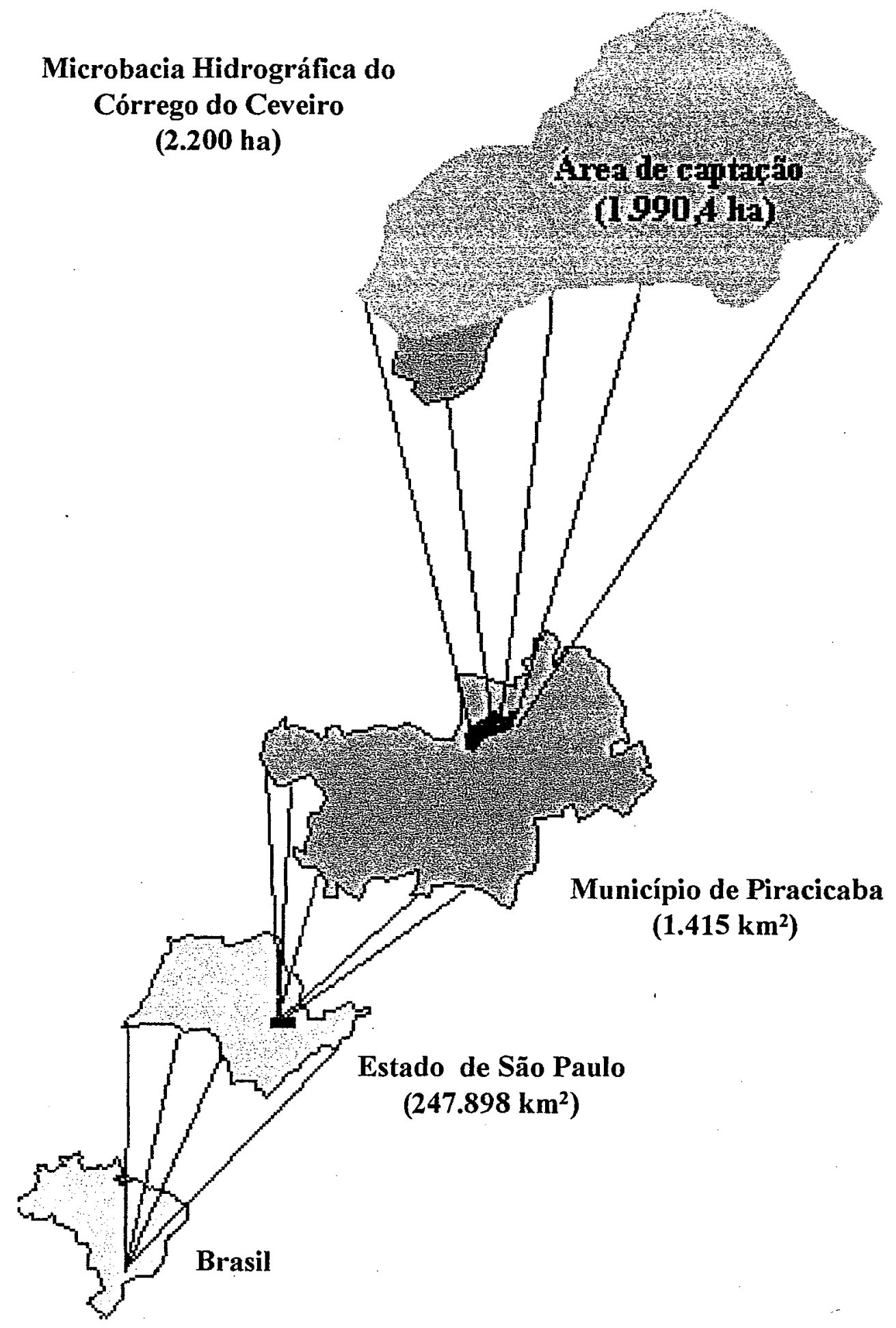

Figura 2. Localização da área de captação na Microbacia Hidrográfica do Córrego do Ceveiro. 


\subsubsection{Clima}

O município de Piracicaba possui uma distribuição pluviométrica caracterizada por um período de chuvas bem definido que se estende de outubro a março e outro período seco, de abril a setembro, com uma passagem bem abrupta entre esses períodos (Tabela 1).

Tabela 1. Dados climatológicos do município de Piracicaba (média de dez anos).

\begin{tabular}{lcccc}
\hline \multicolumn{1}{c}{ Mếs } & $\begin{array}{c}\text { Temperatura } \\
\text { Média }\end{array}$ & $\begin{array}{c}\text { Precipitação } \\
(\mathbf{m m})\end{array}$ & $\begin{array}{c}\text { Evapotranspiração } \\
(\mathbf{m m})\end{array}$ & $\begin{array}{c}\text { Precip. - Evap. } \\
(\mathbf{m m})\end{array}$ \\
\hline Janeiro & 24,0 & 217 & 124 & 93 \\
Fevereiro & 24,7 & 183 & 107 & 76 \\
Março & 23,9 & 136 & 114 & 22 \\
Abril & 21,0 & 65 & 79 & -14 \\
Maio & 17,6 & 52 & 68 & -16 \\
Junho & 16,8 & 46 & 60 & -14 \\
Julho & 17,2 & 26 & 67 & -41 \\
Agosto & 18,9 & 29 & 87 & -58 \\
Setembro & 20,3 & 60 & 96 & -30 \\
Outubro & 22,2 & 108 & 125 & -17 \\
Novembro & 22,9 & 132 & 132 & 0 \\
Dezembro & 23,8 & 200 & 131 & 69 \\
\hline
\end{tabular}

Fonte: Departamento de Física e Meteorologia, ESALQ-USP. 
Segundo Köppen, a área apresenta clima Cwa, definido como mesófilo úmido sub tropical com inverno seco e temperatura do mês mais quente superior a $22^{\circ} \mathrm{C}$.

O balanço hídrico da região revela a ocorrência de deficiência de água no solo entre os meses de junho e outubro, e um excesso de água nos meses de novembro a maio.

\subsubsection{Relevo}

$\mathrm{O}$ relevo da MHCC é caracterizado como ondulado a forte ondulado, onde a topografia possui uma variação de altitude entre $460 \mathrm{~m}$ e $580 \mathrm{~m}$. Há uma predominância do relevo entre $10 \%$ e $15 \%$ de declividade (Figura 5 a).

\subsubsection{Vegetação}

Originalmente a vegetação natural da área era do tipo mesófila semidecídua, com ocorrência de ripárias nas margens dos cursos d'água.

Atualmente verifica-se a extinção desta vegetação, devido ao grande avanço da monocultura de cana-de-açúcar. Fiorio (1998) enfatizou esta situação comentando que a vegetação natural está restrita a algumas partes da rede de drenagem da MHCC e nas partes mais movimentadas do relevo.

\subsubsection{Geologia}

Na MHCC predominam rochas da Formação Corumbataí do Grupo Passa Dois, com arenitos da Formação Pirambóia e da Formação Serra Geral e intrusivas básicas associadas, ambas pertencentes ao Grupo São Bento (IPT, 1981).

Nos topos do relevo encontram-se os solos oriundos da Formação Pirambóia caracterizados por sucessivas camadas de arenitos. A Formação Serra Geral ocorre na cabeceira da microbacia, recobrindo a Formação Pirambóia. A Formação Corumbataí, constituída principalmente por folhelhos cinzentos, argilitos e siltitos, ocorre no restante na microbacia. 


\subsubsection{Solos}

Os solos da MHCC são caracterizados por sete grandes grupos: Podzólicos Vermelho-Amarelo (PV), Podzólico Vermelho-Escuro (PE), Terra Roxa Estruturada (TE), Cambissolo (C), Aluviais (A), Litólicos (Li) e Hidromórficos (H) (Fiorio, 1998). De acordo com suas especificidades de caráter físico ou químico, estes grandes grupos de solos foram responsáveis pela definição de trinta e uma unidades dispostas na MHCC, conforme apresentado na figura 3.

A descrição das unidades é a seguinte:

PV1 = Podzólico Vermelho-Amarelo, endoálico, Tb, A moderado ou chernozêmico, texturạ arenosa/média.

PV2 = Podzólico Vermelho-Amarelo, álico, Ta, A moderado, textura arenosa/média.

PV3 = Podzólico Vermelho-Amarelo, álico $\mathrm{Ta}$ ou $\mathrm{Tb}, \mathrm{A}$ moderado arênico, textura arenosa/média.

PV4 = Podzólico Vermelho-Amarelo, eutrófico, $\mathrm{Tb}, \mathrm{A}$ moderado, textura arenosa/média.

PV5 = Podzólico Vermelho-Amarelo, eutrófico, $\mathrm{Tb}, \mathrm{A}$ moderado, textura média/argilosa.

PV6 = Podzólico Vermelho-Amarelo, eutrófico, $\mathrm{Ta}, \mathrm{A}$ moderado, textura média/argilosa.

PV7 = Podzólico Vermelho-Amarelo, endoálico, $\mathrm{Tb}, \mathrm{A}$ moderado, textura média/argilosa.

PV8 = Podzólico Vermelho-Amarelo, eutrófico, $\mathrm{Ta}$ ou Tb, A moderado (arênico), textura arenosa/argilosa.

PV1pp = Podzólico Vermelho-Amarelo, endoálico, Tb, A moderado ou chernozêmico, textura arenosa/média, fase pouco profunda. 
PV2pp = Podzólico Vermelho-Amarelo, álico, Ta, A moderado, textura arenosa/média fase pouco profunda.

PV4pp = Podzólico Vermelho-Amarelo, eutrófico, $\mathrm{Tb}, \mathrm{A}$ moderado, textura arenosa/média fase pouco profunda.

PV5pp = Podzólico Vermelho-Amarelo, eutrófico, $\mathrm{Tb}, \mathrm{A}$ moderado, textura média/argilosa fase pouco profunda.

PV6pp = Podzólico Vermelho-Amarelo, eutrófico, Ta, A moderado, textura média/argilosa fase pouco profunda.

PV7pp = Podzólico Vermelho-Amarelo, endoálico, Tb, A moderado, textura média/argilosa fase pouco profunda.

$P E=$ Grupamento indiscriminado de Podzólico Vermelho-Escuro, textura argilosa ou argilosa/muito argilosa com ou sem cascalho (Unidade Campestre).

$\mathrm{TE}=$ Terra Roxa Estruturada, eutrófica, Tb, A moderado, textura argilosa (Unidade Estruturada).

TEP = Terra Roxa Estruturada Podzólica, eutrófica, Tb, A moderado, textura média/argilosa (Unidade Santana).

$\mathrm{Cbl}=$ Cambissolo, eutrófico ou distrófico, $\mathrm{Ta}$ ou $\mathrm{Tb}, \mathrm{A}$ moderado, textura argilosa.

$\mathrm{Cb} 2$ = Cambissolo, álico, Ta, A moderado, textura média .

$\mathrm{Cb3}=$ Cambissolo, eutrófico, Ta, A moderado, textura média .

$\mathrm{A}=$ Grupamento indiscriminado de solos aluviais.

Li 1 = Solo Litólico, eutrófico, Ta ou Tb, A moderado ou chernozêmico, textura média,.substrato siltitos da Formação. Corumbataí.

Li $1 \mathrm{cc}=$ Solo Litólico, eutrófico, $\mathrm{Ta}$ ou $\mathrm{Tb}, \mathrm{A}$ moderado ou chernozêmico, textura média, com cascalhos, substrato siltitos da Formação. Corumbataí.

Li 2 = Solo Litólico, álico, Ta, A moderado, textura média, substrato siltitos da Formação Corumbataí. 
Li 3 = Solo Litólico, eutrófico, $\mathrm{Ta}$ ou $\mathrm{Tb}, \mathrm{A}$ moderado ou chernozêmico, textura argilosa, substrato folhelho da Formação. Corumbataí.

Li 4 = Solo Litólico, álico, Ta, A moderado, textura argilosa, substrato folhelho da Formação Corumbataí.

Li 5 = Solo Litólico, distrófico, Tb, A moderado, textura média, substrato arenitos da Formação Pirambóia.

Li 6 = Complexo Li3 + PV5+Cb2.

- Li 7 = Solos litólicos substrato diabásio + cambissolos + TEpp todos eutróficos, Tb, A moderado, textura argilosa.

Hi 1 = Solo Hidromórfico, álico, Ta, A moderado, textura arenosa/média.

Hi 2 = Solo Hidromórfico, eutrófico, Tb, A moderado, textura média/argilosa. 


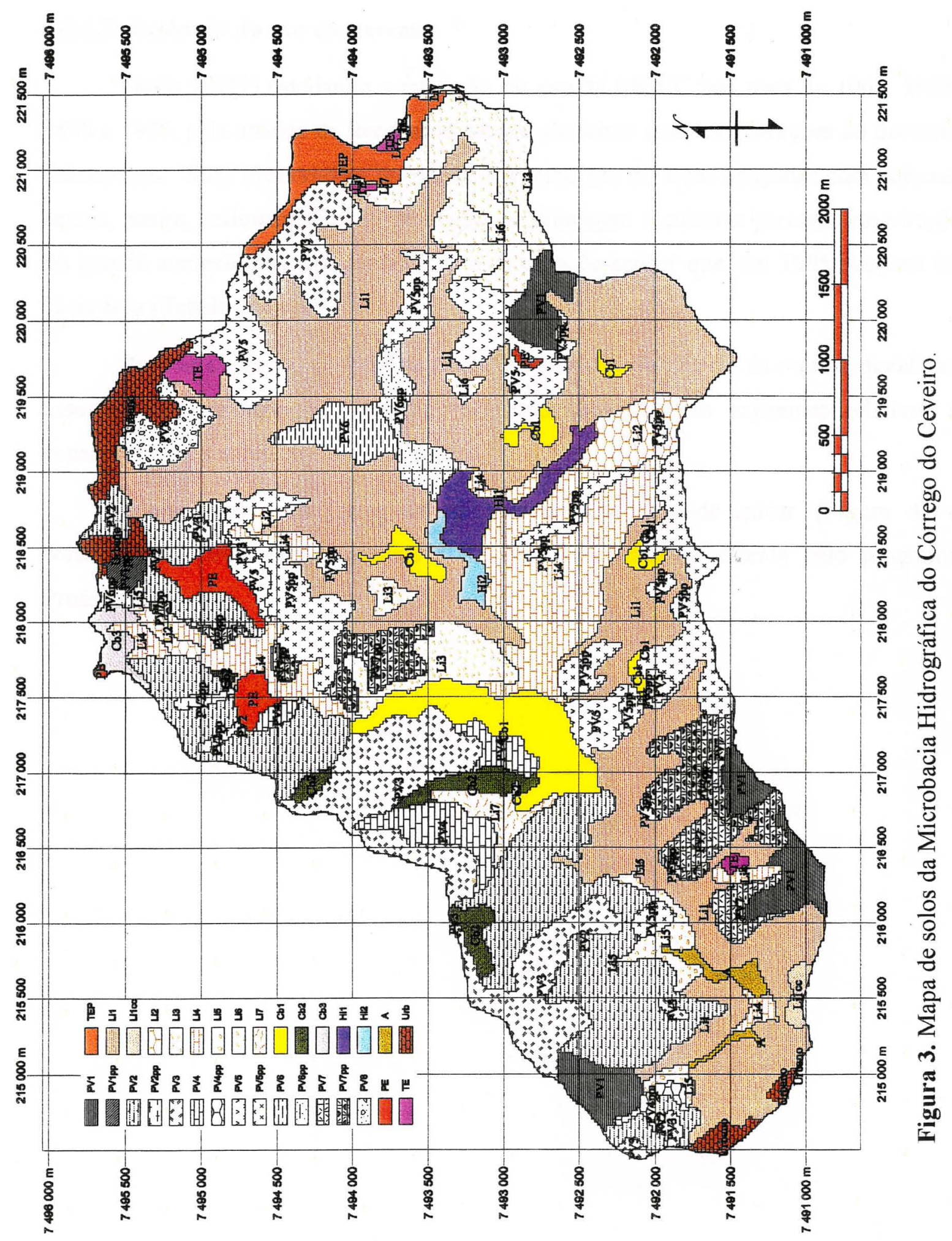




\subsubsection{Evolução do uso das terras}

Fiorio (1998) estudando a evolução do uso da MHCC nos anos de 1962, 1965, 1978 e 1995, pela análise de fotografias aéreas, percebeu grandes alterações no decorrer desses anos. Suas observações revelaram a diminuição de áreas ocupadas com culturas anuais, pastos, reflorestamentos, vegetação de drenagem e culturas perenes, em virtude do grande aumento das áreas cultivadas com cana-de-açúcar que, em 1995 ocupava 66 $\%$ da área (Tabela 2).

Pode-se observar, também na tabela 2, a diminuição da área da represa devido ao assorreamento causado pela erosão, revelando os problemas existentes relativos à conservação dos solos.

O uso atual das terras da microbacia com cana-de-açúcar (Figura 4) é conseqüência direta dos incentivos oferecidos na década de oitenta pelo programa Proálcool. 
Tabela 2: Dimensão das áreas de uso das terras na Microbacia Hidrográfica do Córrego do Ceveiro de 1962-1995 (Fiorio, 1998).

\begin{tabular}{|c|c|c|c|c|}
\hline \multirow[b]{2}{*}{ Uso da Terra } & \multicolumn{4}{|c|}{ Ano/Escala } \\
\hline & 1962 & 1965 & 1978 & 1995 \\
\hline Cana-de-açúcar & 318,24 & 151,68 & 524,48 & 1319,64 \\
\hline Cultura anual & 633,44 & 835,72 & 226,64 & 2,96 \\
\hline Pasto & 289,72 & 281,88 & 558,56 & 96,4 \\
\hline Pasto sujo & 288,92 & 247,28 & 282,20 & 181,24 \\
\hline Reflorestamento & 293,60 & 230,88 & 267,96 & 120,12 \\
\hline Mata & 45,08 & 32,4 & 31,24 & 134,08 \\
\hline Vegetação de drenagem & 126,92 & 202,24 & 76,24 & 91,28 \\
\hline Área urbana & 2,6 & 8,32 & 11,44 & 39,16 \\
\hline Cultura perene & 1,88 & 0 & 0 & 0 \\
\hline Represa & 0 & 0 & 11,64 & 5,52 \\
\hline Total & 1990,40 & 1990,40 & 1990,40 & 1990,40 \\
\hline
\end{tabular}




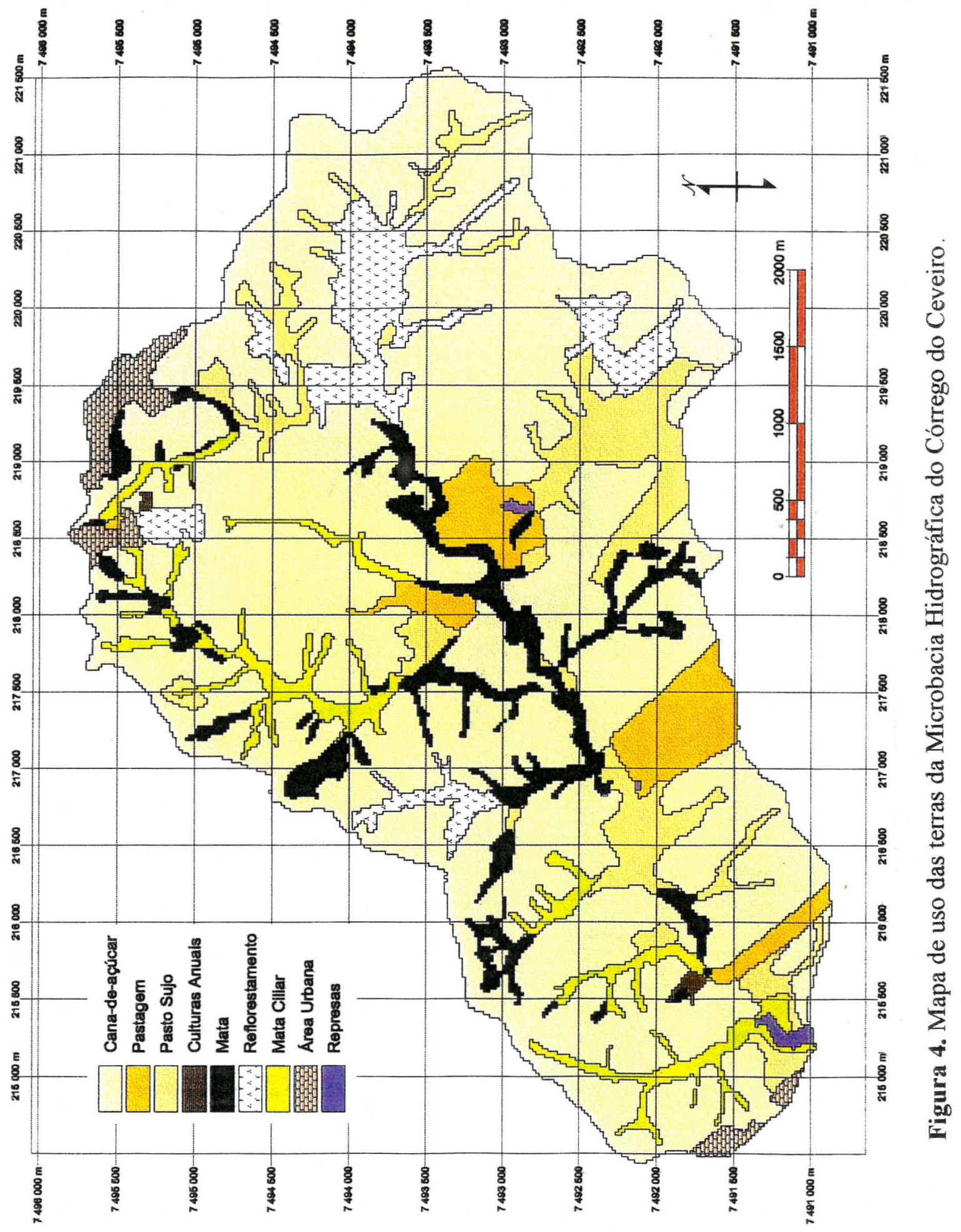




\subsubsection{Dados analíticos}

Para a avaliação das terras da MHCC pelo SCCUT, um banco de dados previamente elaborado foi utilizado. Nesse banco de dados além dos resultados de análises químicas e físicas de amostras de terra coletadas nos perfis e tradagens executadas na área, havia também informações relativas à profundidade efetiva dos pontos amostrados. Esse banco de dados, composto de 12 perfis e 196 tradagens, foram georreferenciados para interrelacionar o ponto de amostragem com a unidade pedológica a que pertencem, mediante a elaboração de um mapa de localização.

\subsubsection{Mapas}

Os mapas utilizados para o início deste estudo foram gerados utilizando informações previamente existentes da MHCC:

a) mapa planialtimétrico na escala 1:10.000;

b) mapa de classes de declive na escala 1:10.000;

c) mapa pedológico na escala 1:10.000;

d) mapa de uso atual das terras na escala 1:10.000;

e) mapa de localização das tradagens e perfis na escala 1:10.000.

Os mapas confeccionados para a análise dos resultados do presente trabalho foram digitalizados com o programa Autocad e posteriormente trabalhados no SIG Idrisi (Eastman, 1992), que utiliza uma estrutura raster cujas imagens foram produzidas em pixel de $20 \mathrm{~m} \times 20 \mathrm{~m}$. O georreferenciamento utilizou o sistema de coordenadas Universal Transversa de Mercador (UTM).

\subsubsection{Avaliadores participantes}

O contato inicial de pedido de contribuição científica consistiu do envio de 26 cartas a diferentes engenheiros agrônomos de todas as regiões do Brasil que utilizam o SCCUT como ferramenta de trabalho para atender a variados objetivos. Destas, 
para a realização da classificação. Enviados os materiais solicitados, retornaram 7 classificações da capacidade de uso das terras da MHCC, cuja identificação dos profissionais encontra-se na Tabela 5. De acordo com essa tabela, existem dois grupos distintos de profissionais participantes. Os três primeiros são professores/pesquisadores ligados diretamente ao planejamento e conservação de solos; já os quatro últimos, pertencentes a diferentes superintendências do INCRA, trabalham com a avaliação de imóveis rurais para fins de valoração de terras, em processos de desapropriação. Assim, tem-se nas classificações de capacidade de uso das terras, dois enfoques distintos na interpretação dos parâmetros avaliados.

Tabela 3. Identificação dos profissionais avaliadores.

\begin{tabular}{|c|c|c|}
\hline Profissional & Cargo & Area de conhecimento \\
\hline $\begin{array}{l}\text { Geraldo Victorino de França } \\
\text { (avaliador } 1 \text { ) }\end{array}$ & $\begin{array}{l}\text { Professor aposentado, Depto. de } \\
\text { Ciência do Solo, Escola Superior de } \\
\text { Agricultura "Luiz de Queiroz"- } \\
\text { Universidade de São Paulo. }\end{array}$ & $\begin{array}{l}\text { Fotointerpretação pedológica, } \\
\text { planejamento de uso da terra e } \\
\text { conservação do solo. }\end{array}$ \\
\hline $\begin{array}{l}\text { Glaucio Roloff } \\
\text { (avaliador 2) }\end{array}$ & $\begin{array}{l}\text { Professor adjunto do Depto. de } \\
\text { Solos do Setor de Ciências } \\
\text { Agrárias- Universidade Federal do } \\
\text { Paraná.. }\end{array}$ & $\begin{array}{l}\text { Conservação e manejo de solos, } \\
\text { planejamento de uso da terra e } \\
\text { modelagem para estimativa de } \\
\text { erosão. }\end{array}$ \\
\hline $\begin{array}{l}\text { Isabella Clerici De Maria } \\
\text { (avaliador 3) }\end{array}$ & $\begin{array}{l}\text { Pesquisadora cientifica do Centro } \\
\text { de Solos e Recursos } \\
\text { Agroambientais do Instituto } \\
\text { Agronômico de Campinas (IAC). }\end{array}$ & Conservação e manejo de solos. \\
\hline $\begin{array}{l}\text { Marcel Chacon Costa } \\
\text { (avaliador 4) }\end{array}$ & $\begin{array}{l}\text { Engenheiro Agrônomo, chefe do } \\
\text { grupo de desapropriação e } \\
\text { aquisição, INCRA da Paraíba. }\end{array}$ & $\begin{array}{l}\text { Reforma agrária, avaliação de } \\
\text { imóveis rurais e projetos de } \\
\text { investimento agropecuário. }\end{array}$ \\
\hline $\begin{array}{l}\text { João Carlos Machado } \\
\text { (avaliador 5) }\end{array}$ & $\begin{array}{l}\text { Engenheiro Agrônomo, INCRA de } \\
\text { São Paulo. }\end{array}$ & Avaliação de imóveis rurais. \\
\hline $\begin{array}{l}\text { Paulo Canuto } \\
\text { (avaliador 6) }\end{array}$ & $\begin{array}{l}\text { Engenheiro Agrônomo, INCRA de } \\
\text { Rondônia e Tocantins. }\end{array}$ & $\begin{array}{l}\text { Vistoria, avaliação e } \\
\text { desapropriação de imóveis rurais. }\end{array}$ \\
\hline $\begin{array}{l}\text { Ismael Viriato de Souza } \\
\text { (avaliador } 7 \text { ) }\end{array}$ & $\begin{array}{l}\text { Engenheiro Agrônomo, INCRA do } \\
\text { Rio Grande do Norte. }\end{array}$ & $\begin{array}{l}\text { Extensão rural, cartografia e } \\
\text { avaliação de imóveis narais. }\end{array}$ \\
\hline
\end{tabular}




\subsection{Métodos}

Para a obtenção de informações que permitissem a análise da subjetividade do SCCUT, com relação a variação proporcionada, executou-se um roteiro de atividades que consistiam do procedimento de coleta e análise de classificações da capacidade de uso das terras executadas por diferentes profissionais que utilizam o sistema para algum objetivo específico.

\subsubsection{Procedimento de coleta de dados}

\subsubsection{Contato com os avaliadores}

Com o intuito de executar esta fase foram contactados diversos engenheiros agrônomos de diferentes regiões do Brasil que utilizam o SCCUT para os mais variados objetivos. Este contato foi realizado por carta composta por duas partes distintas. A primeira foi um pedido amigável de contribuição científica para uma pesquisa de pósgraduação, com a execução da classificação da capacidade de uso das terras da MHCC. A segunda parte, no caso de uma resposta afirmativa à solicitação, consistia de uma lista de materiais existentes sobre a microbacia, dentre os quais os profissionais deveriam escolher aqueles que achassem necessários para a classificação. Essa lista era composta pelos mapas pré-existentes da área (planialtimétrico, classes de declividade, pedológico, uso atual e localização de tradagens e perfis, na escala 1:10.000), seus banco de dados analíticos, fotografias aéreas pancromáticas verticais na escala 1:25.000 datadas de junho/95 e a proposta de uma visita à $\mathrm{MHCC}$ a ser agendada posteriormente, bem como espaço reservado para a solicitação de outro tipo de material. As solicitações retornaram por carta resposta previamente postada, enviada com a correspondência inicial.

\subsubsection{Envio do material}

O material solicitado foi preparado e enviado aos colaboradores com uma segunda carta que consistiu de um pedido de retorno da classificação no período de quinze dias a partir do recebimento da correspondência. Essa carta enfatizou ainda que as classificações deveriam ser feitas de acordo com a metodologia que cada profissional estava acostumado a trabalhar, bem como sua forma de resposta, deixando livre a 
escolha dos procedimentos que fazem parte da definição da classificação das terras em capacidade de uso.

\subsubsection{Retorno das classificações}

As classificações enviadas vieram em forma de mapas e grades de decisão acompanhadas por um pequeno memorial descritivo, ou somente memorial descritivo. Para homogeneizar a forma de apresentação das classificações, as grades de decisão foram convertidas para mapas através do procedimento de sobreposição de imagens proporcionado pelo SIG Idrisi. Os mapas utilizados para essa conversão foram o de classes de declividade e de solos. Os colaboradores que enviaram apenas memorial descritivo foram descartados dos procedimento de análise de imagens, pois não informaram as relações definidas entre declividade e solos.

\subsubsection{Análise das classificações da capacidade de uso das terras}

\subsubsection{Análise das concordâncias espaciais}

Uma das formas de avaliação da subjetividade do SCCUT foi a comparação entre as diferentes classificações enviadas pelos avaliadores. Como estas estavam em forma de imagens, houve necessidade de utilização de uma metodologia de comparação para esse tipo de material. Assim, para a análise espacial das classificações de capacidade de uso das terras foi utilizado o parâmetro Kappa (k).

Entre os métodos existentes para estimar a concordância de mapas, o mais indicado é a análise multivariada discreta. Esta análise é baseada em matrizes de erros, também chamadas de matrizes de confusão ou tabela de contingência (Tabela 3). Três técnicas de análise fazem parte da análise multivariada discreta: normalização, parâmetro Kappa e exame simultâneo dos fatores (Congalton et al., 1983). Segundo Ponzoni \& Almeida (1996), dos três métodos citados, o parâmetro k é o mais amplamente utilizado. O parâmetro $\mathrm{k}$ considera toda a matriz de erro, destacando sua facilidade no cruzamento de mapas temáticos dispostos em forma digital, verificando a concordância existente, pixel a pixel (Ponzoni \& Almeida, 1996). 
Tabela 4. Exemplo da disposição dos dados em uma matriz de erros.

\begin{tabular}{|c|c|c|c|c|c|c|c|}
\hline \multirow[b]{2}{*}{ Classif. 2} & \multicolumn{6}{|c|}{ Classificação 1} & \multirow[b]{2}{*}{ Totais } \\
\hline & A & B & C & D & E & $F$ & \\
\hline A & $\overline{\mathbf{A A}}$ & $\overline{B A}$ & $\mathrm{CA}$ & $\overline{\mathrm{DA}}$ & $\overline{\mathrm{EA}}$ & FA & \\
\hline B & $\mathrm{AB}$ & BB & CB & DB & EB & FB & \\
\hline C & $\mathrm{AC}$ & $\mathrm{BC}$ & CC & $\mathrm{DC}$ & $\mathrm{EC}$ & FC & \\
\hline D & $\mathrm{AD}$ & BD & CD & DD & ED & FD & \\
\hline E & $\mathrm{AE}$ & $\mathrm{BE}$ & $\mathrm{CE}$ & $\mathrm{DE}$ & EE & FE & \\
\hline F & $\mathrm{AF}$ & $\mathrm{BF}$ & CF & $\mathrm{DF}$ & EF & $\mathbf{F F}$ & \\
\hline
\end{tabular}

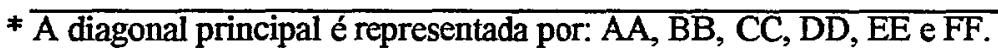

Segundo Congalton et al. (1983) o parâmetro $\mathrm{k}$ é calculado da seguinte forma:

$$
k=\frac{\theta_{1}-\theta_{2}}{1-\theta_{2}}
$$

Onde:

$$
\begin{gathered}
\theta_{1}=\frac{\sum_{i-1}^{r} x_{i j}}{N} \\
\theta_{2}=\frac{\sum_{i=1}^{r}\left(x_{i+} \cdot x_{+j}\right)}{N^{2}}
\end{gathered}
$$

$\mathrm{r} \rightarrow$ número de linhas da matriz de erros;

$\mathrm{x}_{\mathrm{ij}} \rightarrow$ número de observações na linha $\mathrm{i}$ e coluna $\mathrm{j}$ que referem-se a diagonal principal; 
$\mathrm{x}_{\mathrm{i}+}$ e $\mathrm{x}_{+\mathrm{j}} \rightarrow$ os totais marginais da linha i e da coluna $\mathrm{j}$, respectivamente;

$\mathrm{N} \rightarrow$ número total de observações da matriz de erros.

Esses mesmos autores ressaltam que a situação ideal, ou seja, o índice máximo de concordância é obtido quando todos os elementos da matriz fora da diagonal principal forem iguais a zero.

Os valores resultantes do parâmetro $\mathrm{k}$ variam de valores menores que zero a um, sendo os inferiores a zero indicativos de nenhuma similaridade, os maiores do que zero $\mathrm{e}$ mais próximos, indicativos de baixa concordância e os próximos a um, de maior concordância (Ortiz, 1993). A qualidade do parâmetro $\mathrm{k}$ foi determinada por Landis \& Koch (1977), distribuindo-os em faixas de valores (Tabela 5).

Tabela 5. Qualidade do parâmetro Kappa (k), segundo sua faixa de concordância (Landis \& Koch, 1977).

\begin{tabular}{cc}
\hline Kappa & Qualidade \\
\hline$<0,0$ & péssima \\
$0,0-0,2$ & ruim \\
$0,2-0,4$ & razoável \\
$0,4-0,6$ & boa \\
$0,6-0,8$ & muito boa \\
$0,8-1,0$ & excelente \\
\hline
\end{tabular}

Landis \& Koch (1977) ao definirem os intervalos do parâmetro k, objetivaram a análise de imagens orbitais. Pode-se observar que a amplitude de qualificação dessas faixas de valores representam qualidades altas. Exemplo disso é um $k=0,5$ que corresponde a $50 \%$ de coincidência entre os elementos de duas imagens, sendo qualificado como uma boa concordância. Como em classificações da capacidade de uso das terras ễão indesejáveis discordâncias tão altas entre os elementos de duas 
avaliações, foi elaborada uma nova faixa de valores do parâmetro $k$ que atendam as exigências dos objetivos para os quais o SCCUT tem sido utilizado (Tabela 6).

Tabela 6. Qualidade do parâmetro Kappa (k), segundo sua faixa de concordância para a análise do SCCUT.

\begin{tabular}{cc}
\hline Kappa & Qualidade \\
\hline$<0,3$ & péssima \\
$0,3-0,5$ & ruim \\
$0,5-0,8$ & razoável \\
$>0,8$ & boa \\
\hline
\end{tabular}

\subsubsection{Análise das concordâncias globais}

Com o intuito de analisar os dados de área estabelecidos nas diferentes classificações apresentadas, foram utilizados parâmetros estatísticos que norteiam a variação de dados experimentais devido a fatores não controláveis. Para tanto foram utilizados o intervalo de confiança para a média e o coeficiente de variação.

O intervalo de confiança para a média expressa uma idéia da precisão da estimativa da média, em termos probalísticos. De acordo com Nogueira (1997) foi calculado conforme a seguinte equação:

$$
I C(\mu)_{(1-\alpha)} \Rightarrow \mu \pm z . S(\mu)
$$

$(1-\alpha) \rightarrow$ o coeficiente de confiança;

$\mu \rightarrow$ a estimativa da média;

$S(\mu) \rightarrow$ o desvio padrão da média, associado a $(n-1)$ graus de liberdade; 
$z \rightarrow$ variável independente da equação de distribuição normal. No caso dos cálculos utilizou-se o valor $z=1,96$ representando um nível de significância de $95 \%$.

O coeficiente de variação, medida de dispersão que expressa percentualmente o desvio padrão por unidade da média, foi calculado segundo Nogueira (1997), da seguinte forma:

$$
C V=\frac{d p}{\mu} 100
$$

$\mathrm{dp} \rightarrow$ estimativa do desvio padrão;

$\mu \rightarrow$ estimativa da média.

O coeficiente de variação nada mais é do que o desvio padrão dado em porcentagem da média. 


\section{RESULTADOS E DISCUSSÃO}

\subsection{Decisão sobre o material necessário para a classificaçã̀o}

A decisão dos avaliadores, quanto ao material necessário para a classificação das terras da MHCC em capacidade de uso encontra-se na tabela 7. Essa tabela apresenta o primeiro resultado da subjetividade intrínseca ao SCCUT. Todos os avaliadores escolheram materiais diferenciados para execução da classificação e apenas um pediu informações adicionais referentes ao clima que, segundo Lepsch et al. (1991) é um dos itens importantes de avaliação. Outra observação foi a da falta de necessidade dos avaliadores em irem até a área de estudo para observações de campo, antes da execução da classificação. No caso do avaliador 2 o pedido existiu mas não pode ser cumprido face o mesmo encontrar-se fora do país na época deste estudo. Já o avaliador 4 tentou minimizar a sua impossibilidade de viagem com a solicitação de fotografias da área. Apesar de ter solicitado uma visita à área, o avaliador 1 acabou por considerar desnecessária sua ida ao campo. Isso ocorreu devido ao fato deste avaliador pertencer à região onde encontra-se a área de estudo. 
Tabela 7. Solicitações de material para a classificação das terras da Microbacia Hidrográfica do Córrego do Ceveiro em classes de capacidade de uso.

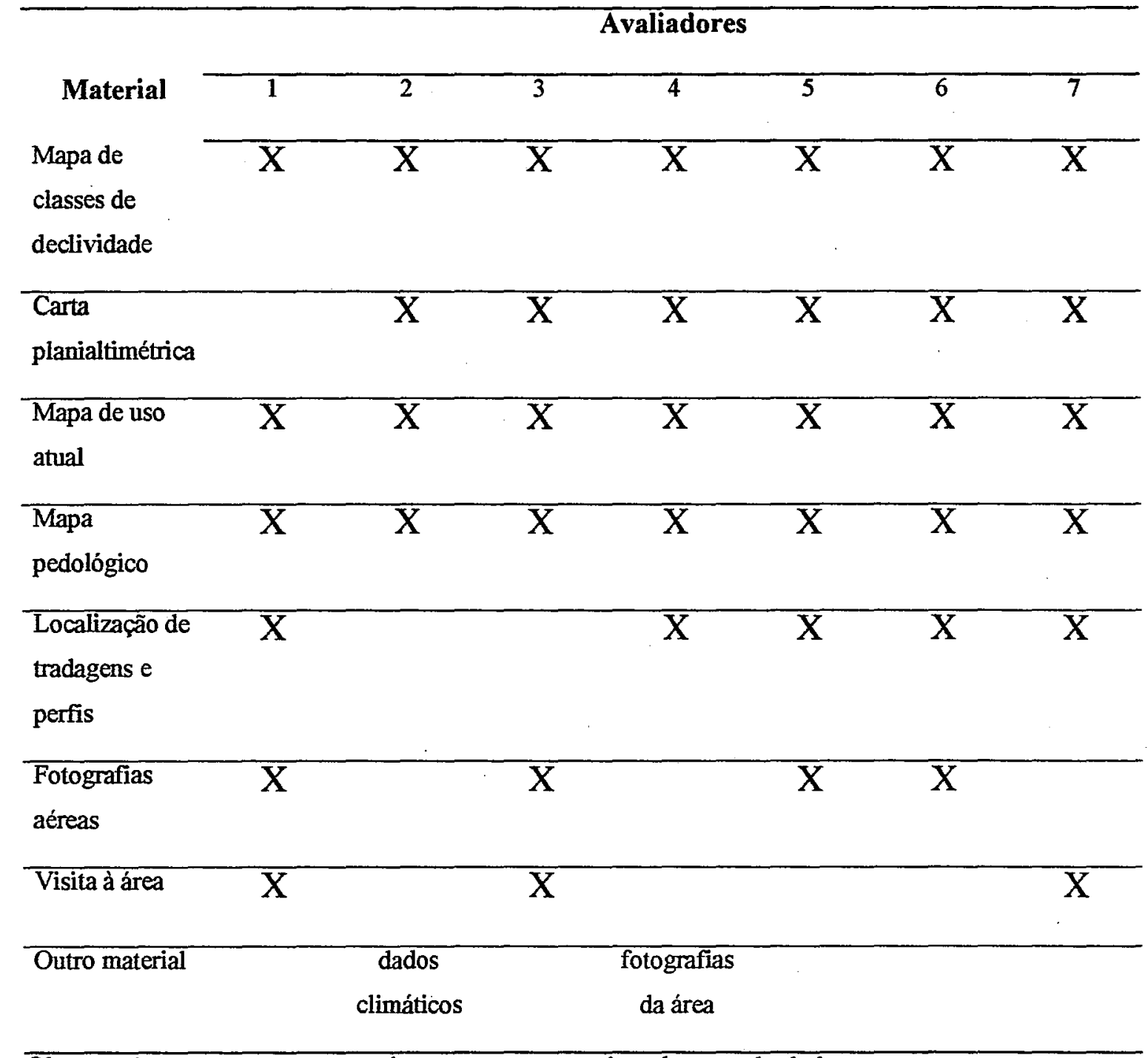

Observação: os mapas acompanharam seus respectivos bancos de dados.

\subsubsection{Observação dos avaliadores quanto ao material enviado}

Dos sete avaliadores que enviaram suas classificações, três contestaram a utilização do mapa de declividade gerado pelo SIG Idrisi para trabalhos de planejamento. Esse problema ocorreu face à forma pela qual o programa apresentou seu resultado gráfico. A limitação proporcionada pelo pixel, unidade básica de trabalho do programa além da metodologia de interpolação empregada, apresentam deficiências para 
a geração de um modelo digital do terreno adequado a este tipo de trabalho. Dessa forma o resultado gráfico acabou sugerindo uma conformação muito detalhada do mapa de classes de declividade, acarretando em excesso de informações e limites de declividade muito bruscos, dificultando a tomada de decisão para a definição da classificação da capacidade de uso das terras.

Como este fato foi percebido no retorno da primeira classificação pertencente ao avaliador 1, foi solicitado que este elaborasse um mapa de classes de declividade da MHCC, de acordo com os padrões necessários para um trabalho de planejamento agrícola. Após a elaboração do mapa, o mesmo foi digitalizado para uma comparação entre as conformações (Figuras $5 \mathrm{a}$ e $5 \mathrm{~b}$ ) e concordâncias através da análise da matriz de erros (Tabela 8).

O mapa de classes de declividade executado manualmente através de ábaco, possui uma configuração com áreas mais abrangentes e pouco retalhamento (Figura $5 b$ ). Sua concordância com o mapa gerado pelo Idrisi (Figura 5a), estimada pelo parâmetro k através dos dados da matriz de erros foi 0,46 , correspondente à uma qualidade de concordância considerada ruim. Observando a matriz de erros, percebe-se que a diagonal principal é a que possui a maior parte das áreas da classificação, com exceção das classes de declividade $2-5 \%$ e $>20 \%$. Nesse casos houve uma certa confusão na disposição das classes de declividade, ficando as maiores áreas ajustadas à classe mais próxima.

Essas respostas demonstram que, dependendo do objetivo do trabalho a ser realizado, há a necessidade de materiais diferenciados. Assim, em trabalhos de planejamento agrícola depende da experiência do profissional, a decisão de escolha do melhor material básico a ser utilizado, pois foi verificado que não são todas as situações que admitem a utilização de material gráfico gerado por um SIG. Adotou-se portanto, o mapa manual como mapa de classes de declividade básico para este estudo, sendo utilizado na formação dos mapas de classificação da capacidade de uso das terras, dos avaliadores que enviaram grades de decisão. 
Tabela 8. Matriz de erros da relação entre as áreas dos mapas de classes de declividade gerados manualmente e pelo Idrisi.

\begin{tabular}{|c|c|c|c|c|c|c|}
\hline \multirow{3}{*}{$\begin{array}{l}\text { Mapa } \\
\text { Idrisi }\end{array}$} & \multicolumn{5}{|c|}{ Mapa manual } & \multirow{3}{*}{ Totais } \\
\hline & $0-2 \%$ & $2-5 \%$ & $5-10 \%$ & $10-20 \%$ & $>20 \%$ & \\
\hline & & & & & & \\
\hline \multicolumn{7}{|c|}{ ha } \\
\hline $0-2 \%$ & $42,2(2,12)$ & $73,0 \quad(3,67)$ & $67,12(3,37)$ & $104,84(5,27)$ & $48,24(2,42)$ & $335,4(16,85)$ \\
\hline $2-5 \%$ & $18,44(0,93)$ & $50,72(2,55)$ & $64,08 \quad(3,22)$ & $17,68(0,89)$ & $2,72(0,14)$ & $153,64(7,73)$ \\
\hline $5-10 \%$ & $11,68(0,59)$ & $65,04(3,27)$ & $212,96(10,7)$ & $156,68(7,87)$ & $22,24(1,12)$ & $468,6(23,55)$ \\
\hline $10-20 \%$ & $4,08 \quad(0,20)$ & $20,76(1,04)$ & $134,6(6,76)$ & $474,5(23,84)$ & $223,7(11,24)$ & $857,6(43,08)$ \\
\hline$>20 \%$ & $0,40(0,02)$ & $0,88(0,04)$ & $3,36(0,17)$ & $40,96(2,06)$ & $84,48(4,24)$ & $130,08(6,53)$ \\
\hline Totais & $7680(386)$ & $210,40(10,6)$ & $482,1(24,2)$ & $794,7(39,94)$ & $381,4(19,14)$ & 1990,4 \\
\hline
\end{tabular}




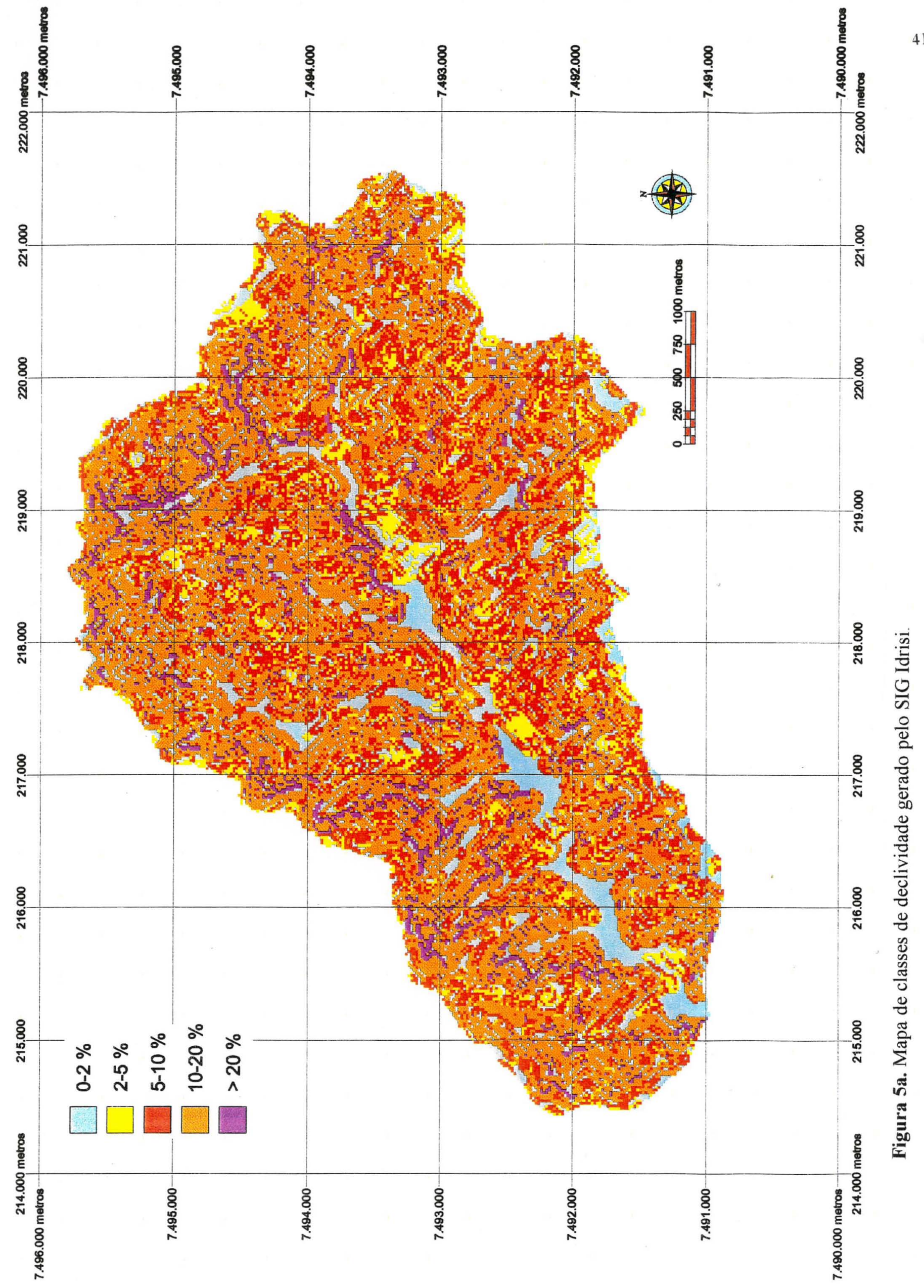




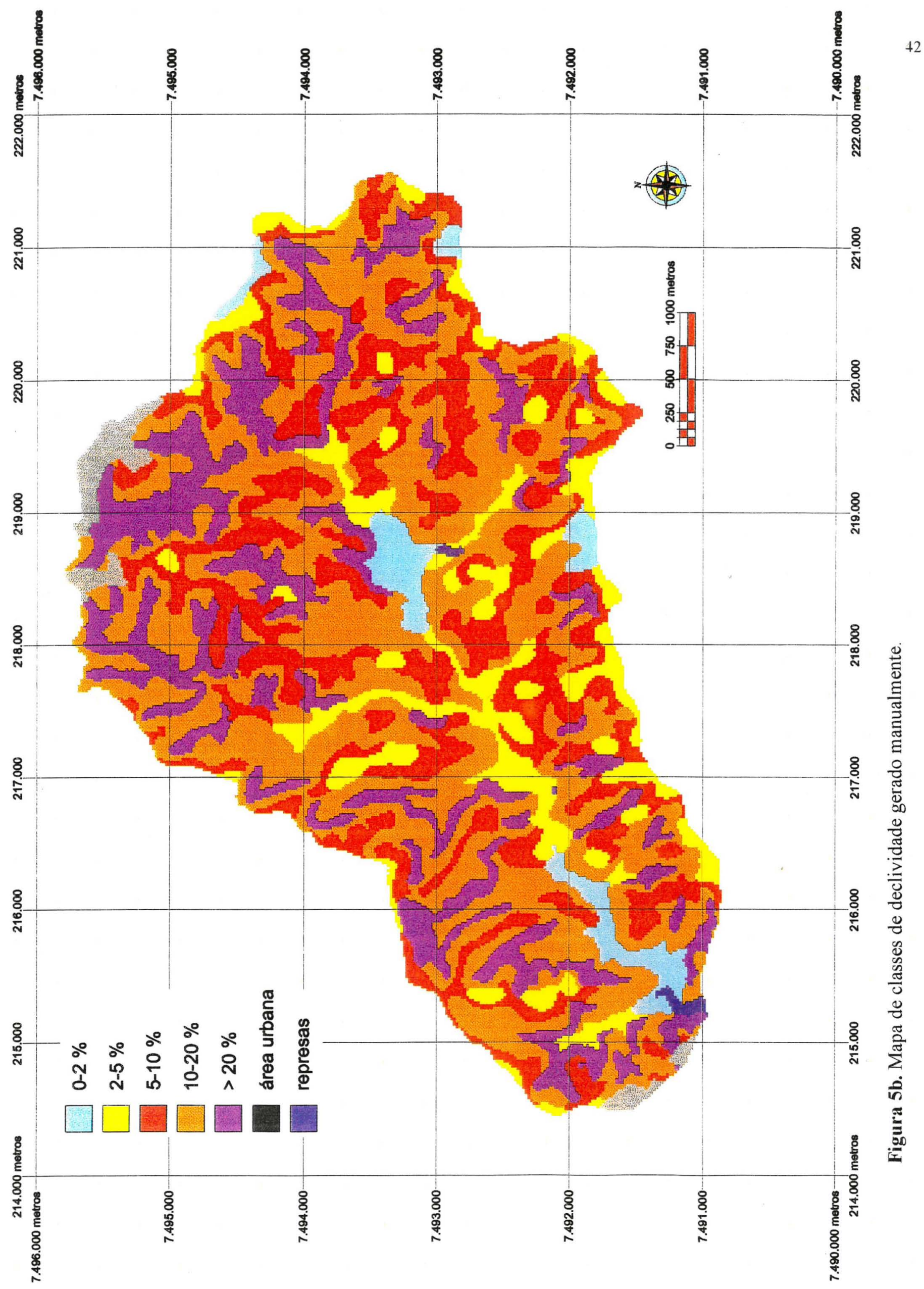




\subsection{Classificações da capacidade de uso das terras}

\subsubsection{Forma de apresentação}

A forma com que as classificações da capacidade de uso das terras foram apresentadas encontram-se na tabela 9.

Dos sete avaliadores, dois entregaram a classificação em forma de mapa acompanhado por memorial descritivo, três em forma de grade de decisão e dois em forma de memorial descritivo. A princípio, a maioria dos colaboradores discordou quanto a apresentação final da classificação que, segundo Lepsch et al. (1991), deve ser em forma de mapa. Dos que apresentaram em forma de grade de decisão, os avaliadores 2 e 3 justificaram a forma de sua apresentação devido à falta de tempo. Em contrapartida, para o avaliador 5 , trata-se de um procedimento normal de trabalho. Os avaliadores 6 e 7 apresentaram memoriais descritivos, onde as classificações estão definidas e relacionadas às porcentagens de áreas, procedimento este diretamente ligado a valoração de terras. Esta diferenciação na forma de apresentação dos resultados de classificação, principalmente dos dois últimos avaliadores, sugere duas hipóteses:

1. alguns usuários do SCCUT não possuem conhecimento total de sua metodologia, ou da interpretação dos seus critérios;

2. alguns usuários do SCCUT utilizam uma forma própria de avaliação dos critérios para a definição de classes de capacidade de uso, de acordo com os objetivos do trabalho, criando um sistema ramificado.

Houve certa discordância também no tocante à escolha do material básico de consulta para a classificação. Dos cinco colaboradores que informaram suas fontes de consulta, nem todos utilizam a metodologia mais recente. 
Tabela 9. Forma de apresentação das classificações da capacidade de uso das terras.

\begin{tabular}{|c|c|c|}
\hline Profissional & Forma de apresentação & Material utilizado para a classificação \\
\hline avaliador 1 & mapa e memorial descritivo & $\begin{array}{l}\text { Manual para Lev. Util. do Meio Físico e } \\
\text { Classif. de Terras no Sist. de Capacidade de } \\
\text { Uso (Lepsch et al., 1983) }\end{array}$ \\
\hline avaliador 2 & $\begin{array}{l}\text { grade de decisão e memorial } \\
\text { descritivo }\end{array}$ & $\begin{array}{l}\text { Manual para Lev. Util. do Meio Físico e } \\
\text { Classif. de Terras no Sist. de Capacidade de } \\
\text { Uso (Lepsch et al., 1991) }\end{array}$ \\
\hline avaliador 3 & $\begin{array}{l}\text { grade de decisão e memorial } \\
\text { descritivo }\end{array}$ & $\begin{array}{l}\text { Manual para Lev. Util. do Meio Físico e } \\
\text { Classif. de Terras no Sist. de Capacidade de } \\
\text { Uso (Lepsch et al., 1991) }\end{array}$ \\
\hline avaliador 4 & mapa e memorial descritivo & $\begin{array}{l}\text { Manual para Lev. Util. do Meio Físico e } \\
\text { Classif. de Terras no Sist. de Capacidade de } \\
\text { Uso (Lepsch et al., 1983) }\end{array}$ \\
\hline avaliador 5 & $\begin{array}{l}\text { grade de decisão e memorial } \\
\text { descritivo }\end{array}$ & não informou \\
\hline avaliador 6 & memorial descritivo & $\begin{array}{l}\text { Manual Brasileiro para Lev. da Capacidade de } \\
\text { Uso da Terra (Marques, 1971) }\end{array}$ \\
\hline avaliador 7 & memorial descritivo & não informou \\
\hline
\end{tabular}

\subsubsection{Mapas de classificação da capacidade do uso das terras}

Os mapas de classificação da capacidade de uso das terras dos avaliadores 1 e 4, podem ser observados nas figuras 6 e 7 , respectivamente. As classificações de capacidade de uso das terras dos avaliadores 2, 3 e 5, após sua conversão de grades de decisões para mapas, podem ser observadas nas figuras 8,9 e 10, respectivamente. As classificações dos avaliadores 6 e 7, não puderam ser convertidas em mapas, face a 
forma pela qual suas classificações foram apresentadas. As áreas das classificações proporcionadas pelos cinco primeiros avaliadores, encontram-se na tabela 10.

Tabela 10. Áreas das classificações da capacidade de uso das terras segundo os cinco primeiros avaliadores.

avaliadores

\begin{tabular}{cccccc} 
SCCUT * & $\mathbf{1}$ & $\mathbf{2}$ & $\mathbf{3}$ & $\mathbf{4}$ & $\mathbf{5}$ \\
\hline I & 9,16 & 14,04 & 7,32 & 0 & 0 \\
II & 62,92 & 123,04 & 127,96 & 167,36 & 41,64 \\
III & 354,20 & 318,80 & 220,12 & 483,64 & 278,16 \\
IV & 510,16 & 558,28 & 574,24 & 971,12 & 1540,16 \\
V & 43,84 & 31,08 & 0 & 0 & 31,20 \\
VI & 295,88 & 643,60 & 328,88 & 323,24 & 45,44 \\
VII & 669,20 & 256,52 & 686,84 & 0 & 0 \\
VIII & 0 & 0 & 0 & 0 & 8,76
\end{tabular}

* SCCUT: Sistema de Classificação da capacidade de uso das Terras.

Observações: 1. Nestas classificações não constam as áreas urbanas e represas, perfazendo uma área de avaliação de 1945,36ha.

2.0 avaliador 3 ressaltou em seu memorial descritivo que serão classe VIII as áreas que possuirem mata ou mata ciliar.

Os mapas de classificação da capacidade de uso das terras apresentados, mostram a diferença de interpretação dos avaliadores no tocante à definição dos critérios analisados. Os limites entre as classes de capacidade de uso ficaram evidentes na observação destes mapas. A concentração de manchas maiores de uma determinada classe ocorreu mais nos mapas pertencentes aos avaliadores 4 e 5 . Este último utilizou apenas as informações das unidades de solo, para a execução da grade de decisão da 
classificação da capacidade de uso das terras, incorrendo em generalização das classes escolhidas. Essa observação ficou mais ressaltada pelos valores de áreas constantes da tabela 10. Nesta, a maior parte da área, para estes dois avaliadores, foi classificada como classe de capacidade de uso IV, evidenciando uma sincronia na forma de definição da classificação. Em contrapartida, um maior detalhamento foi encontrado na definição das classes nos mapas dos demais avaliadores.

Os avaliadores 1, 2 e 3, apresentaram respostas bem próximas em suas classificações. Para estes as classes VI e VII foram responsáveis pela caracterização da capacidade de uso da maior parte da área de estudo. Houve alguma discordância em relação à definição da classe de capacidade de uso $\mathrm{V}$. Ocorreram ainda pequenas confusões entre classes de capacidade de uso vizinhas. Isto foi causado pela subjetividade intrínseca na forma pela qual a definição das classes é citada no SCCUT. A definições de palavras como simples, complexo e especial, utilizadas para distinguir diferenças entre classes, encontram-se deslocadas dos esquemas principais de consulta da metodologia, levando a possibilidade de várias interpretações distintas.

Os resultados também mostram que ocorreu uma tendência de raciocínio entre os três primeiros avaliadores e entre os dois últimos, onde o primeiro grupo utilizou as mesmas classes para classificar a área, com exceção do avaliador 3 que não utilizou a classe V. O segundo grupo coincidiu as maiores a classificação da maior parte da área nas classes III e IV.

Esses resultados mostram a variação existente na classificação de terras mediante a utilização SCCUT, por avaliadores distintos. 


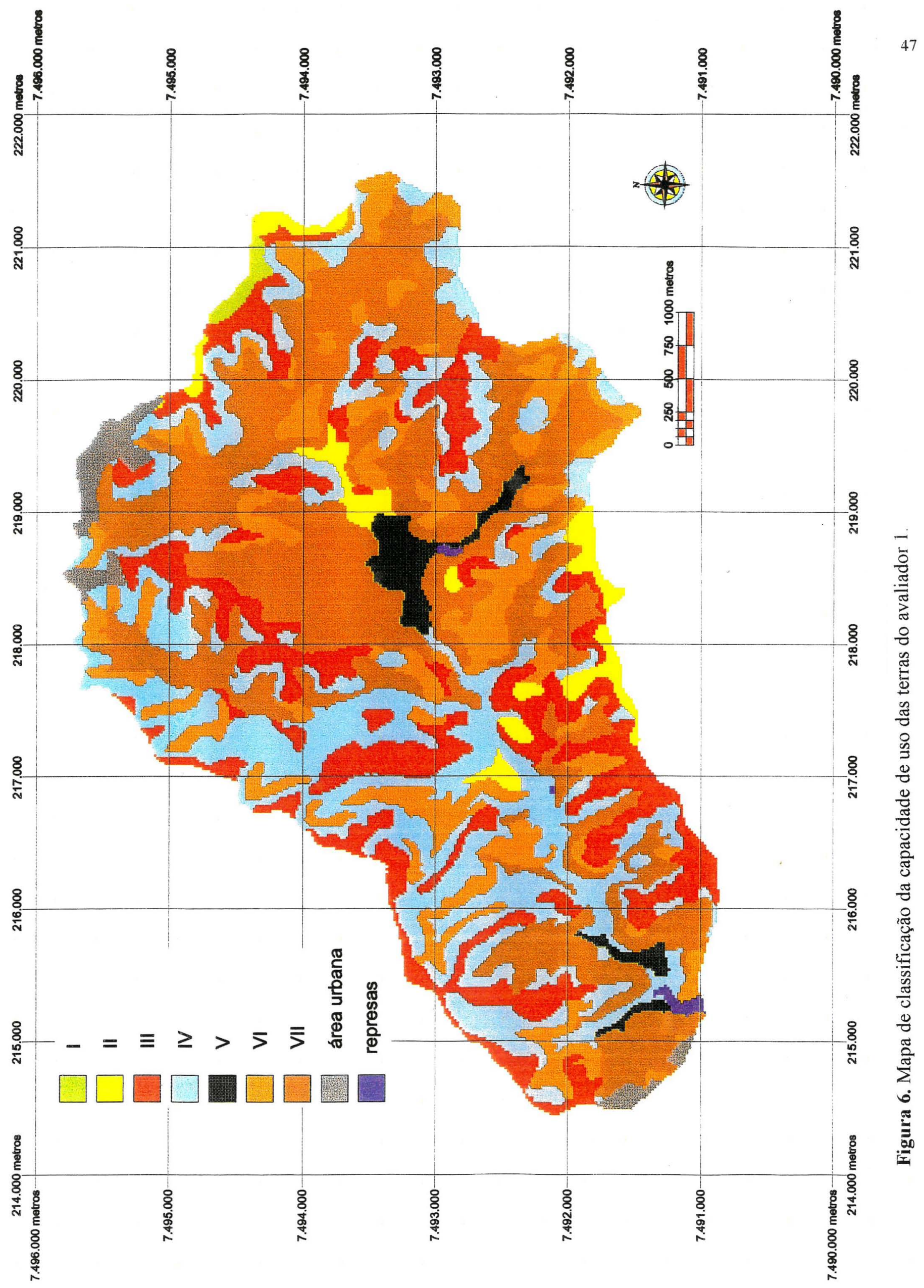




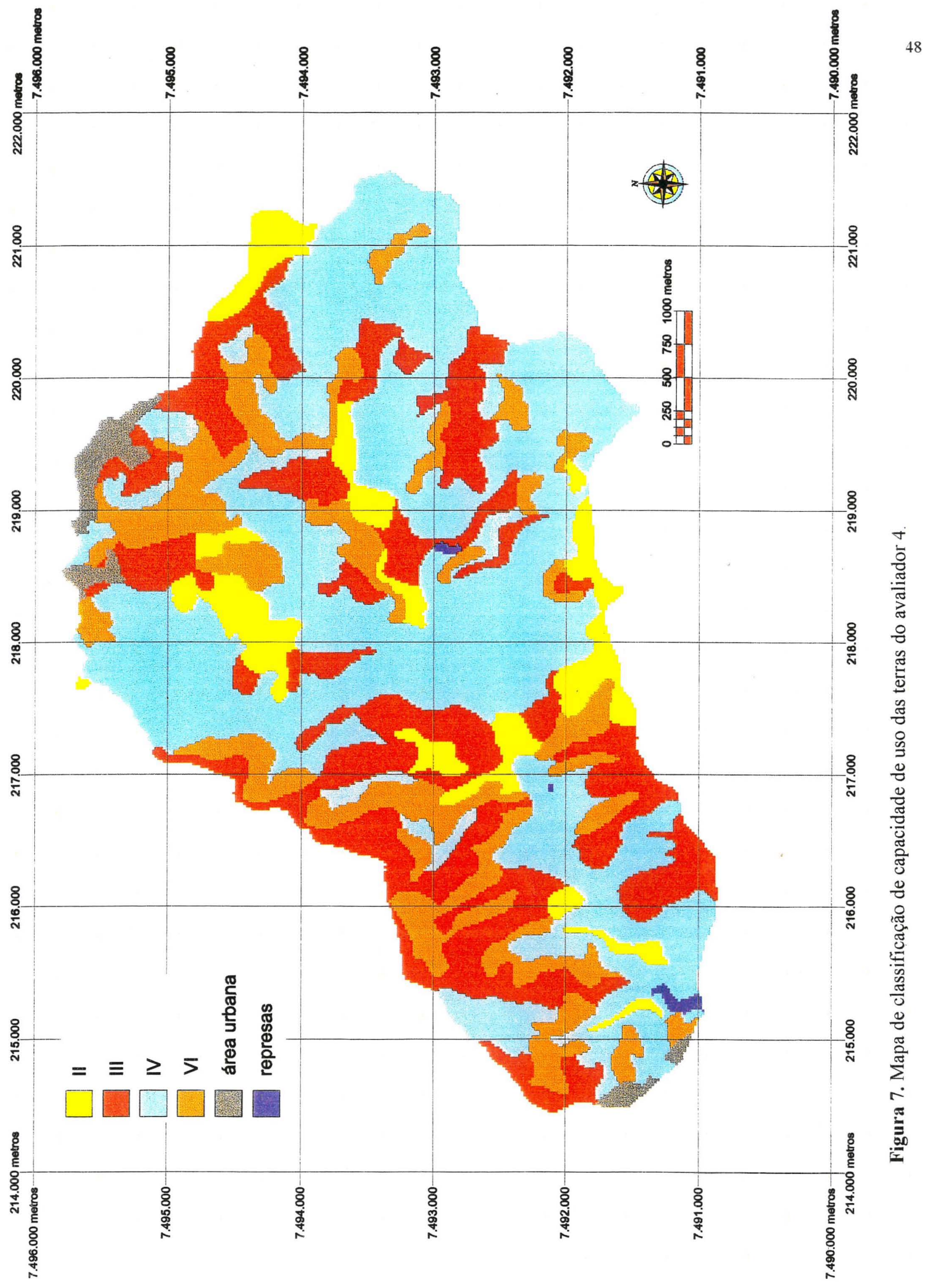




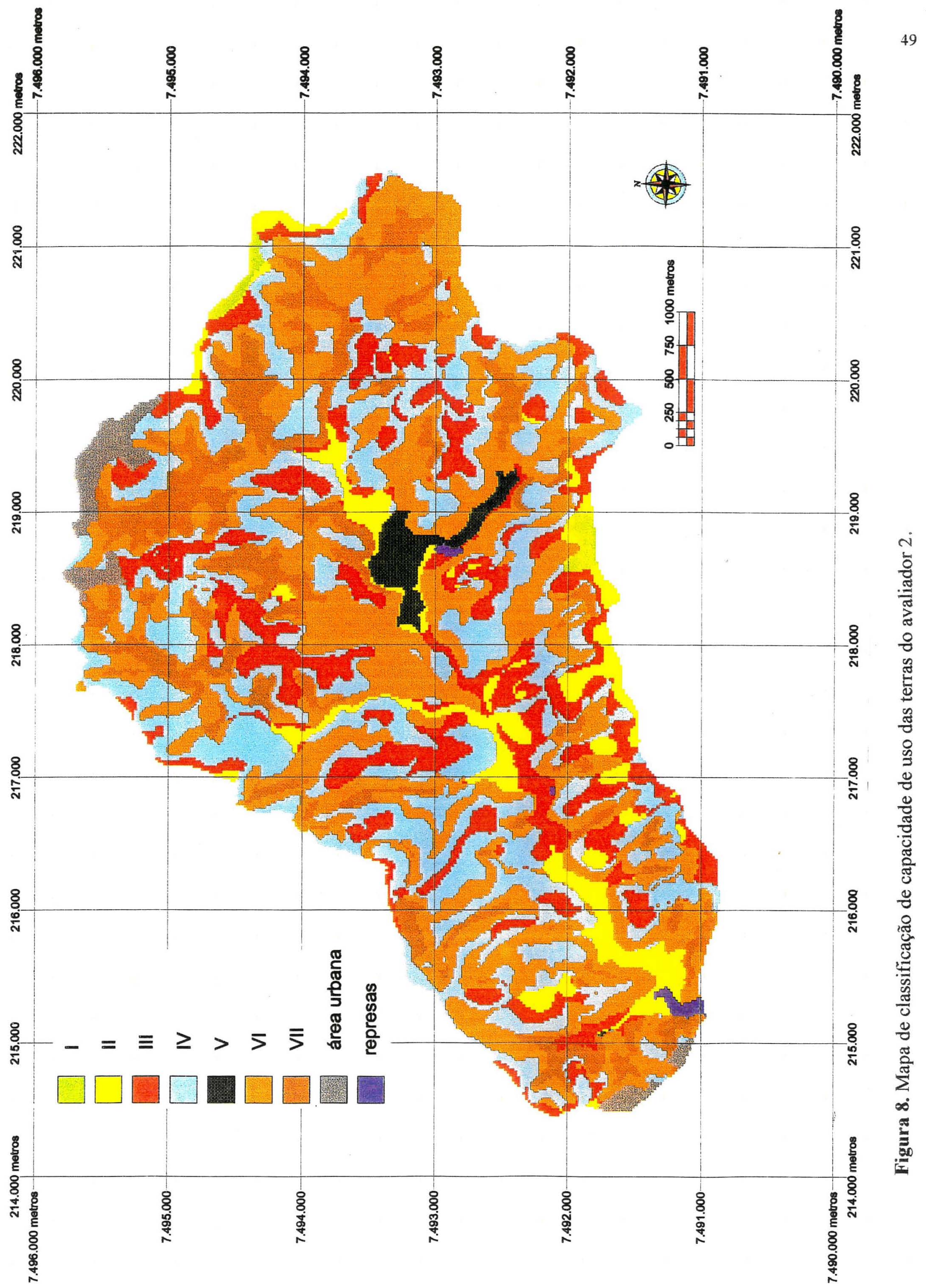




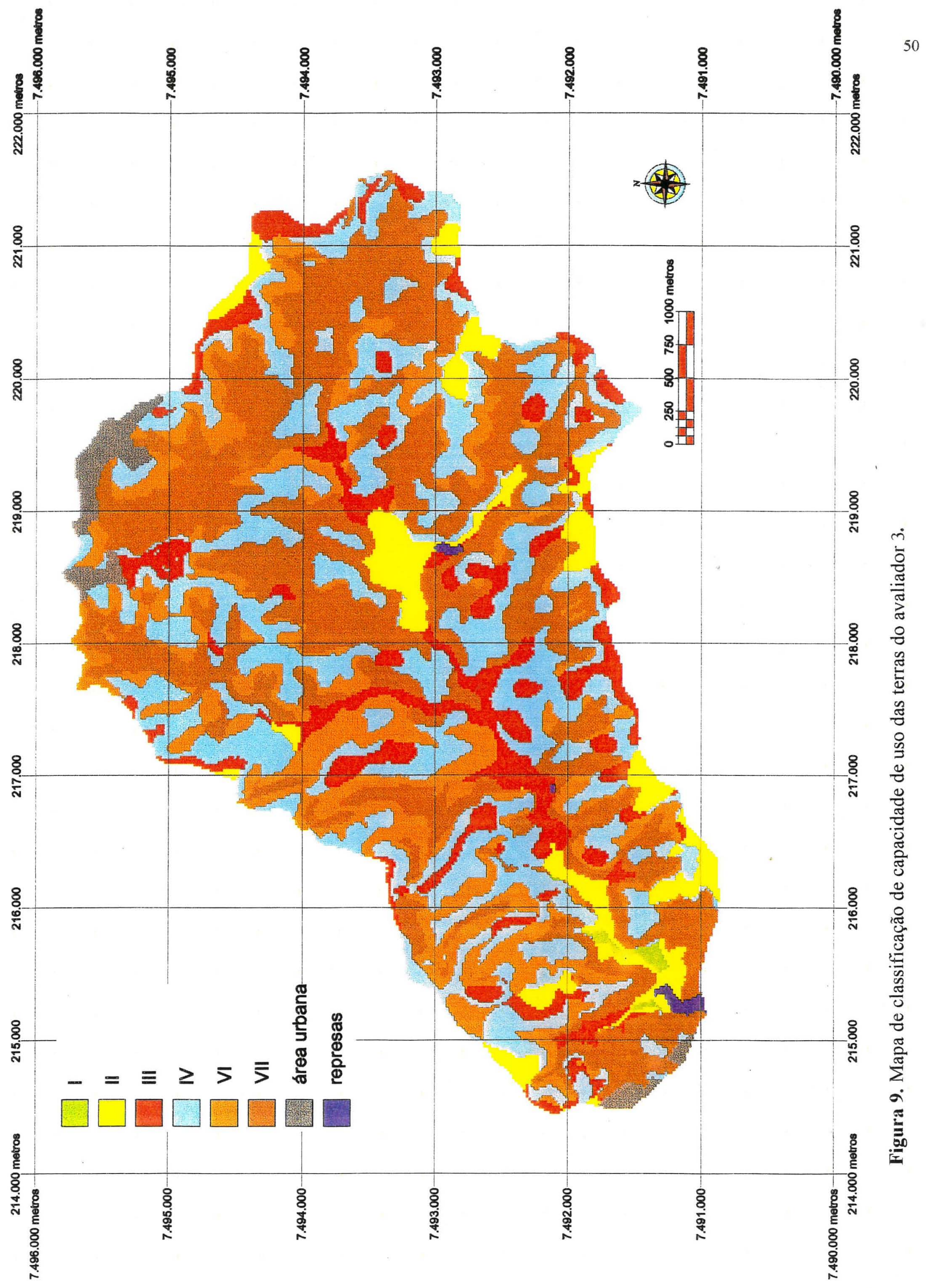




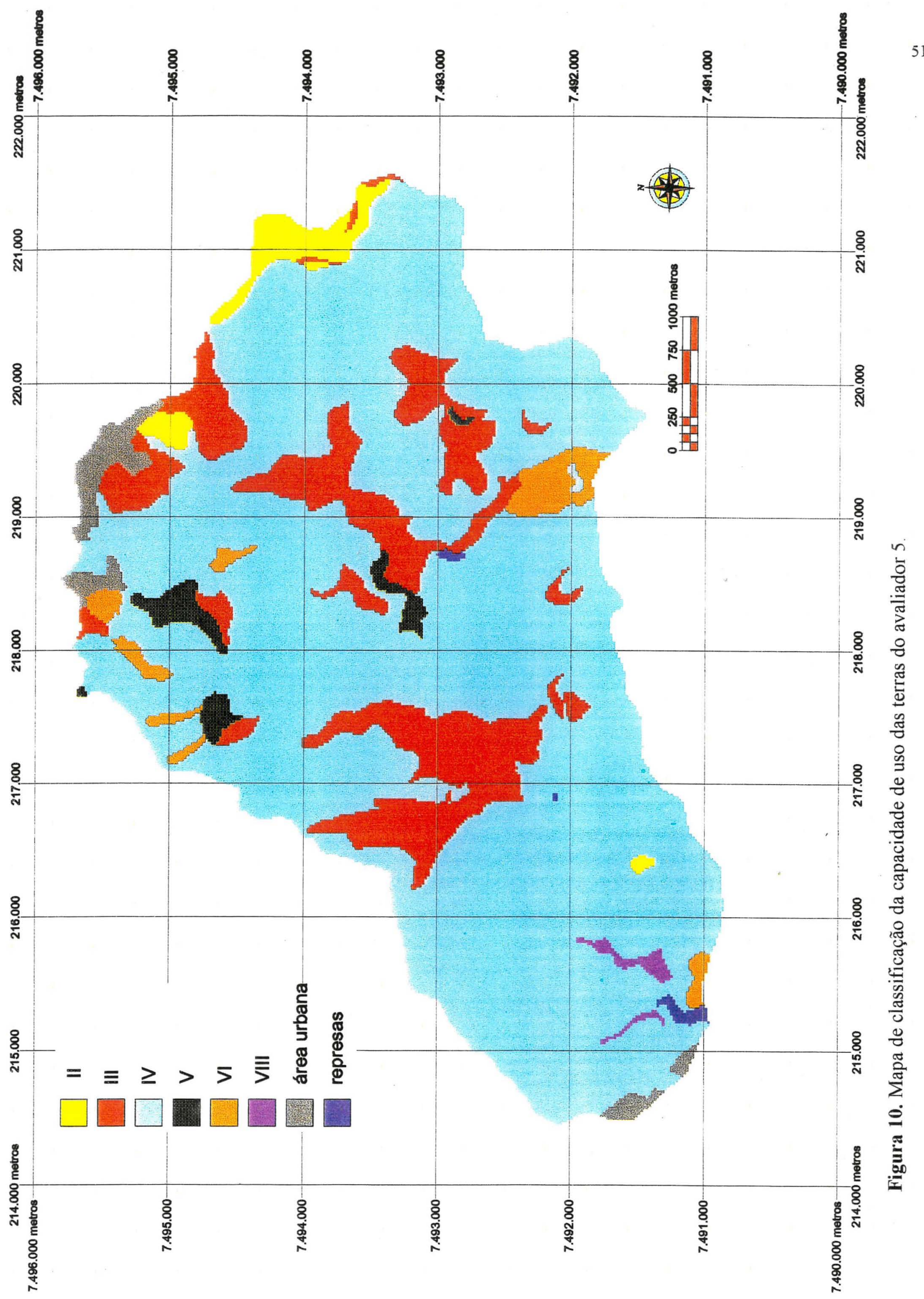




\subsection{Análise de concordância entre as diferentes classificações}

\subsubsection{Concordância das classificações em função do avaliador}

Para uma análise de concordância entre as distintas classificações de capacidade de uso das terras, foram executadas avaliações com relação à concordância espacial e global.

\subsubsection{Concordância espacial}

A concordância espacial avalia a coincidência na disposição dos elementos pertencentes a duas imagens. A análise de concordância espacial entre as classes de capacidade de uso das terras das diferentes classificações apresentadas foi executada pela sobreposição dos mapas, dois a dois. Para esta análise foram retirados os avaliadores que enviaram suas classificações sem o respectivo mapa, ou que não puderam ser convertidos, perfazendo um total de cinco classificações que serão submetidas à concordância espacial. Destas relações foram definidas as matrizes de erros, conforme as tabelas $11,12,13,14,15,16,17,18,19$ e 20. 
Tabela 11. Matriz de erros com as áreas da relação entre a classificação da capacidade de uso das terras dos avaliadores 1 e 2.

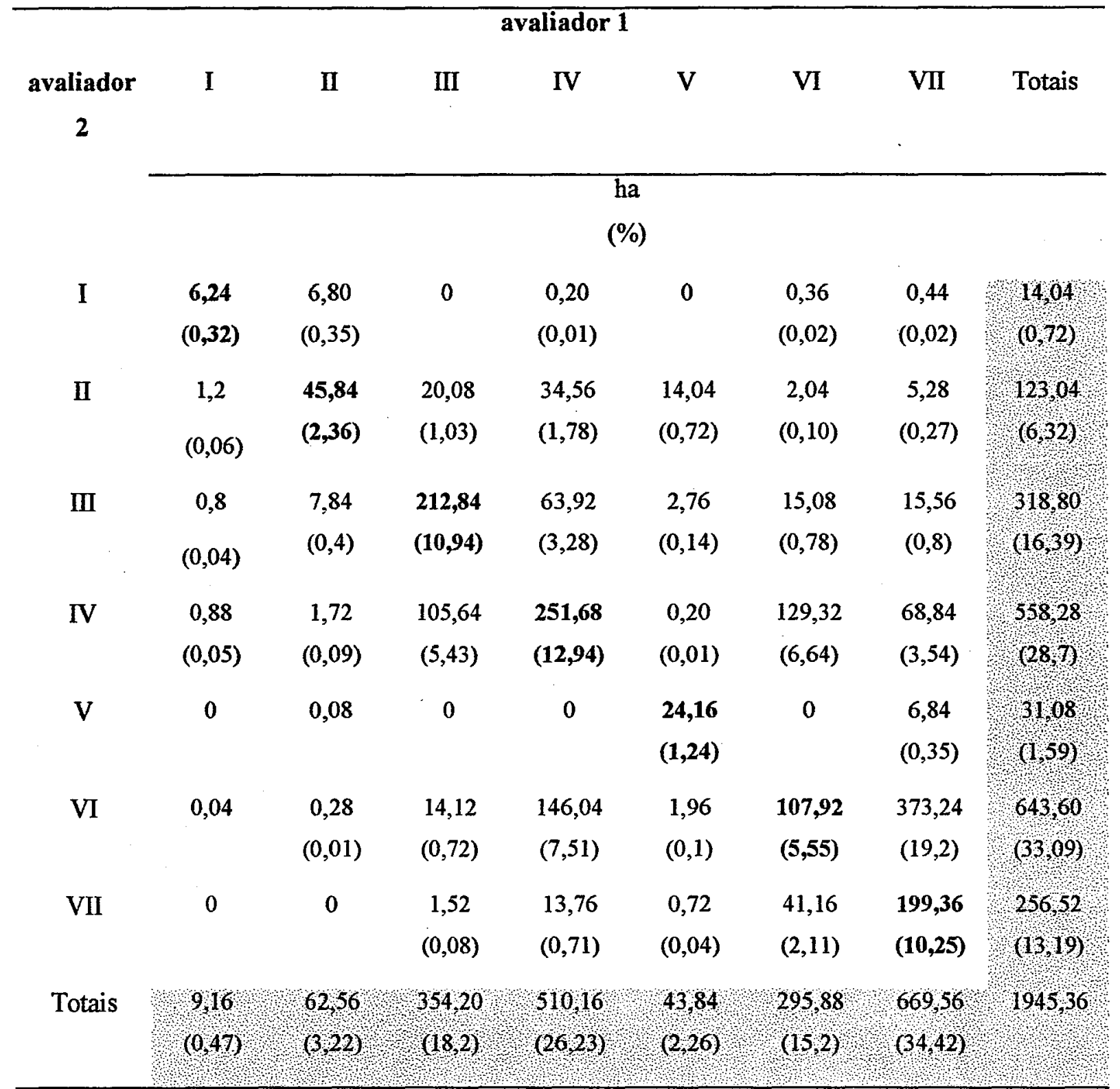

Observações: nesta matriz não constam as áreas urbanas e represas, perfazendo uma área de avaliação de 1945,36 ha.

$\mathrm{k}=0,44$ 
Tabela 12. Matriz de erros das áreas da relação entre a classificação da capacidade de uso das terras dos avaliadores 1 e 3 .

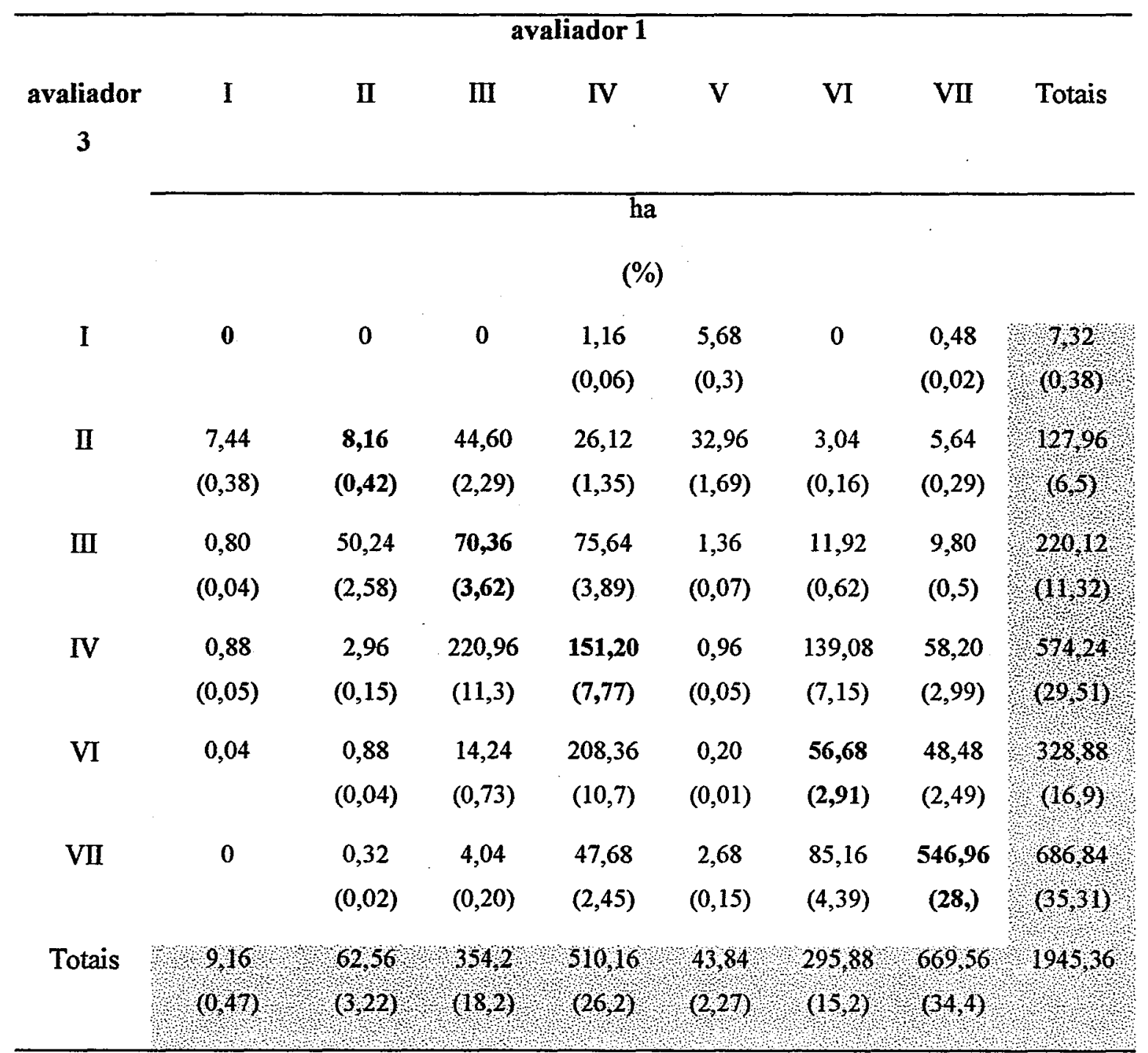

Observações: nesta matriz não constam as áreas urbanas e represas, perfazendo uma área de avaliação de 1945,36 ha.

$\mathrm{k}=0,43$ 
Tabela 13. Matriz de erros das áreas da relação entre a classificação da capacidade de uso das terras dos avaliadores 1 e 4 .

\section{avaliador 1}

$\begin{array}{lllllllllllll}\begin{array}{c}\text { avaliador } \\ 4\end{array} & \text { I } & \text { II } & \text { III } & \text { IV } & \text { V } & \text { VI } & \text { VII } & \text { Totais } \\ \text { ha } & & & & & & & & & \\ \end{array}$

$(\%)$

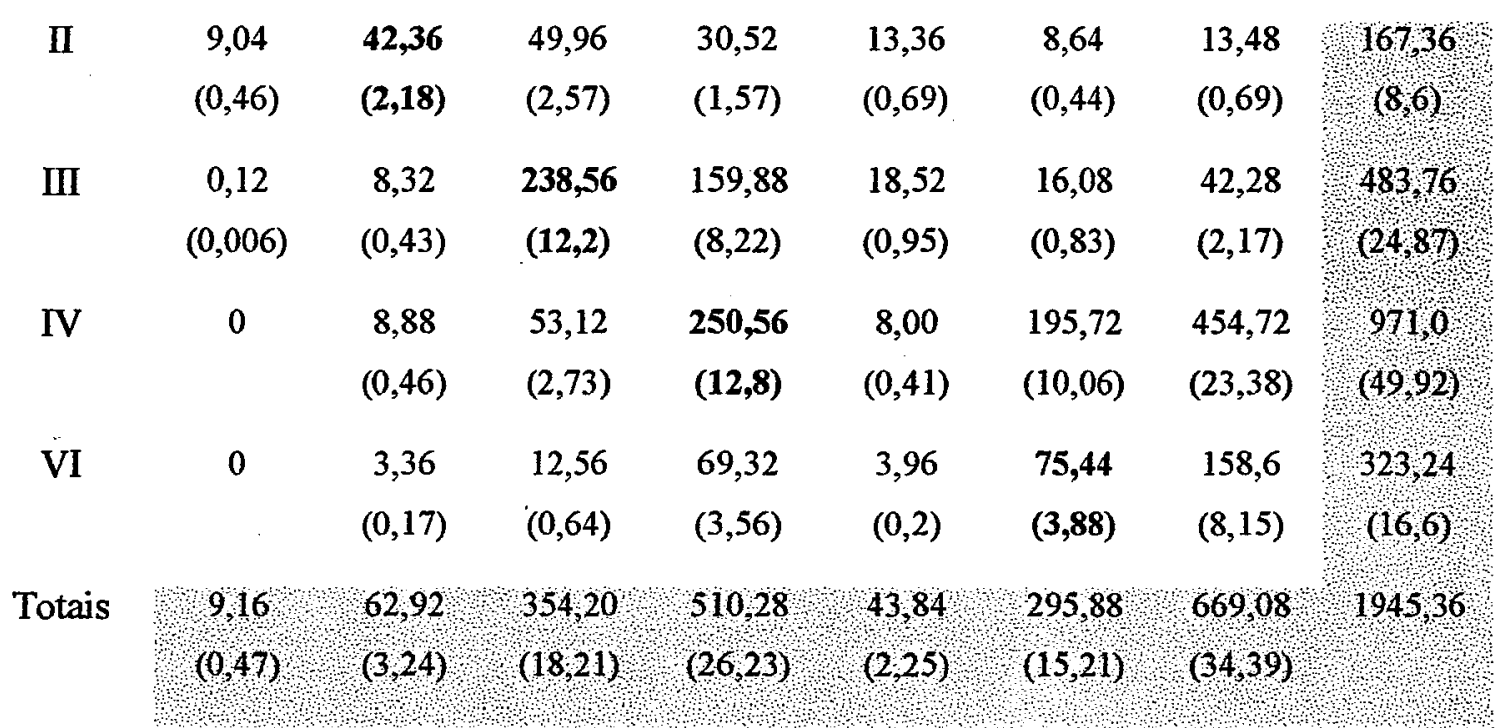

Observações: nesta matriz não constam as áreas urbanas e represas, perfazendo uma área de avaliação de 1945,36 ha.

$\mathrm{k}=0,31$ 
Tabela 14. Matriz de erros das áreas da relação entre a classificação da capacidade de uso das terras dos avaliadores 1 e 5 .

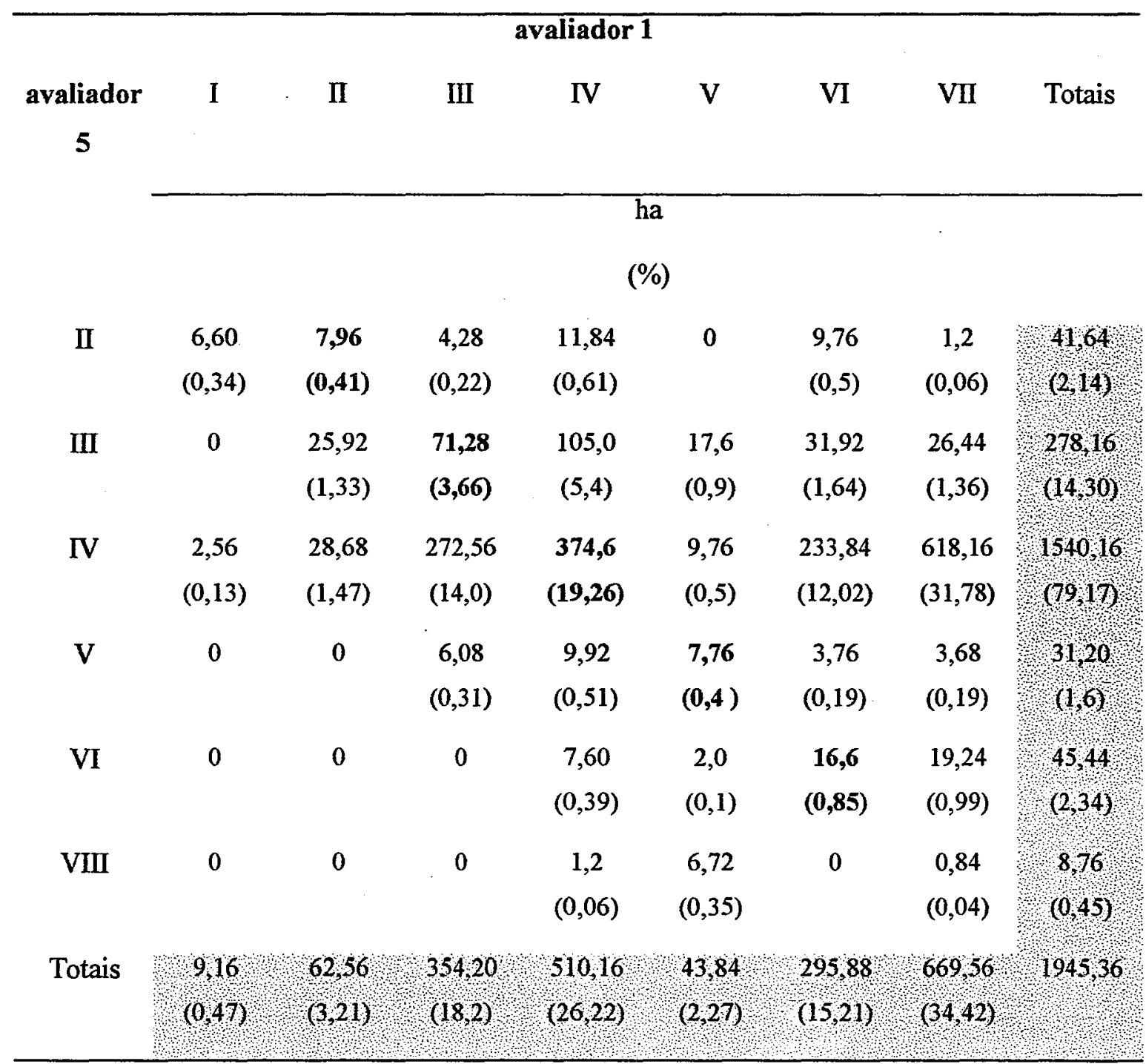

Observações: nesta matriz não constam as áreas urbanas e represas, perfazendo uma área de avaliação de 1945,36 ha.

$\mathbf{k}=0,25$ 
Tabela 15. Matriz de erros das áreas da relação entre a classificação da capacidade de uso das terras dos avaliadores 2 e 3 .

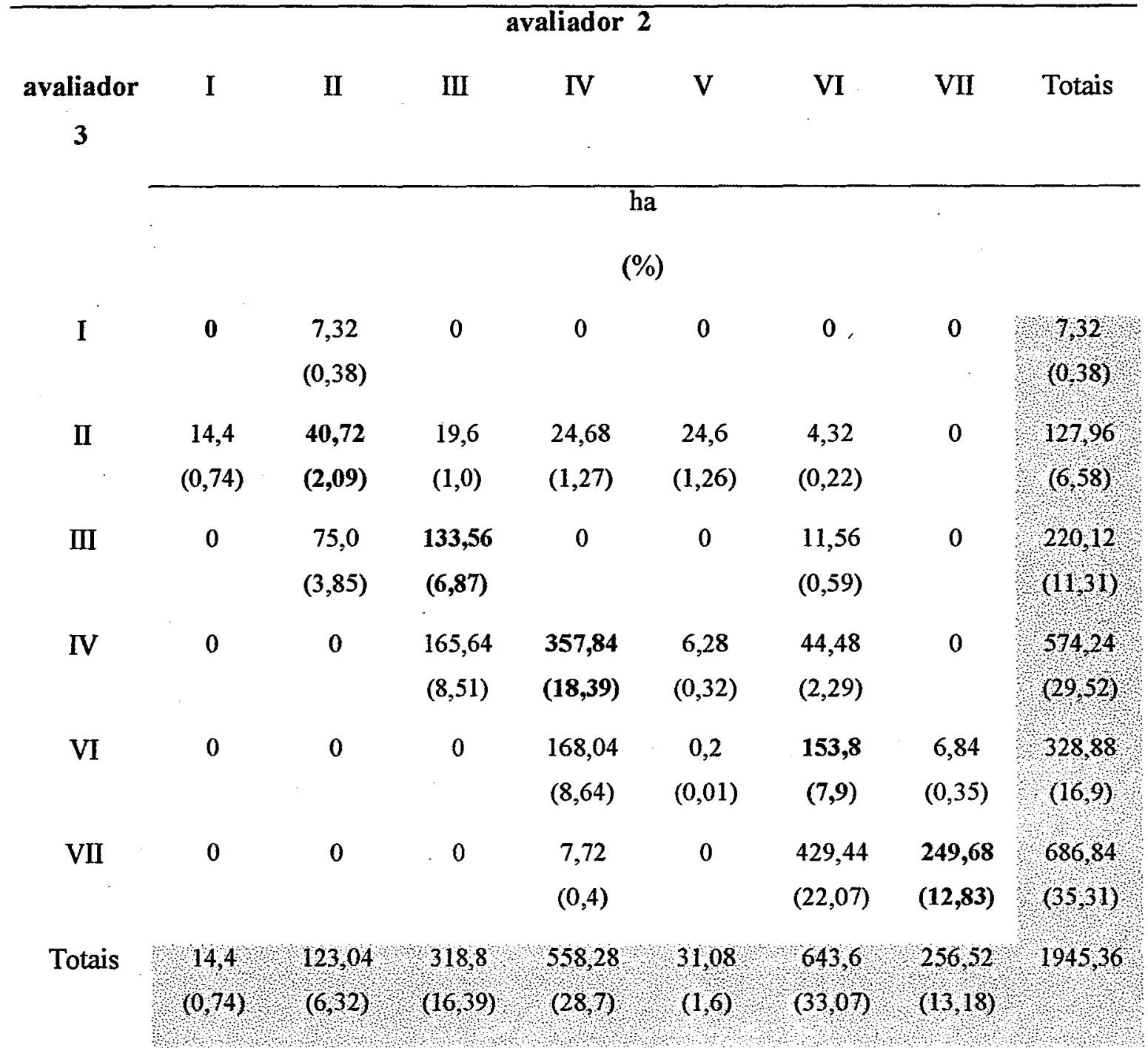

Observações: nesta matriz não constam as áreas urbanas e represas, perfazendo uma área de avaliação de 1945,36 ha.

$\mathrm{k}=0,48$ 
Tabela 16. Matriz de erros das áreas da relação entre a classificação da capacidade de uso das terras dos avaliadores 2 e 4 .

\begin{tabular}{|c|c|c|c|c|c|c|c|c|}
\hline \multicolumn{9}{|c|}{ avaliador 2} \\
\hline \multirow{3}{*}{$\begin{array}{c}\text { avaliador } \\
4\end{array}$} & I & II & III & IV & V & VI & VII & Totais \\
\hline & \multicolumn{8}{|c|}{ ha } \\
\hline & \multicolumn{8}{|c|}{$(\%)$} \\
\hline \multirow[t]{2}{*}{ II } & 12,84 & 48,8 & 52,24 & 31,2 & 5,88 & 14,84 & 1,2 & 1670 \\
\hline & $(0,66)$ & $(2,51)$ & $(2,68)$ & $(1,6)$ & $(0,3)$ & $(0,76)$ & $(0,06)$ & $(8,58)$ \\
\hline \multirow[t]{2}{*}{ III } & 0 & 30,08 & 155,04 & 189,52 & 17,2 & 80,28 & 11,52 & 483,64 \\
\hline & & $(1,55)$ & $(7,97)$ & $(9,74)$ & $(0,88)$ & $(4,1)$ & $(0,59)$ & $(24,86)$ \\
\hline \multirow[t]{2}{*}{ IV } & 1,04 & 39,96 & 100,52 & 277,24 & 4,4 & 430,96 & 117,36 & 971,48 \\
\hline & $(0,05)$ & $(2,05)$ & $(5,17)$ & $(14,25)$ & $(0,23)$ & $(22,15)$ & $(6,03)$ & $(499)$ \\
\hline \multirow[t]{2}{*}{ VI } & 0,16 & 4,2 & 11,0 & 60,32 & 3,6 & 117,52 & 126,44 & 32324 \\
\hline & $(0,008)$ & $(0,21)$ & $(0,56)$ & $(3,1)$ & $(0,19)$ & $(6,04)$ & $(6,5)$ & $(16,6)$ \\
\hline \multirow[t]{2}{*}{ Totais } & 1404 & 12304 & 318,8 & 558.28 & 31,08 & 643,6 & 256,52 & 194536 \\
\hline & $(0,72)$ & $(6,32)$ & $(16,39)$ & $(28,7)$ & $(1,6)$ & $(33,08)$ & $(13,18)$ & \\
\hline
\end{tabular}

Observações: nesta matriz não constam as áreas urbanas e represas, perfazendo uma área de avaliação de 1945,36 ha.

$k=0,26$ 
Tabela 17. Matriz de erros das áreas da relação entre a classificação da capacidade de uso das terras dos avaliadores 2 e 5 .

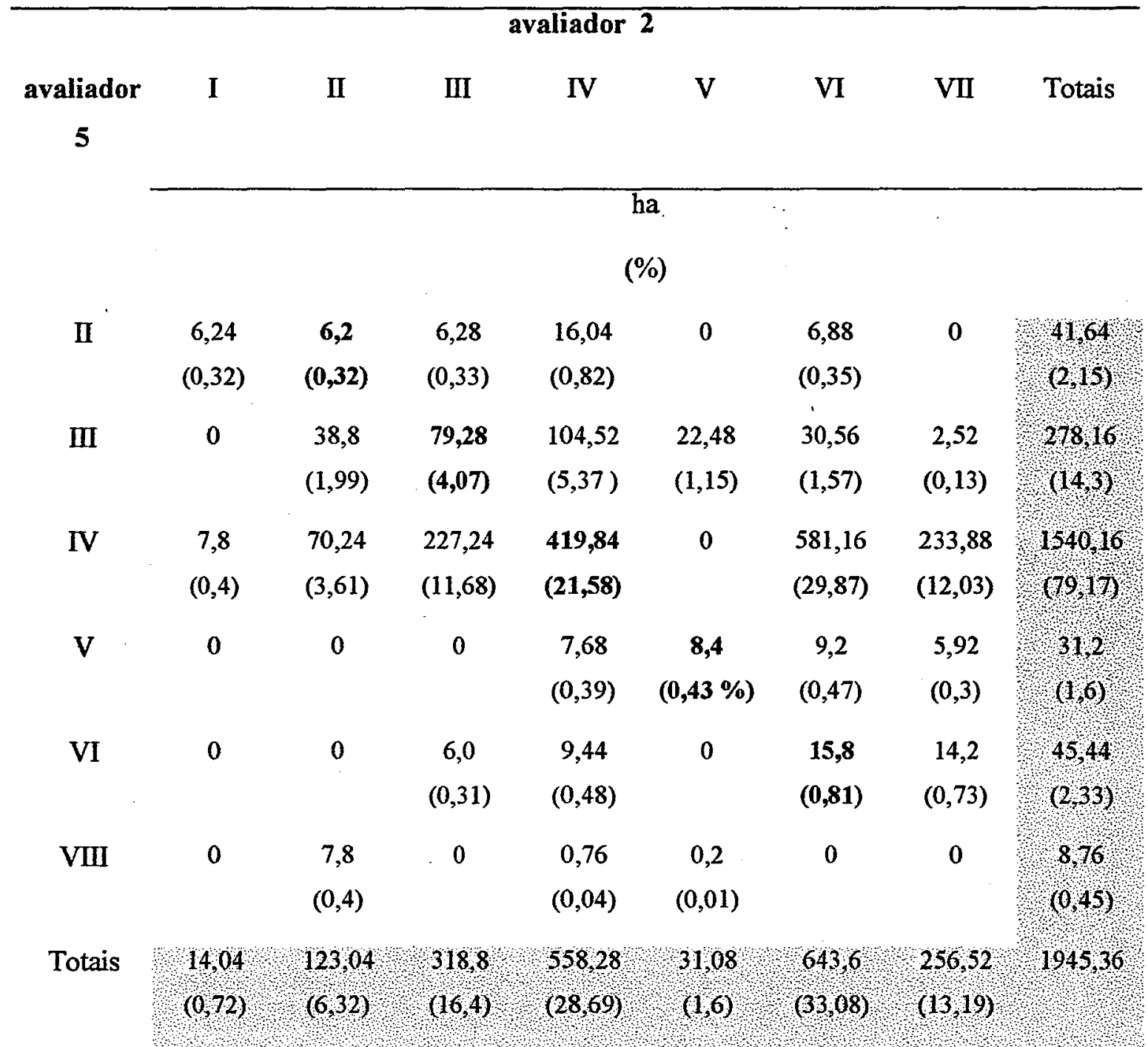

Observações: nesta matriz não constam as áreas urbanas e represas, perfazendo uma área de avaliação de 1945,36 ha.

$k=0,27$ 
Tabela 18. Matriz de erros das áreas da relação entre a classificação da capacidade de uso das terras dos avaliadores 3 e 4 .

\begin{tabular}{|c|c|c|c|c|c|c|c|}
\hline \multirow{3}{*}{$\begin{array}{c}\text { avaliador } \\
4\end{array}$} & \multicolumn{7}{|c|}{ avaliador 3} \\
\hline & I & II & III & IV & VI & VII & Totais \\
\hline & & & & $\begin{array}{l}\text { ha } \\
\text { (\%) }\end{array}$ & & & \\
\hline II & $\begin{array}{c}5,32 \\
(0,27)\end{array}$ & $\begin{array}{c}26,0 \\
(1,33 \%)\end{array}$ & $43,28(2,2)$ & $\begin{array}{l}54,44 \\
(2,8)\end{array}$ & $\begin{array}{l}27,64 \\
(1,42)\end{array}$ & $\begin{array}{l}10,32 \\
(0,54)\end{array}$ & $\begin{array}{l}167,0 \\
(8.58)\end{array}$ \\
\hline III & $\begin{array}{c}0,12 \\
(0,006)\end{array}$ & $\begin{array}{c}57,8 \\
(2,97 \%)\end{array}$ & $\begin{array}{l}74,88 \\
(3,85)\end{array}$ & $\begin{array}{l}195,36 \\
(10,04)\end{array}$ & $\begin{array}{l}114,52 \\
(5,89)\end{array}$ & $\begin{array}{l}40,96 \\
(2,1)\end{array}$ & $\begin{array}{l}483,64 \\
(24,86)\end{array}$ \\
\hline IV & $\begin{array}{l}1,88 \\
(0,1)\end{array}$ & $\begin{array}{c}38,68 \\
(1,99 \%)\end{array}$ & $\begin{array}{l}95,12 \\
(4,89)\end{array}$ & $\begin{array}{c}27948 \\
(14,37)\end{array}$ & $\begin{array}{c}112,84 \\
(5,8)\end{array}$ & $\begin{array}{l}443,48 \\
(22,8)\end{array}$ & $\begin{array}{r}97 \% 48 \\
(69,95)\end{array}$ \\
\hline VI & 0 & $\begin{array}{c}5,48 \\
(0,28)\end{array}$ & $\begin{array}{c}6,84 \\
(0,35)\end{array}$ & $\begin{array}{l}44,96 \\
(2,31)\end{array}$ & $\begin{array}{l}73,88 \\
(3,8)\end{array}$ & $\begin{array}{c}192,08 \\
(9,87)\end{array}$ & $\begin{array}{l}323,24 \\
(16,61)\end{array}$ \\
\hline Totais & $\begin{array}{l}7,32 \\
(0,38)\end{array}$ & $\begin{array}{l}127,96 \\
(6,57)\end{array}$ & $\begin{array}{l}220,12 \\
(11,31)\end{array}$ & $\begin{array}{l}574,24 \\
(29,52)\end{array}$ & $\begin{array}{l}328,88 \\
(16,91)\end{array}$ & $\begin{array}{l}686,84 \\
(35,31)\end{array}$ & 194536 \\
\hline
\end{tabular}

Observações: nesta matriz não constam as áreas urbanas e represas, perfazendo uma área de avaliação de 1945,36 ha.

$k=0,23$ 
Tabela 19. Matriz de erros das áreas da relação entre a classificação da capacidade de uso das terras dos avaliadores 3 e 5 .

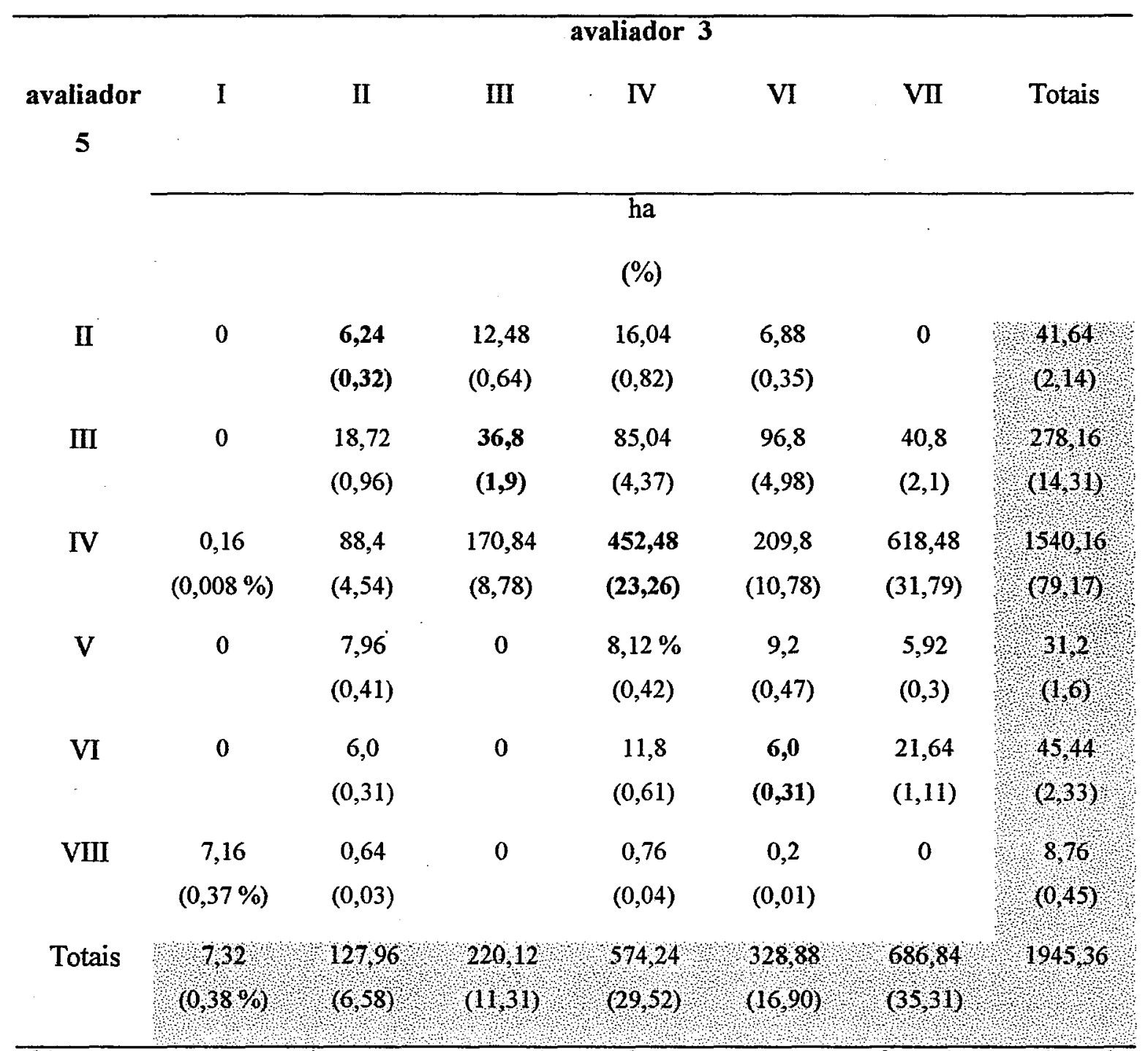

Observações: nesta matriz não constam as áreas urbanas e represas, perfazendo uma área de avaliação de 1945,36 ha.

$\mathrm{k}=0,26$ 
Tabela 20. Matriz de erros das áreas da relação entre a classificação da capacidade de uso das terras dos avaliadores 4 e 5 .

\begin{tabular}{|c|c|c|c|c|c|}
\hline \multirow{3}{*}{$\begin{array}{c}\text { avaliador } \\
5\end{array}$} & \multicolumn{5}{|c|}{ avaliador 4} \\
\hline & II & III & IV & VI & Totais \\
\hline & & & & & \\
\hline & \multicolumn{5}{|c|}{ ha } \\
\hline & \multicolumn{5}{|c|}{$(\%)$} \\
\hline II & $19,04(0,98)$ & $0,80(0,04)$ & $21,8(1,12)$ & 0 & $41,64(2,14)$ \\
\hline III & $46,16(2,37)$ & $142,28(7,31)$ & $49,76(2,56)$ & $39,96(2,05)$ & $27816(143)$ \\
\hline IV & $83,96(4,32)$ & $335,6(17,25)$ & $850,0(43,69)$ & $270,6(13,91)$ & $1540,2(79,17)$ \\
\hline V & $9,24(0,48)$ & $1,92\left(\begin{array}{ll}0 & 1\end{array}\right)$ & $16,28(0,84)$ & $3,76(0,19)$ & $31,20(1,6)$ \\
\hline VI & $2,28(0,12)$ & $3,04(0,16)$ & $31,20(1,6)$ & $8,92(0,47)$ & $45,44(2,34)$ \\
\hline VIII & $6,32(0,32)$ & 0 & $2,44(0,12)$ & 0 & $8,76(0,45)$ \\
\hline Totais & $1670(8,58)$ & $483,64(24,86)$ & $97148(49,94)$ & $323,24(16,62)$ & 1945,36 \\
\hline \multicolumn{6}{|c|}{ Observações: nesta matriz não constam as áreas urbanas e represas, perfazendo uma área de } \\
\hline & $\mathrm{k}=0,52$ & & & & \\
\hline
\end{tabular}

Os dados da tabela 11 mostraram a concordância entre as classificações dos avaliadores 1 e 2 , no que diz respeito à quantidade e classes utilizadas para enquadrar as terras da MHCC em classes de capacidade de uso. Ambos definiram as terras nas classes I, II, III, IV, V, VI e VII. A diagonal principal correspondente a concordância entre classes iguais, apresentou as maiores áreas para as classes I, II, III, IV e VI indicando que nestas classes houve maior número de áreas de concordância espacial. Nas classes V e VII observaram as maiores áreas de concordância uma classe acima daquelas relacionadas na diagonal principal. Esse tipo de alteração é conseqüência da 
variação ocorrida na interpretação dos critérios de avaliação do SCCUT. A qualidade da concordância, verificada pelo parâmetro $k=0,44$ foi considerada ruim.

A concordância espacial dos avaliadores 1 e 3, apresentadas na matriz de erros da tabela 12 , demonstrou primeiramente a não coincidência entre a quantidade e as classes de capacidade de uso utilizadas para identificar as terras da MHCC de acordo com a sua capacidade de uso. Enquanto o avaliador 1 utilizou as sete primeiras classes de capacidade de uso, o avaliador 3 usou dentre as classes escolhidas pelo avaliador 1 , apenas seis, excluindo a classe $\mathrm{V}$ e, no memorial descritivo, ainda indicou o uso da classe VIII para identificação das áreas de mata ou mata ciliar. De acordo com as áreas apresentadas na tabela 11 , a classe que apresentou maior índice de concordância foi a VII. A diagonal principal dessa matriz evidenciou a grande variação de interpretações dos critérios do SCCUT proporcionadas por avaliadores distintos. Isso foi observado pela presença das maiores áreas de concordância uma classe acima ou uma abaixo dos valores presentes na diagonal principal. Outra observação importante foi a total discordância das áreas que se referem à classe I. Sendo essa classe considerada como sem restrição de uso, os erros que incorrerem em sua determinação podem ser mais graves do que na determinação de outras classes. A qualidade de concordância avaliada pelo parâmetro $\mathrm{k}=0,43$ foi considerada ruim.

No processo de concordância entre os avaliadores 1 e 4, a matriz de erros (Tabela 13), apresentou uma discordância na quantidade e classes utilizadas na classificação da capacidade de uso das terras. A classificação de capacidade de uso das terras do avaliador 4 apresentou, dentre as sete classes utilizadas pelo avaliador 1 apenas quatro, tendo sido excluídas as classes I, V e VII. A matriz estando desfalcada provocou quebras no prolongamento da diagonal principal. Além disso a diagonal principal apresentou maior concordância apenas nas classes III e IV. O parâmetro $\mathrm{k}$ para essa concordância foi de 0,31 , indicando qualidade ruim

Pela tabela 14 observou-se, como na comparação anterior, quantidade e classes de capacidade diferentes entre os avaliadores 1 e 5 . O avaliador 5 não identificou nenhuma área como pertencente às classes I e VII utilizadas pelo avaliador 1 . Em 
contrapartida utilizou a classe VIII, inexistente na classificação do avaliador 1 , para a definição de algumas áreas. Outra observação foi a presença de áreas de concordância baixas na diagonal principal e classes adjacentes, com exceção da classe III cuja maior área foi verificada na sua relação com a classe superior mais próxima. Dentre as classes usadas a que demonstrou maior concordância espacial em área foi a classe IV. Seu parâmetro $k=0,25$, indicou uma péssima qualidade de concordância.

A concordância entre as classificações executadas pelos avaliadores 2 e 3 que consta da tabela 15 , demonstrou a não utilização do mesmo número de classes para a caracterização da área de estudo. O avaliador 2 utilizou seis classes de capacidade de uso, enquanto que o avaliador 3 usou cinco classes, sendo a classe $V$ a não utilizada por esse avaliador. As maiores concordâncias verificadas na diagonal principal da matriz de erros ficaram especificadas pelas classes IV, VI e VII. O resultado do parâmetro $k=0,48$ demonstrou que a qualidade de concordância foi ruim.

$\mathrm{Na}$ tabela 16 encontram-se os dados da matriz de erros da concordância entre as classificações de capacidade de uso das terras dos avaliadores 2 e 4 . Nessa análise, ficou bem evidente que o número de classes, diferenciadas em função do avaliador, prejudicaram a concordância espacial entre as classificações. Esse fato ficou bem claro na resposta do parâmetro $\mathrm{k}=0,26$ que evidencia uma péssima qualidade de concordância Das sete classes de capacidade de uso utilizadas pelo avaliador 2 , somente quatro foram necessárias para a classificação do avaliador 4 , ficando excluídas as classes I, V e VII. A melhor concordância pode ser verificada na classe IV.

A matriz de erros da concordância espacial dos avaliadores 2 e 5 (Tabela 17), mostrou que a maior concordância na diagonal principal, estava relacionada com a classe de capacidade de uso das terras IV. Além do avaliador 5 não ter utilizado as classes I e VII na determinação de sua classificação, verificou-se que houve uma variação considerável na escolha das classes. $\mathrm{O}$ parâmetro $\mathrm{k}$ para esta concordância foi de 0,27 , correspondendo a uma péssima qualidade de concordância. O mesmo ocorreu com a matriz de erros da tabela 18 que faz referência a concordância espacial das 
classificações de capacidade de uso das terras dos avaliadores 3 e 4 , cujo parâmetro $k$ foi de 0,23 .

A concordância espacial das classificações dos avaliadores 3 e 5, verificada na tabela 19, comprovou que as variações na determinação de classes de capacidade de uso das terras, são constantes. Enquanto o avaliador 3 não utilizou as classes de capacidade de uso das terras V e VIII para a sua classificação, o avaliador 5 não determinou nenhuma área pertencente à classe I. Como nas outras concordâncias, a maior área de concordância na diagonal principal foi verificada na classe IV. Ainda foi observada pouca concordância de grandes áreas com classes próximas a diagonal principal. A qualidade de concordância observada foi péssima, devido ao parâmetro $\mathrm{k}=0,26$.

A tabela 20, cuja matriz de erros refere-se a concordância entre as classificações dos avaliadores 4 e 5 , apresentou uma concordância razoável $(k=0,52)$ mesmo tendo o avaliador 4, utilizado um número menor de classes de capacidade de uso se comparado com o avaliador 5. Nesta matriz, a maior concordância em área, existente na diagonal principal, relacionou-se à classe IV.

Um resumo de todos os parâmetros $\mathrm{k}$ e suas qualificações, resultantes das matrizes de erros anteriormente apresentadas, encontram-se na tabela 21.

Tabela 21. Parâmetro $\mathrm{k}$ e qualidade de concordância para as concordâncias espaciais entre as classificações.

\begin{tabular}{lccccc}
\hline \multicolumn{5}{c}{ Avaliadores } \\
Avaliadores & 1 & 2 & 3 & 4 & 5 \\
\hline $\mathbf{1}$ & - & 0,44 (ruim) & 0,43 (ruim) & 0,31 (ruim) & 0,25 (péssima) \\
$\mathbf{3}$ & 0,44 (ruim) & - & 0,48 (ruim) & 0,26 (péssima) & 0,27 (péssima) \\
$\mathbf{3}$ & 0,43 (ruim) & 0,48 (ruim) & - & 0,23 (péssima) & 0,26 (péssima) \\
$\mathbf{5}$ & 0,31 (ruim) & 0,26 (péssima) & 0,23 (péssima) & - & 0,52 (razoável) \\
\hline
\end{tabular}


Na tabela 21 verificou-se, pela análise dos parâmetros $\mathrm{k}$ apresentados, que as qualidades das concordâncias variaram entre péssimas e boas. Com essa qualificação ficou bem evidente a presença de dois grupos distintos de avaliadores. As concordâncias entre as classificações de capacidade de uso das terras dos três primeiros avaliadores, forneceram parâmetros k relacionados a uma qualidade ruim. Quando as classificações destes foram confrontadas com as classificações dos avaliadores 4 e 5 , a qualidade de concordância tornou-se mais baixa, passando para péssima. Em contrapartida, as classificações dos avaliadores 4 e 5 , tiveram uma qualidade de concordância considerada razoável. Esse fato deveu-se à similaridade do perfil profissional existente entre os avaliadores 1,2 e 3 e entre os avaliadores 4 e 5 , criando uma tendência na interpretação dos critérios do SCCUT, baseadas em objetivos distintos.

Os resultados das concordâncias espaciais mostraram grande variação nas classificações de capacidade de uso das terras, reveladas pelos seus parâmetros $\mathrm{k}$ e pela existência de dois grupo de avaliadores, o grupo 1 composto pelos avaliadores 1,2 e 3, e o grupo 2 composto pelos avaliadores 4 e 5 que mostraram tendências de interpretação distintas para os critérios do SCCUT.

\subsubsection{Concordância global}

A concordância global refere-se à coincidência em área, das classes de capacidade de uso das terras, sem levar em consideração a sua localização dentro da MHCC. Para esta análise foram utilizadas as classificações dos sete avaliadores participantes.

As áreas dessas classificações bem como os resultados da análise estatística executada sobre esses dados, encontram-se na tabela 22. 
Tabela 22. Áreas e estatística das classificações da capacidade de uso das terras de todos os avaliadores.

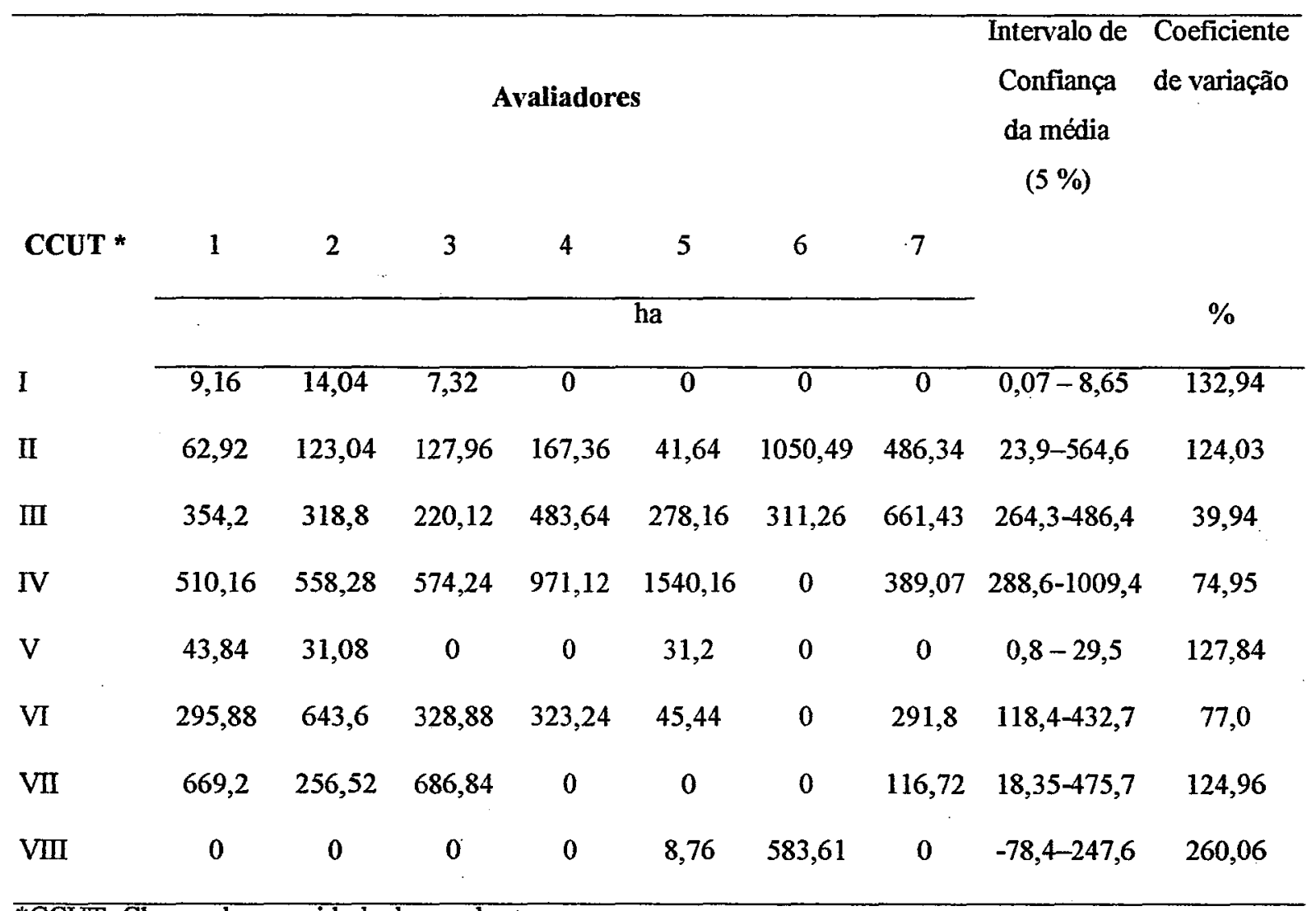

*CCUT: Classes de capacidade de uso das terras.

De acordo com os valores estatísticos apresentados na tabela 22, a variação nas classificações de capacidade de uso das terras ficou bem evidente. Extensa foi a amplitude dos intervalos de confiança da média foi extensa, demonstrando em termos probalísticos que os intervalos calculados a $95 \%$ contém o valor da média. Essa extensa amplitude deveu-se a grande variação das áreas de cada classe de capacidade de uso determinadas pelos avaliadores, bem como a existência de classes que não foram utilizadas por todos na avaliação.

O coeficiente de variação em ordem crescente, apresentou-se da seguinte forma: $39 \%$ (Classe III), $74 \%$ (Classe IV), $77 \%$ (Classe VI), $124 \%$ (Classe II), $124 \%$ (Classe VII), $127 \%$ (Classe V), $132 \%$ (Classe I) e $260 \%$ (Classe VIII). Verificou-se que a determinação das classes de capacidade de uso em função dos avaliadores, apresentou elevada variabilidade intrínseca em todas as classes. Verificou-se que houve uma 
tendência dos três primeiros avaliadores em usarem as mesmas classes de capacidade de uso, com exceção do avaliador 3 que não utilizou a classe $V$. Os avaliadores 4, 5, 6 e 7 foram unânimes na não utilização da classe I e na utilização da classe III, mas houve discordância na escolha das demais classes. A ausência de classes nas respostas de alguns avaliadores, colaboraram para o grande coeficiente de variação. Esse foi o principal motivo pelo qual as classes I, V, VII e principalmente a VIII tiveram coeficientes de variação altos. Em contrapartida, não foi a causa do coeficiente de variação de $124 \%$ da classe II. Nessa classe a variabilidade deu-se pela grande discrepância dos valores de área definidos para a classe, cuja amplitude foi de 62 ha para o avaliador 1 a 1.050 ha para o avaliador 6 .

Como houveram classes ausentes nas classificações de capacidade de uso das terras apresentadas, foram calculados novamente o intervalo de confiança da média e coeficiente de variação para aquelas classes não utilizadas por alguns avaliadores. Isso foi feito para a verificação do comportamento dos dados das classes I, IV, V, VI, VII e VIII. Esses dados encontram-se na tabela 23.

Os valores da tabela 23 demonstraram que as áreas das classes sendo calculadas sem os zeros, correspondentes às ausências nas classificações, tenderam a amplitudes do intervalo de confiança, bem como coeficientes de variação, menores do que aqueles encontrados na tabela 20 . 
Tabela 23. Áreas e estatística das classes de capacidade de uso das terras não utilizadas por todos os avaliadores.

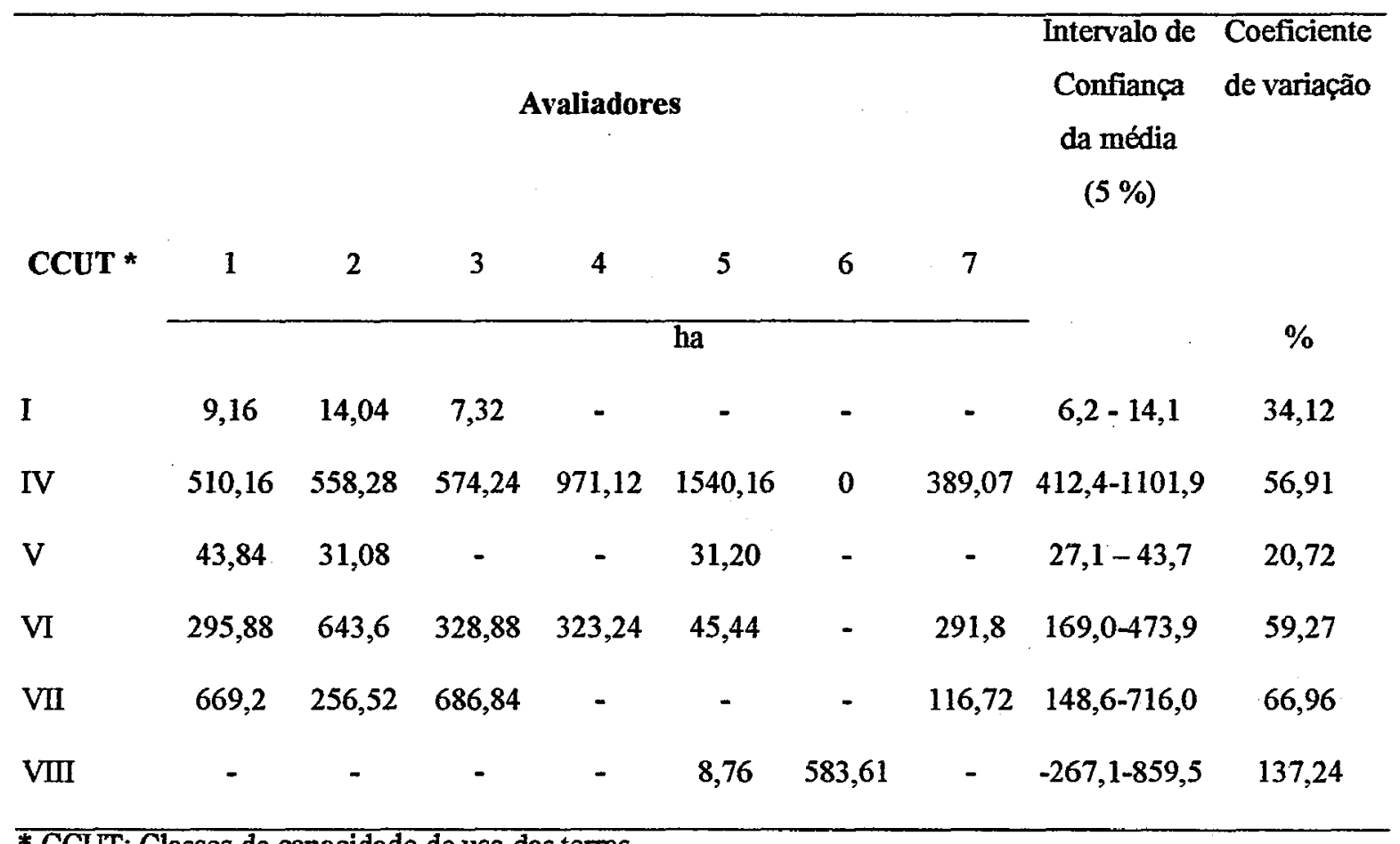

* CCUT: Classes de capacidade de uso das terras.

Os coeficientes de variação apresentaram-se, em ordem crescente, da seguinte forma: $20 \%$ (Classe V), $34 \%$ (Classe I), $56 \%$ (Classe IV), $59 \%$ (Classe VI) e $137 \%$ (Classe VIII). Verificou-se que os dados demonstram um coeficiente de variação para a classe $\mathrm{V}$ de $20 \%$, tendo diminuído expressivamente seu valor em relação daquele encontrado na tabela 22, o mesmo ocorrendo com as demais classes. Isso demonstra que os avaliadores que utilizaram a classe $\mathrm{V}$, concordaram no estabelecimento das áreas para esta classe, havendo pouca variação em relação à média. Mesmo seguindo igual tendência, a classe VIII ainda sofreu consequêencias relativas ao número pequeno de avaliadores que a utilizaram, apenas dois, e ao grande intervalo correspondente entre seus dados, permanecendo seu intervalo de confiança muito amplo e seu coeficiente de variação com um valor muito acima dos $100 \%$.

As concordâncias globais revelaram grande variação numérica entre as áreas definidas para cada classe de capacidade de uso. Esse fato ficou evidente mediante a 
observação da amplitude proporcionada pelo intervalo de confiança da média e pelo coeficiente de variação para cada classe. Isso ocorreu face ao número considerável de classes de capacidade de uso que não foram utilizadas principalmente pelos avaliadores 4, 5, 6 e 7, na classificação final da área. Na tentativa de minimizar esse efeito, recalculando o intervalo de confiança da média e o coeficiente de variação, sem a presença das classes ausentes que correspondiam a zero, verificou-se diminuição destes parâmetros, mas ainda permaneceram com uma considerável amplitude de variação. 


\section{CONCLUSÕES}

Pela análise geral das respostas obtidas no presente trabalho, chegou-se as seguintes conclusões:

1. Observou-se alta influência do avaliador sobre a variação das classificações de capacidade de uso das terras, tanto em relação às concordâncias espaciais como em relação às concordâncias globais. Isso foi conseqüência direta das múltiplas interpretações de seus usuários e dos inúmeros usos do SCCUT.

2. A variação intrínseca às classificações de capacidade de uso das terras foi suficientemente alta para que o SCCUT não seja recomendado como instrumento adequado para a maioria dos objetivos aos quais ele é aplicado, como valoração de terras, perícias imobiliárias e políticas de gestão ambiental. 


\section{CONSIDERAÇÕES FINAIS}

Pelas informações obtidas e observações feitas sobre o SCCUT e sua utilização no decorrer do presente trabalho, chegou-se as seguintes considerações:

1. O material gráfico para execução de avaliações, cuja a finalidade é prática como trabalhos de planejamento agrícola, deve ser criteriosamente escolhido. O mapa de classes de declividade gerado manualmente mostrou-se mais adequado como um dos materiais base para a definição das classes SCCUT, do que o gerado pelo SIG Idrisi.

2. Os mapas pedológicos e de classes de declividade mostraram-se obrigatórios na definição das classes de capacidade de uso das terras, pelos colaboradores participantes. Observação de detalhes a campo, através de visitas a área de estudo, foram dispensados, mesmo sendo prerrogativa na definição de trabalhos ligados a planejamento agrícola.

3. A maior parte dos usuários do SCCUT, não tem domínio completo sobre as informações de sua metodologia. As pressuposições básicas sobre a utilização da metodologia do SCCUT, constantes no capitulo 3 do Manual para Levantamento Utilitário do Meio Físico e Classificação de Terras no Sistema de Capacidade de Uso, não estão sendo consultadas pelos seus usuários, incorrendo em aplicações a que não foi originalmente destinado ${ }^{2}$

5. O SCCUT, não é apropriado e nem mesmo foi elaborado, para atender o objetivo da valoração de terras. Segundo Lepsch et al. (1991), distâncias de mercados, tipos de estradas, tamanho de glebas, localização em função das demais áreas, não são critérios para a classificação da capacidade de uso.

${ }^{2}$ LEPSCH, I. F. (Universidade Federal de Uberlândia). Comunicação pessoal, 1998. 
Pelas conclusões obtidas e considerações finais apresentadas, há a necessidade de minimizar os problemas relacionados ao SCCUT, com relação a forma como apresentase a sua metodologia:

a) reformulação do manual que contém a metodologia do SCCUT, dando maior enfoque nas pressuposições básicas e definindo de forma mais direta as diferenças entre classes, através da colocação de definições objetivas nos termos que diferenciam as classes de capacidade de uso das terras,

b) elaboração de manuais direcionados às especificidades ambientais de cada região do Brasil,

c) elaboração de manuais direcionados a avaliação de terras para os objetivos específicos à que está sendo utilizado o SCCUT, como valoração de terras e perícia imobiliária,

d) criação de um manual geral que proporcione sua utilização conforme a necessidade de avaliação do usuário, ou seja, indicando quais os parâmetros a serem avaliados de acordo com o objetivo a ser alcançado. 


\section{REFERÊNCIAS BIBLIOGRÁFICAS}

ALVES, L. M. Sistemas de Informação Geográfica. In: SIMPÓSIO BRASILEIRO DE GEOPROCESSAMENTO, 1., São Paulo, 1990. Anais. São Paulo: USP, Escola Politécnica, 1990. p. 66-78.

ASSAD, M. L. L. Uso de um sistema de informações geográficas na determinação da aptidão agrícola das terras. Revista Brasileira de Ciência do Solo, v.19, n.1, p. 133$139,1995$.

ASSUNÇÃO, G. V.; FORMAGGIO, A. R.; ALVES, A. R. Mapa de aptidão agrícola das terras e uso adequado das terras: uma abordagem usando o SGI e imagens de satélite. In: SIMPÓSIO BRASILEIRO DE SENSORIAMENTO REMOTO, 6., Manaus, 1990. Anais. São José dos Campos: INPE, 1990. p. 162-166.

BEEK, K. L. Land evaluation for agricultural development. Wageningen, International Institute for Land Reclamation and Improvement, 1978. 333p. (ILRI. Publication, 23)

BRASIL. Conselho Nacional do Meio Ambiente. Resoluções do CONAMA 1984/91. 4. ed. Brasília: IBAMA, 1992. 245p.

BRASIL. Ministério da Agricultura, do Abastecimento e Reforma Agrária. Instituto Nacional de Colonização e Reforma Agrária. Diretoria de Assuntos Fundiários. Sistemática de desapropriação por interesse social. Brasília, 1993. 46p. (Instrução Normativa, 8) 
BUOL, S. W.; SANCHEZ, P. A.; CATE Jr, R. B.;GRANGER, M. A. Classificación de suelos en base a su fertilidad. In: ALVARADO, A.; BORNEMISZA, E. Manejo de suelos en la America Tropical. Raleigh: North Caroline, State University, 1974. p. 129-144.

BURROUGH, P. A. Principles of geographical information systema for land resources assessment. Oxford: Claredon Press, 1986. 193p.

CARTER, V. H. Classificacão de terras para irrigação. Brasília: Secretaria de Irrigação, 1993. 208p.

CASALINHO, H. D; BOURSCHEID, C. A. Avaliação da capacidade de uso da terra em área de assentamento no centro agropecuário da Palma, UFPEL, RS (compact disc). In: CONGRESSO LATINO-AMERICANO DE CIENCIA DO SOLO, 13., Águas de Lindóia, 1996. Solo-suelo 96: trabalhos. Piracicaba: SBCS/SLCS, 1996.

CHRISTOFOLETTI, A. (Coord.). Bacias hidrográficas como unidade de estudo. In: WORKSHOP DO PROJETO PIRACENA, Nazaré Paulista, 1996. Anais. Piracicaba: CENA, 1996. p. 171-173.

CONGALTON, R. G.; ODERWALD, R. G.; MEAD, R. A. Assessing landsat classification accuracy using discrete multivariate analysis statistical techniques. Photogrametric Engineering and Remote Sensing, v.49, n.12, p. 1671-1678, 1983.

DEMÉTRIO, A. V. Curso de engenharia de avaliação de perícias agronômicas: conceituação geral e exemplos. Piracicaba: FEALQ, 1995. 201p.

EASTMAN, J. R. Idrisi: user's guide. Worcester: Clark University, 1992.

FAO. A framework for land evaluation. Rome, 1976. 72p. (Soil Bulletin, 32; ILRI. Publication, 22) 
FIORIO, P. R. Cronologia do uso da terra e seu impacto no ambiente da Microbacia Hidrográfica do Córrego do Ceveiro da região de Piracicaba, SP. Piracicaba, 1998. 107p. Dissertação (Mestrado) - Escola Superior de Agricultura "Luiz de Queiroz", Universidade de São Paulo.

FRANÇA, G. V. Interpretação de levantamentos de solos: classificações técnicas ou interpretativas. Piracicaba: ESALQ, 1980a. 28p.

FRANÇA, G. V. Interpretação de levantamentos de solos para fins conservacionistas. Piracicaba: ESALQ, 1980b. 35p.

GRIFFITH, J. J.; JUCKSCH, I.; DIAS, L. E.; CÂMARA, J. B. D.; ARRUDA, M. B. Incorporação de decisões comunitárias sobre zoneamento usando a análise Gestalt da paisagem. In: CONGRESSO BRASILEIRO DE UNIDADES DE PRESERVAÇÃO, Curitiba, 1997. Anais. Curitiba: IAP; UNILIVRE; Rede Nacional Pró Unidade de Conservação, 1997. v. 2, p. 119-136.

HELMS, D. Land capability: the US experience. History of Soil Science, v.19, p. 159-175, 1997.

HUDSON, N. Soil conservation. New York: Cornell University Press, 1971. 302p.

INSTITUTO DE PESQUISAS TECNOLÓGICAS DO ESTADO DE SÃO PAULO. Mapa geológico do Estado de São Paulo. São Paulo, 1981a. v.1, 126p. Escala 1:50.000. (IPT. Monografia, 6)

JENKINS, A.; PETERS, N.E.; RODHE, A. Hydrology. In: MOLDAN, B.; CERNY, J. (Coord.) Biogeochemistry of small catchments: a tool for environmental research. (Scope 51). Chichester: John Wiley, 1994. p. 31-54.

KLINGEBIEL, A. A.; MONTGOMERY, P. H. Land - capability classification. Washington: USDA, Soil conservation Service, 1961. 21p. (USDA. Handbook, 210)

LANDIS, J. R.; KOCH, G. G. The measurement of observer agreement for categorial data. Biometrics, v.33, p. 159-174, Mar. 1977. 
LEPSCH, I. F.; BELLINAZZI Jr., R.; BERTOLINI, D.; ESPINDOLA, C. R. Manual para levantamento utilitário do meio físico e classificação de terras no sistema de capacidade de uso. Campinas: Sociedade Brasileira de Ciência do Solo, 1983. $154 p$.

LEPSCH, I. F.; BELLINAZZI Jr., R.; BERTOLINI, D.; ESPÍNDOLA, C. R. Manual para levantamento utilitário do meio físico e classificação de terras no sistema de capacidade de uso. Campinas: Sociedade Brasileira de Ciência do Solo, 1991. $175 \mathrm{p}$.

LEPSCH, I. F.; SARAIVA, I. R.; DONZELLI, P. L.; MARINHO, M. A.; SAKAI, E.; GUILLAUMON, J. R.; PFEIFER, R. M.; MATTOS, I. F. A.; ANDRADE, W. J.; SILVA, C. E. F. Macrozoneamento das terras da região do Rio Ribeira de Iguape, SP. Campinas: IAC, 1990. 181p.

MARQUES, J. Q. A. (Coord.) Manual brasileiro para levantamento da capacidade de uso da terra. : Rio de Janeiro: Escritório Técnico Brasil - Estados Unidos, 1971. $433 p$.

MELLEROWICZ, K. T.; REES, H. W.; CHOW, T. L.; GHANEM, I. Soil conservation planning at watershed level using the Universal Soil Loss Equation with GIS and microcomputer technologies: a case study. Journal of Soil and Water Conservation, v. 49, n. 2, p. 194-199, Mar./Apr. 1994.

MOLDAN, B.; CERNY, J. Small catchment research. In: MOLDAN, B.; CERNY, J., (Coord.) Biogeochemistry of small catchments: a tool for environmental research. (Scope 51). Chichester: John Wiley, 1994. p. 1-29.

NAKAMA, V. Sistema de classificación de tierras por su capacidad de uso (USDA) con respecto al esquema de evaluación de tierras propuesto por FAO. Buenos Aires: Castelar, 1984. 24p.

NOGUEIRA, M. C. S. Estatística experimental aplicada à experimentação agronômica. Piracicaba: ESALQ, Depto. de Matemática e Estatística, 1997. 250p. 
ORTIZ, M. J. Integração de sensoriamento remoto, sistema de informações geográficas e banco de dados, na identificação de culturas agrícolas de inverno. São José dos Campos, 1993. 141p. Dissertação (M. S.) - Instituto Nacional de Pesquisas Espaciais.

PONZONI, J. F.; ALMEIDA, E. S. A estimativa do parâmetro Kappa (k) da análise multivariada discreta no contexto de um SIG. In: SIMPÓSIO BRASILEIRO DE SENSORIAMENTO REMOTO, 8., Salvador, 1996. São José doa Campos: INPE; SELPER, 1996.

PRADO, $\mathrm{H}$. do. Manual de classificação de solos do Brasil. 3. ed. Jaboticabal: FUNEP, 1996. 194p.

RAMALHO FILHO, A.; BEEK, K. J. Sistema de avaliação da aptidão agrícola das terras. 3 ed. Brasilia: SUPLAN; EMBRAPA,SNLCS, 1995. 65p.

RAMALHO FILHO, A.; PEREIRA, E. G.; BEEK, K. J. Sistema de avaliação da aptidão agrícola das terras. Brasilia: SUPLAN; EMBRAPA, SNLCS, 1978. 70p.

RANIERI, S. B. L. Avaliação de métodos e escalas de trabalho para determinação de risco de erosão em bacia hidrográfica utilizando sistema de informações geográficas (SIG). São Carlos, 1996. 129p. Dissertação (M. S.) - Escola de Engenharia de São Carlos - USP.

ROCHA, J. S. M. Manual de manejo integrado de bacias hidrográficas. Santa Maria: Universidade Federal de Santa Maria, 1991. 81p.

SANCHEZ, P. A.; COUTO, W.; BUOL, S. W. The fertility capability soil classification system: interpretation, applicability and modification. Geoderma, v.27, n. 4, p. 283$309,1982$.

SILVA, G. M. da. Avaliação de terras para o desenvolvimento rural, com o apoio do enfoque de sistemas, no município de Campo do Tenente - PR. Curitiba, 1993. 195p. Dissertação (M.S.) - Universidade Federal do Paraná.

STEELE, J. G. Soil surveys interpretation and its use. Rome: FAO, 1967. 68p. (FAO. Soils Bulletin 8) 
VALENTE, O. F. Manejo de bacias hidrográficas. Saneamento, v.50, n.2, p. 104-109, abr./jun. 1976. 